DIOGO BRANDAU SIGNORETTI

A UTILIZAÇÃO DE PRECEDENTES ESTRANGEIROS PELO SUPREMO TRIBUNAL FEDERAL: FUNDAMENTOS E CRITÉRIOS

DISSERTAÇÃO DE MESTRADO

ORIENTADOR: PROFESSOR DOUTOR ROGER STIEFELMANN LEAL

UNIVERSIDADE DE SÃO PAULO

FACULDADE DE DIREITO

SÃO PAULO - 2013 
DIOGO BRANDAU SIGNORETTI

\title{
A UTILIZAÇÃO DE PRECEDENTES ESTRANGEIROS PELO SUPREMO TRIBUNAL FEDERAL: FUNDAMENTOS E CRITÉRIOS
}

\author{
Dissertação de Mestrado apresentada à \\ Faculdade de Direito da Universidade de São \\ Paulo (FD/USP), como requisito para obtenção \\ do título de Mestre, na área de Direito do \\ Estado, subárea de Direito Constitucional, sob a \\ orientação do Prof. Dr. Roger Stiefelmann Leal.
}

\section{UNIVERSIDADE DE SÃO PAULO \\ FACULDADE DE DIREITO \\ SÃO PAULO - 2013}


BANCA EXAMINADORA: 


\section{AGRADECIMENTOS}

Primeiramente gostaria de agradecer minha família, em especial, meu pais, Hugo e Marta, pelo incentivo aos estudos e por sempre me propiciarem condições para que eu desenvolvesse todas as minhas capacidades intelectuais. Certamente sem ajuda e o suporte deles eu não teria chegado tão longe. Mas não seria justo e correto que eu apenas agradecesse pelo apoio na esfera educacional da minha vida. Mais do que agradecer por isso, eu gostaria de usar este espaço para demonstrar a gratidão que tenho pelos meus genitores por todo amor que me deram, pois é somente por sermos alimentados pelo amor que aprendemos a viver nossa vida com alegria, dando-lhe sentido. É justamente o que nos torna humano.

Em segundo lugar, agradeço ao meu orientador, Prof. Dr. Roger S. Leal, por ter me acolhido sob sua orientação, sendo extremamente atencioso desde o primeiro momento. Sou-lhe grato pelo tempo dispendido para me orientar e pela paciência que sempre teve para explicar e discutir os mais variados temas jurídicos. Mas mais do que isso tudo, me sinto extremamente privilegiado e contente por ter tido a oportunidade de conviver e aprender muito com este jovem professor. Espero que possamos manter o contato.

Em terceiro lugar, à minha esposa, Tessa, por todo apoio, paciência e compreensão, principalmente na fase final do mestrado, meu muito obrigado!

Por fim, gostaria de agradecer meus amigos.

Meu caro Esdras, grande amigo, colega de trabalho e de todas as etapas do mestrado, desde o processo de seleção até a finalização da dissertação, obrigado pelas horas de conversa e discussões jurídicas, pelo ajuda nas aulas, nas reuniões, nas monitorias e, finalmente, por dividir comigo as dificuldades e angustias de criar uma dissertação de mestrado.

Também gostaria de registrar meus agradecimentos a Marcia Matsuda Canholi, Bruno Cassiolato, Camila Nucci, Marina Miura e Karina Drummond, todos amigos que de alguma forma me ajudaram na elaboração deste trabalho. 


\section{DEDICATÓRIA}

Für meine Frau Tessa, für unsere einzigartige Liebe,

Diogo

\section{DEDICATION TO MY WIFE}

To whom I owe the leaping delight

That quickens my senses in our wakingtime

And the rhythm that governs the repose of our sleepingtime,

The breathing in unison

Of lovers whose bodies smell of each other

Who think the same thoughts without need of speech

And babble the same speech without need of meaning.

No peevish winter wind shall chill

No sullen tropic sun shall wither

The roses in the rose-garden which is ours and ours only

But this dedication is for others to read:

These are private words addressed to you in public.

(T.S. Eliot) 


\section{RESUMO}

A presente dissertação tem por objetivo analisar a utilização de precedentes estrangeiros pelo Supremo Tribunal Federal no controle de constitucionalidade. O uso de direito constitucional comparado pela jurisdição constitucional com o intuito de solucionar casos domésticos tem aumentado progressivamente e se tornou algo corriqueiro. Vários nomes surgiram para denominar o fenômeno: fertilização cruzada, empréstimos constitucionais, diálogo constitucional, migração de ideias constitucionais, interlocução constitucional, entre outros. No entanto, a difusão desta prática não veio acompanhada de uma reflexão acerca seus fundamentos e dos possíveis critérios e método que possam norteá-la. Logo, o presente trabalho focou-se justamente nesta problemática, analisando os argumentos prós e contra o uso de julgados estrangeiros na solução de controvérsias constitucionais, descrevendo as diversas formas de uso encontradas, sugerindo critérios e método para utilização legítima dos precedentes estrangeiros no âmbito da jurisdição constitucional. Por fim, este estudo voltou-se para uma análise da jurisprudência do Supremo Tribunal Federal com base nos parâmetros estabelecidos.

PALAVRAS-CHAVE: jurisdição constitucional - precedentes estrangeiros - método de interpretação constitucional - direito constitucional comparado - análise jurisprudencial 


\begin{abstract}
This paper aims to analyze the use of foreign precedents in constitution adjudication (judicial review) by the Brazilian Supreme Court. The use of comparative constitutional law by the constitutional jurisdiction for the purpose of resolving domestic cases has progressively increased and became commonplace. Several names are being used to describe the phenomenon, among others: cross-fertilization, constitutional borrowing, constitutional dialogue, migration of constitutional ideas and constitutional engagement. However, the increase of this practice has not been accompanied by a reflection on its theoretical justifications and on the possible criteria and method that can guide it. Consequently, this paper focuses on the above mentioned phenomenon by examining the arguments for and against the use of foreign precedent in constitutional decision-making, describing the various modes of use and suggesting criteria and method for legitimate use of foreign precedents within the constitutional jurisdiction. The study finalizes with an analysis of the jurisprudence of the Brazilian Supreme Court based on established parameters.
\end{abstract}

KEYWORDS: constitutional jurisdiction - foreign precedents - method of constitutional interpretation - compared constitutional law - judicial review 


\section{SUMÁRIO}

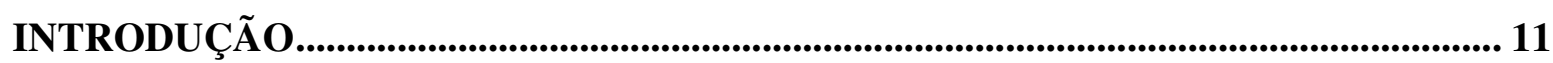

1 O DIREITO ESTRANGEIRO COMO FONTE DO DIREITO CONSTITUCIONAL:

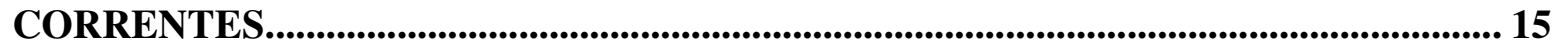

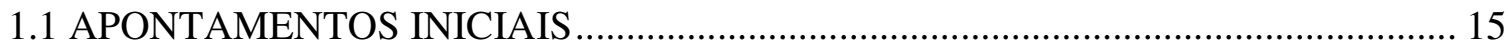

1.2 A VISÃO DO DIREITO COMPARADO E O OBJETO DESTE TRABALHO: OS TERMOS TRANSPLANTES LEGAIS E EMPRÉSTIMOS CONSTITUCIONAIS VERSUS O CONCEITO DE MIGRAÇÃO DE IDEIAS CONSTITUCIONAIS ............... 26

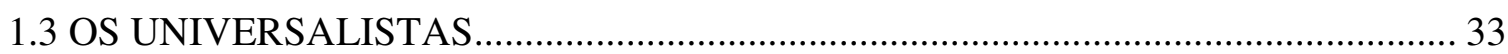

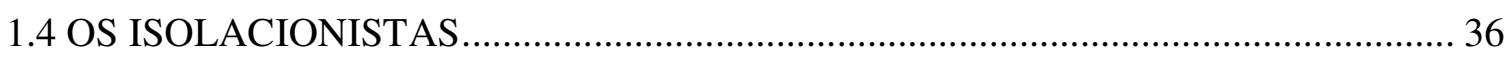

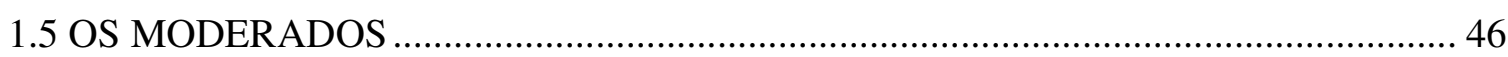

1.6 DIREITOS HUMANOS E O DIREITO MATERIAL COMUM NÃO ESCRITO: A EXISTÊNCIA DE UM SISTEMA INTERNACIONAL DOS DIREITOS HUMANOS E DE UMA CONSTITUIÇÃO MATERIAL NÃO ESCRITA COMO FUNDAMENTO PARA A UTILIZAÇÃO DE PRECEDENTES ESTRANGEIROS ..................................... 51

1.7 FUNDAMENTOS PARA A UTILIZAÇÃO DE PRECEDENTES ESTRANGEIROS 56 2 MODELOS DE UTILIZAÇÃO DOS PRECEDENTES ESTRANGEIROS .................. 60

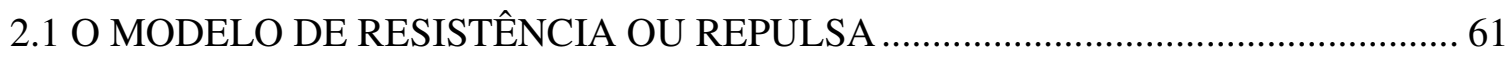

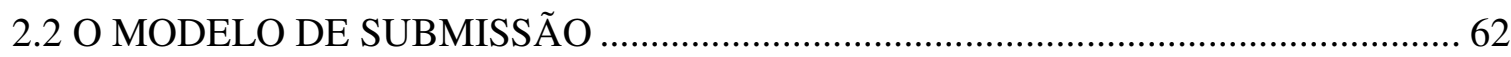

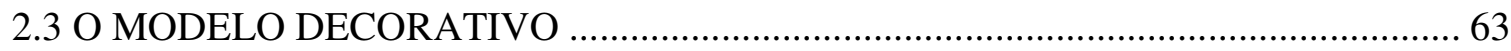

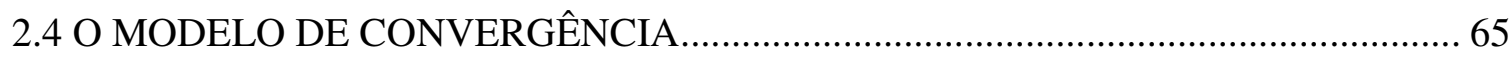

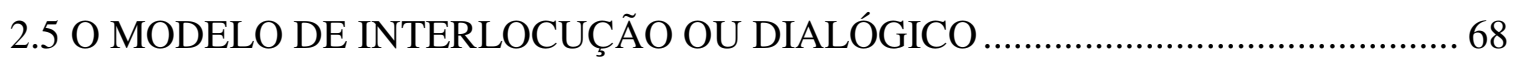

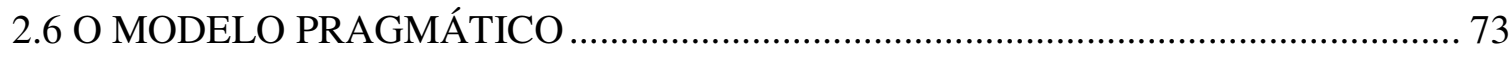

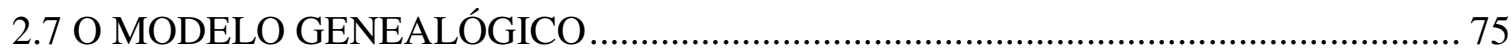

2.8 O MODELO ALEATÓRIO OU DE BRICOLAGEM ................................................ 76

3 CRITÉrios E MÉtodo PARA A UTILIZAÇÃo DE PRECEDENTES

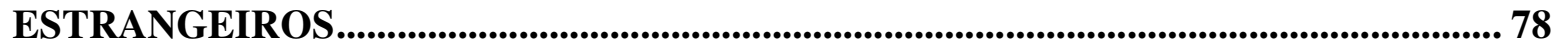

3.1 PRELIMINARMENTE: NECESSIDADE DE PREVISÃO CONSTITUCIONAL OU

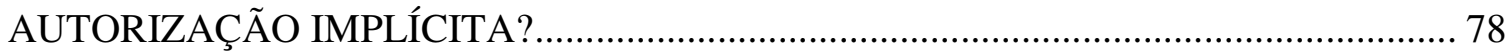


3.2 O PONTO DE PARTIDA: O TEXTO CONSTITUCIONAL DOMÉSTICO E SUA ABERTURA.

3.3 A QUESTÃO DO CONSENSO MUNDIAL, O PROBLEMA DA SELETIVIDADE DE FONTES ESTRANGEIRAS E DAS CORTES ELEGÍVEIS. 83

3.4 AS ÁREAS EM QUE SE PODE UTILIZAR O PRECEDENTE ESTRANGEIRO: APENAS O USO PRAGMÁTICO OU TAMBÉM NAS QUESTÕES JURÍDICOMORAIS? 91

3.5 O USO DE PRECEDENTES ESTRANGEIROS PAUTADOS PELO CRITÉRIO DA PRIMAZIA DO PRINCÍPIO HUMANO MAIS BENÉFICO E PELA EXPANSÃO DOS DIREITOS HUMANOS 95

3.6 OS CRITÉRIOS PARA REALIZAÇÃO DA COMPARAÇÃO: OS ELEMENTOS DE CONEXÃO ENTRE O CASO DOMÉSTICO E OS PRECEDENTES ESTRANGEIROS.99

3.6.1 A relação histórica entre países 102

3.6.2 As influências estrangeiras na feitura e reforma da constituição e a importação de legislação 106

3.6.3 Questões empíricas. 108

3.6.4 Valores Comuns 110

3.6.5 O uso negativo 111

3.6.6 Critérios: síntese conclusiva. 113

3.7 AS FORMAS DE UTILIZAÇÃO DOS PRECEDENTES ESTRANGEIROS. 114

3.7.1 A demonstração do $(s)$ elemento $(s)$ de conexão 115

3.7.2 A contextualização. 116

3.7.3 A pertinência: a possibilidade de adoção do precedente estrangeiro. 118

3.7.Sintese das etapas para a utilização de precedentes estrangeiros. 120

4 PRECEDENTES ESTRANGEIROS NA JURISDIÇÃO DO SUPREMO TRIBUNAL FEDERAL 122

4.1 HISTÓRICO E PANORAMA NORMATIVO E JURISPRUDENCIAL BRASILEIROS 122

4.2 O CASO ELLWANGER (HC 82.424). 129

4.3 O CASO DO ABORTO DE FETO COM ANENCEFALIA (ADPF 54) - O VOTO DO MINISTRO GILMAR MENDES 


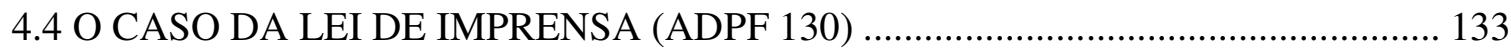

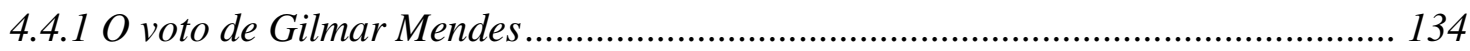

4.4.2 O voto de Celso de Mello ....................................................................................... 140

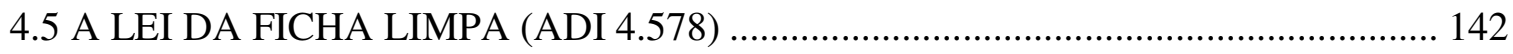

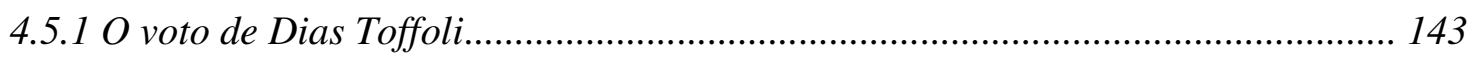

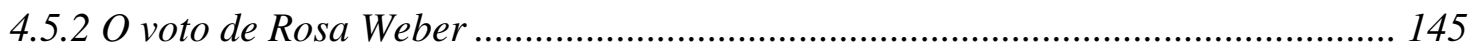

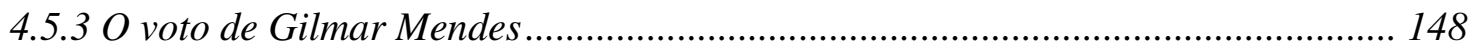

4.6 O CASO DAS COTAS (RESERVAS DE VAGAS) PARA AS UNIVERSIDADES PÚBLICAS (ADPF 186) - O VOTO DO RELATOR MINISTRO RICARDO

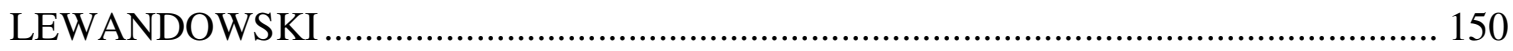

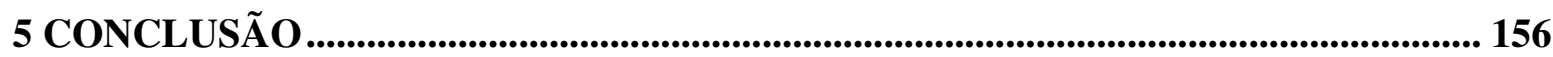

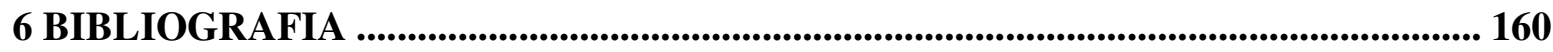




\section{INTRODUÇÃO}

A internacionalização do direito constitucional é assunto atual que tem sido objeto de inúmeros estudos ${ }^{1}$ que apontam uma mudança na maneira como os atores jurídicos lidam com elementos internacionais e estrangeiros que afetam a forma de aplicar o direito, no caso, o direito constitucional.

No que tange às cortes Constitucionais e às supremas cortes, uma das facetas desta internacionalização é a troca de informações e a utilização da experiência estrangeira para solucionar problemas jurídicos domésticos. Assim, a citação e menção a direito e precedentes estrangeiros tem se tornado, de certa forma, algo corriqueiro na prática dos tribunais responsáveis pela guarda de suas respectivas constituições² ${ }^{2}$.

\footnotetext{
${ }^{1}$ Sobre o assunto vide: ACKERMAN, Bruce. The Rise of World Constitutionalism. In: Virginia Law Review, vol. 83, 1997, pp.. 771-797; CLÈVE, Clemerson Merlin. Direito Constitucional, Novos Paradigmas, Constituição Global e Processos de Integração. In: Revista Trimestral de Direito Civil, vol. 39, 2002, pp.. 23-32; DELMASMARTY, Mireille. Les forces imaginantes du droit: Le Relatif et Le Universel. Paris: Seuil, 2004; . Le forces imaginante du droit (II): Le pluralisme ordonné. Paris: Seuil, 2006; HÄBERLE, Peter. Estado Constitucional Cooperativo. Trad. de Marcos Augusto Malisca e Elisete Antoniuk. Rio de Janeiro: Renovar, 2007; PAGLIARINI, Alexandre Coutinho. Constituição Supranacional: uma internacionalização do Direito Constitucional. In: Revista Direitos Fundamentais e Democracia, vol 5/2009. Disponível em: $<$ <ttp://revistaeletronicardfd.unibrasil.com.br/index.php/rdfd/article/viewPDF>; $\quad$ NEVES, $\quad$ Marcelo. Transconstitucionalismo. São Paulo: Martins Fontes, 2009.

${ }^{2}$ No caso brasileiro vide, entre outros, os seguintes julgados: HC 79589 (direito de permanecer em silêncio 2000); HC 79812 (direito de permanecer em silêncio - 2000), HC 82424 (Caso Ellwanger - 2003); MC ADI 2551 (Vedação ao Confisco - 2003); HC 84203 (uso de prova ilícita - 2004); ADI 3105 (Tributação dos Inativos - 2004); RE 442683 (Possibilidade de efeito "ex nunc" no controle de constitucionalidade - 2005); RE 390840 (direitos do contribuinte - 2005); RE 346084 (direitos do contribuinte - 2005); MC MS 25647 (decoro parlamentar - 2005); MC MS 25579 (decoro parlamentar - 2005); HC 82788 (prova ilícita - 2005); RE 413782 (Poder de Intervenção do Estado e obrigações acessórias à obrigação tributária - 2005); ADI 2797 (Verticalização de Efeitos no Poder Judiciário - 2005); HC 87654 (crime contra a ordem econômica - 2006); HC 82959 (Individualização e Progressão da Pena - 2006); HC 90376 (prova ilícita - 2007); RE 370682 (crédito presumido - direito tributário - 2007); ADI 3112 (Estatuto das Armas - 2007); AgRRE 587604 (PIS/COFINS sociedade de advogados - isenção - 2008); RE 349703 (Prisão Depositário Infiel / Supralegalidade do Tratados 2008); MS 23441 (Princípio do Contraditório e Ampla Defesa - 2008); HC 94016 (Devido processo legal 2008); HC 93050 (utilização de prova ilícita - 2008) ADI 3999 (Direitos Políticos - Perda de cargo Eletivo decisão do TRE - 2008); ADI 3937 (Comercialização de Amianto - 2008); ED-RE 592.148 (Direito Tributário/Direito dos Contribuintes - 2009); Reclamação 6568 (Direito de Greve de Servidor Público - 2009); Petição 3388 (Petição Raposa Serra do Sol - 2009); HC 91676 (privação de liberdade/trânsito em julgado 2009); RE 466343 (Depositário Infiel - 2008); ADI 1194 (Vinculo Empregatício do Advogado - 2009); ADPF 130 (Lei de Imprensa - 2009); ADPF 153 (Lei de Anistia - 2010).
} 
Ocorre, todavia, que a utilização de precedentes estrangeiros não é realizada de maneira uniforme. Pelo contrário, é assistemática e, muitas vezes, carece de justificação e contextualização e, outras, parece ser desnecessária.

Importante esclarecer aqui o que se entende por direito ou precedente estrangeiro. São textos normativos ou decisões judiciais que não apresentam qualquer relação formal com ordenamento jurídico que as invoca para resolver determinado problema constitucional doméstico. Desta forma, partindo-se desta premissa, um acórdão da Suprema Corte Norte-Americana é tão "estrangeiro" ao ordenamento jurídico brasileiro quanto uma decisão da Corte Europeia de Direitos Humanos, embora de um ponto de vista doutrinário, elas possam ser classificadas, respectivamente, como corte nacional (estrangeira) e tribunal internacional.

Assim, o objeto deste trabalho é justamente analisar como estes elementos estrangeiros, em especial os precedentes, são e como deveriam ser manejados na resolução de problemas constitucionais pelo Supremo Tribunal Federal.

A justificativa deste estudo reside justamente no aumento ao recurso a elementos estrangeiros para decidir os litígios constitucionais denominados de "caso difíceis" e nas dificuldades teóricas que a globalização do direito constitucional, em especial o uso de precedentes estrangeiros, traz frente a uma tradição constitucional calcada na soberania do Estado e na sua história e cultura. Acresça-se a isso, a grande dificuldade em se lidar com temas abertos, como igualdade e liberdade, entre outros, e a importância de se tentar racionalizar a aplicação do direito.

É preciso mencionar ainda mais algumas delimitações sobre o tema ora estudado para permitir uma melhor compreensão do fenômeno e possibilitar, ao mesmo tempo, que este trabalho ofereça respostas adequadas ao assunto abordado.

Primeiramente, importante ressaltar que a pesquisa a ser realizada não tem como foco o estudo das teorias monista ou dualista do direito. Parte-se da premissa de que o Estado é ator indispensável para fazer atuar o direito e que, na atualidade, muitas cortes constitucionais e supremas cortes, como guardiãs das constituições nacionais e responsáveis por clarificar seus respectivos conteúdos, influenciam umas às outras, havendo uma interpenetração de sistemas jurídicos. 
Também é necessário frisar que foge do âmbito deste trabalho a questão sobre o status normativo dos tratados internacionais de direitos humanos dentro do ordenamento doméstico, bem como a discussão acerca da suposta hierarquia entre tribunais nacionais e supranacionais, uma vez que a dissertação a ser produzida busca avaliar os impactos da utilização de precedentes externos na produção de decisões constitucionais (especificamente no Brasil) e as formas de racionalizar seu uso, independentemente da relação vertical ou horizontal entre cortes. Como já dito, o que qualifica um precedente como estrangeiro não é a classificação do tribunal que o produz, mas, sim, a relação desta decisão com o ordenamento jurídico doméstico, isto é, a ausência de relação jurídica formal entre os ordenamentos, seja ela vertical ou horizontal, tem o condão de atribuir-lhe o status de "estrangeiro".

Em terceiro lugar, registre-se que este trabalho não se preocupará com aquelas questões referentes aos problemas mundiais ou regionais que, em virtude da globalização, dependem, para alcançar uma solução eficaz, da atuação coordenada de estados, como nos casos relativos ao meio-ambiente, ao terrorismo ou à lavagem de dinheiro. Aqui, soluções efetivas dependem de decisões coordenadas, o que não é, definitivamente, o caso deste estudo.

Em suma, discutir-se-ão os precedentes estrangeiros como fonte do direito constitucional no âmbito de controle de constitucionalidade, ou seja, em que medida e como elementos estrangeiros podem se tornar ferramenta útil na solução de questões constitucionais. Ou melhor, se existe, no ordenamento jurídico brasileiro, a possibilidade de invocar, como elemento argumentativo, precedentes estrangeiros no exercício da jurisdição constitucional.

Em função do objeto acima delimitado, o presente trabalho voltar-se-á, essencialmente, para a análise dos fundamentos sobre a utilização de precedentes estrangeiros, bem como para a busca de critérios que permitam um uso legítimo e racional dos elementos alienígenas.

Desta feita, num primeiro capítulo será abordada a noção de precedente estrangeiro para fins deste estudo, as diversas posições encontradas acerca da possibilidade de utilização de precedentes estrangeiros para solução de controvérsias 
constitucionais e, por fim, os fundamentos que permitem, no entender deste estudo, o uso de direito estrangeiro no controle de constitucionalidade.

Em seguida será elaborado um capítulo com um objetivo descritivo, no qual se buscará demonstrar a forma como os tribunais constitucionais têm utilizado os precedentes estrangeiros. O desiderato deste capítulo será justamente demonstrar que o uso de precedente estrangeiro pode ter várias finalidades e funções dentro de um julgado, bem como demonstrar que determinados modos de uso não têm como ser legitimados.

O terceiro capítulo, por sua vez, voltar-se-á para análise dos critérios sugeridos pela doutrina para a utilização de precedentes estrangeiros, bem como para a criação de um método ou, ao menos, balizas ou parâmetros que possam orientar a utilização de precedentes estrangeiros de modo a legitimar este uso.

Por fim, no quarto capítulo, realizar-se-á um estudo sobre o panorama jurídico brasileiro sobre este tema, analisando-se o comportamento do Supremo Tribunal Federal em relação aos precedentes estrangeiros em alguns casos paradigmáticos, para aferir se esta preciosa ferramenta de interpretação está sendo usada de forma adequada ou não.

Portanto, pode se afirmar que o presente trabalho partirá de uma perspectiva teórica, analisando os fundamentos e as premissas que permitem o uso de precedentes estrangeiros, passando, em seguida, por um estudo de caráter mais descritivo e classificatório que possibilitará a análise desta prática, e posteriormente, buscará, em função do material encontrado, propor formas de racionalizar e legitimar o uso de precedentes estrangeiros, fazendo, ao final, uma análise de casos brasileiros. 


\section{O DIREITO ESTRANGEIRO COMO FONTE DO DIREITO CONSTITUCIONAL: CORRENTES}

\subsection{APONTAMENTOS INICIAIS}

A ciência do direito vem, desde a metade do século passado, experimentando uma série mudanças que resultaram na quebra de vários de seus paradigmas. No contexto deste trabalho são relevantes aquelas relacionadas à perda de centralidade do papel do Estado (positivismo), à aproximação do direito com a moral e ética, ao crescimento do papel do Poder Judiciário ${ }^{3}$, aos novos problemas interpretativos e, por fim, ao surgimento de redes globais de comunicação e aproximação dos atores jurídicos ${ }^{4}$. Embora tais temas não sejam objeto do presente estudo, necessária uma breve digressão sobre eles para se aferir como tais mudanças impulsionaram a utilização de precedentes estrangeiros e internacionais.

Após os massacres das duas Grandes Guerras, houve um retorno, ainda que de forma não radical, à noção de direito natural e à ideia kantiana de que o individuo é sujeito de direito não em função de uma estatalidade, mas, sim, pelo fato de ser humano. A Declaração Universal dos Direitos Humanos (1948), elaborada logo após o fim da Segunda Guerra Mundial é o símbolo desta ideologia ${ }^{5}$. Esta declaração e as subsequentes aproximaram o direito da ética e da moral e adotaram linguagem flexível e indeterminada para alcançar o universalismo pretendido. Ademais, a experiência constitucional, em especial a ideia de controle de constitucionalidade, espalhou-se pelo globo (ainda que muitas vezes de

\footnotetext{
${ }^{3}$ Sobre o assunto: RAMOS, Elival da Silva. Ativismo Judicial: Parâmetros Dogmáticos. São Paulo: Saraiva, 2010.

${ }^{4}$ Sobre esta temática vide: SLAUGHTER, Anne-Marie. A Typology of Transjudicial Communication. In: 29 University of Richmond Law Review, Winter 1994, pp.. 99-137

${ }^{5}$ Segundo Celso Lafer, a principal inovação da Declaração Universal dos Direitos Humanos foi formular, "no plano universal, direitos humanos que não estão ao alcance de uma jurisdição nacional, pois leva em conta a tutela internacional de direitos que conferem, para falar com Hannah Arendt, o direito a ter direitos. Estes são os que a experiência totalitária mostrou que, ao serem negados pelo arbítrio discricionário da soberania, desempossam os seres humanos da condição de sujeitos de direitos, destituindo-os do benefício do princípio da legalidade, privando-os da valia e tornando-os supérfluos e, no limite, descartáveis". (Declaração Universal dos Direitos Humanos (1948). In: MAGNOLI, Demétrio. A história da paz. São Paulo: Contexto, 2008, p. 302)
} 
maneira deficiente) ${ }^{6}$ e reforçou a percepção de identidade de experiências (constitucionais) entre as nações.

A aludida aspiração ao universalismo inicialmente presente na esfera internacional (direitos humanos), paulatinamente, começou a se infiltrar no constitucionalismo estatal (direitos fundamentais), surgindo um movimento que buscava a convergência dos dois sistemas, na tentativa de retomar a ideia de que determinados direitos eram ínsitos à natureza humana.

É importante notar que mesmo para aqueles defensores do positivismo jurídico, o constitucionalismo moderno é permeado por algumas noções do direito natural (ou pela existência do direito natural), na medida em que se supõe, por exemplo, a existência do direito à resistência ao poder abusivo do Estado (poder tirânico) ${ }^{7}$.

Em decorrência destes movimentos de perda de centralidade do Estado (o ser humano como centro da ordem jurídica - dignidade da pessoa humana) e de expansão dos direitos fundamentais e humanos, passaram a compor o repertório da ciência do direito não apenas os estudos das normas, de suas fontes (de autoridade) e de suas relações, mas também a análise de valores sociais (moral/ética).

Neste quadro de expansão de direitos baseados em princípios, o Poder Judiciário passa a ser mais acionado, sendo obrigado a julgar os denominados "casosdifíceis", ou seja, aqueles em que o ordenamento jurídico não apresenta uma resposta pronta, mas que demandam a análise de conceitos abertos, com alto grau de abstração.

A dificuldade em lidar juridicamente com valores, ou seja, a inadequação da tradicional subsunção para tratar de valores plasmados nos princípios jurídicos juntamente com a noção de pré-compreensão desenvolvida por Hans-George Gadamer ${ }^{8}$, a qual

\footnotetext{
${ }^{6}$ A inegável deficiência aqui mencionada se refere ao papel transformador que a expressão constitucionalismo carrega, ou seja, o constitucionalismo se espalhou como promessa de liberdade e de igualdade para vários países com histórico de tirania e com grandes desigualdades sociais, havendo grande discrepância entre o constante no texto constitucional e a realidade de cada país. Sob esta perspectiva, a deficiência pode também ser vista não apenas como falência ou insuficiência do ideal constitucionalista, mas também como projeto a ser implementado onde os valores do constitucionalismo ainda não permeiam a cultura de uma sociedade.

${ }^{7}$ BOBBIO, Norberto. Direito e Poder. $1{ }^{\text {a }}$ ed. São Paulo: Editora UNESP, 2008, p. 206.

${ }^{8}$ SCHROTH, Ulrich. Hermenêutica Filosófica e Jurídica. In: KAUFMANN, Arthur; HASSEMER, Winfried (org.). Introdução à Filosofia do Direito e à Teoria do Direito Contemporâneas. Lisboa: Calouste Gulbenkian, 2002.
} 
pôs o intérprete no centro do processo de aplicação do Direito, demonstrou que as teorias interpretativas até então desenvolvidas eram insuficientes.

Em que pese a todas as dificuldades da hermenêutica em lidar com o elemento axiológico do direito, o fato é que o Poder Judiciário passou a ter papel mais central na criação do Direito, ao ter que analisar casos concretos em face de princípios abstratos e, para solucionar tais casos, conferir concretude a normas principiológicas.

Diante deste cenário, o denominado "direito judicial" passou a ter grande protagonismo dentro dos mais variados ordenamentos jurídicos. Segundo J. J. Canotilho "a investigação e obtenção do direito criadoramente feita pelos juízes ao construírem normas de decisão para a solução de casos concretos constitui um dos momentos mais significativos da pluralização das fontes do direito"". Vale dizer, os precedentes judiciais, dentro dos sistemas da "civil law", tornam-se a ser fontes do direito, uma vez que passaram a orientar a atuação dos operadores do direito ao estabelecer normas em casos difíceis.

Houve, desta feita, uma valorização e expansão da função jurisdicional no tocante ao seu papel de dizer o Direito. Ao se reconhecer ao Poder Judiciário a prerrogativa de manipular normas principiológicas, de conteúdo vago, a ciência jurídica voltou-se a procura de uma teoria ou de um método capaz de controlar ou prever o resultado desta manipulação. Neste diapasão surgiram as chamadas "teorias da argumentação"10 que se dedicam a estudar formas de dotar o ato interpretativo de racionalidade e previsibilidade.

Tais teorias fogem do escopo do presente trabalho, mas a menção a elas se faz necessária, pois, como se verá mais adiante, a invocação de precedentes estrangeiros se insere justamente na seara argumentativa e o trabalho busca levantar critérios para sua utilização racional.

Paralelamente ao desenvolvimento dessas teorias, a globalização permitiu a formação de redes de comunicação entre as cortes constitucionais, supremas

\footnotetext{
${ }^{9}$ CANOTILHO, J. J. Gomes. Direito constitucional e Teoria da Constituição. Coimbra: Almedina, 2000, p. 705.

10 ALEXY, Robert. Teoria da Argumentação Jurídica - A Teoria do Discurso Racional como Teoria da Fundamentação Jurídica. $3^{\text {a }}$ Ed. Rio de Janeiro: Forense, 2011..
} 
cortes $^{11}$ e tribunais internacionais, proporcionando intensa troca de experiências entre elas. $\mathrm{O}$ mesmo ocorreu com os operadores do direito, estudantes, juristas, magistrados e advogados, que, com o advento da internet, puderam ter contato com uma quantidade infindável de material alienígena, bem como interagir uns com os outros. Deve se assinalar, também, o fortalecimento dos direitos humanos na seara internacional e o surgimento de inúmeras ONGs defensoras dos direitos humanos no globo, que buscam uma aplicação universal destas normas.

Neste ambiente mais permissivo quanto à interpretação constitucional e de grande fluxo de informações e de comunicação entre os atores jurídicos, o uso de material estrangeiro na tomada de decisões constitucionais passou a ser mais frequente. Em outras palavras, o diálogo entre Cortes Constitucionais e Tribunais Internacionais teve aumento significativo em virtude da globalização e do desenvolvimento do constitucionalismo, sendo que a citação ou recurso a precedentes de outras cortes constitucionais e tribunais internacionais passou a ser algo comum ${ }^{12}$.

Vários autores têm se debruçado sobre o fenômeno para justificar e implementar a possível convergência ou, ao menos, a interlocução constitucional.

Para Luis Cláudio Coni ${ }^{13}$, o direito internacional deve prevalecer sobre a Constituição e deve-se reformular a dogmática da interpretação constitucional, para que se reconheça uma ordem constitucional global. Pugna o autor por uma "hermenêutica constitucional aberta ou extrovertida, porque esta, em última análise, permitirá a preservação dos valores constitucionais internacionais, conforme expressos na Constituição da

\footnotetext{
${ }^{11}$ Conforme notícia Luís Cláudio Coni, em seu artigo intitulado "Diplomacia Judicial" (disponível em http://www2.stf.jus.br/portalStfInternacional/cms/destaquesNewsletter.php?sigla=newsletterPortalInternacionalF oco\&idConteudo $=217832$ ), as Supremas Cortes, inclusive a brasileira, possuem uma assessoria internacional, incumbida de levar a cabo o contato e a troca de ideias entre os tribunais nacionais.

${ }^{12}$ Há vários trabalhos estrangeiros que fizeram levantamentos estatísticos que comprovam esta assertiva. Vide: GELTER, Martin and SIEMS, Mathias M.. Networks, Dialogue or One-Way Traffic? An Empirical Analysis of Cross-Citations between Ten of Europe's Highest Courts. March 22, 2011. In: Maastricht European Private Law Institute (M-EPLI) Working Paper n. 2011/03. Disponível em: ; ___ and __. Language, Legal Origins, and Culture before the Courts: Cross-Citations between Supreme Courts in Europe. November 21, 2010. In: Supreme Court Economic Review, vol. 21, 2013. Disponível em: http://ssrn.com/abstract=1719183; MARKESINIS, Basil. National Selfsufficiency or Intellectual Arrogance? The current attitude of American Courts towards foreign law. In: The Cambridge Law Journal, 65, 2006.

${ }^{13}$ CONI, Luis Cláudio. A internacionalização do Poder Constituinte. Porto Alegre: Sergio Antonio Fabris Editor, 2006, p. 41.
} 
República". Desta feita, permitir-se-ia a construção de uma ordem de valores compartilhada em uma convergência horizontal.

Com opinião menos radical, Mireille Delmas-Marty ${ }^{14}$ e Marcelo Neves ${ }^{15}$ vislumbram mais interlocução do que hierarquia na convergência ou diálogo. Ademais de enxergarem um diálogo entre Cortes Nacionais e Cortes Supranacionais, também salientam a importância do diálogo entre Cortes Constitucionais. Ambos os estudiosos entendem que o Estado (e sua jurisdição constitucional), apesar de não mais ser o único ente produtor de normatividade, ainda é o locus privilegiado e indispensável para a realização do Direito $^{16}$.

Enquanto a autora francesa fala em "porosidade ou permeabilidade do direito"17, o autor brasileiro recorre ao termo "pontes de transição"18. Desta forma, pode se dizer que a permeabilidade do direito permite o estabelecimento de pontes de transição entre as jurisdições constitucionais. Contudo, a ausência de hierarquia mencionada por esses teóricos do Direito não implica em ausência de conflito, mas apenas em influência recíproca.

Peter Häberle, por sua vez, fala em uma liga de interpretação da constituição ${ }^{19}$ e da internacionalização da sociedade aberta de intérpretes da constituição. J.J. Canotilho, por seu turno, apoiado no jurista germânico, aponta para a importância da interpretação comparativa e toma a ideia de Häberle ao chamá-la de "quinto método de interpretação", no qual ele vê uma "comparação jurídica valorativa no âmbito do Estado Constitucional" que permite uma comunicação entre constituições para se solucionar problemas comuns ${ }^{20}$. No entanto, os estudos mencionados apenas descrevem de maneira

\footnotetext{
${ }^{14}$ DELMAS-MARTY, Mireille. Le Forces imaginante du droit (II): Le pluralisme ordonné. Paris: Seuil, 2006.

${ }^{15}$ NEVES, Marcelo. Transconstitucionalismo. São Paulo: Martins Fontes, 2009.

${ }^{16}$ No entanto, não se pode deixar de mencionar que para Mireille Delmas-Marty (Le Forces imaginante du droit (II)..., p. 53) esta noção de direito sem hierarquia é apenas uma fase transitória na construção de uma verdadeira ordem mundial.

${ }^{17}$ Les forces imaginantes du droit..., p. 40.

${ }^{18}$ Transconstitucionalismo, p. 117.

${ }^{19}$ HÄBERLE, Peter. Estado Constitucional Cooperativo. Trad. de Marcos Augusto Malisca e Elisete Antoniuk. Rio de Janeiro: Renovar, 2007, p. 55.

${ }^{20}$ Direito constitucional e Teoria da Constituição. Coimbra: Almedina, 2000, p. 1224.
} 
ampla o fenômeno da globalização do direito, mas não se debruçam sobre os fundamentos para esta interlocução, nem tem por intuito estabelecer critérios para o uso de precedentes estrangeiros ou, analisar de maneira criteriosa a forma em que ocorre esta interlocução entre as cortes constitucionais.

De qualquer forma, é inegável que o direito estrangeiro e o direito internacional estão sendo utilizados nos processos de tomada de decisões constitucionais e passaram a fazer parte, de maneira mais intensa e explícita, do catálogo de elementos a serem manuseados pelos juízes constitucionais para interpretação da constituição. É o que Virgílio Afonso da Silva denomina de "integração jurídica discursiva", baseada em um diálogo constitucional que ocorre no nível da argumentação e que permite a "aproximação do discurso jurídico" ${ }^{\text {21 }}$. É por esta perspectiva que se pode ver o direito estrangeiro como fonte do Direito.

Importante frisar que a ideia de uma "ferramenta discursiva" que permite a interlocução entre os mais diversos tribunais nacionais e internacionais é bastante precisa e melhor delimita o fenômeno em discussão. Embora a maioria dos trabalhos científicos utilize a expressão "uso de precedentes estrangeiros", eles não se resumem apenas ao uso de precedentes estrangeiros, possuindo escopo mais amplo, ao englobar a utilização do direito estrangeiro (legislação, precedentes e doutrina) como elemento auxiliar na tomada de decisões estrangeiras.

Além disso, ressaltar o aspecto discursivo minimiza a forte carga de autoridade que advêm do conceito de precedente oriundo do sistema da "common law". Nos ordenamentos jurídicos influenciados por este sistema, a noção de precedente está intimamente ligada ao conceito de autoridade, ou seja, à força vinculante das decisões das cortes superiores, as quais devem ser seguidas pelas cortes inferiores pertencentes à mesma jurisdição independentemente de seu conteúdo ou de suas razões ${ }^{22}$. Em contraste, as decisões

\footnotetext{
${ }^{21}$ SILVA, Virgílio Afonso da. Integração e diálogo constitucional na América do Sul. In: PIOVESAN, Flavia; VON BOGDANDY, Armin; ANTONIAZZI, Mariela Morales. (Org.). Direitos humanos, democracia e integração jurídica na América do Sul. Rio de Janeiro: Lumen Juris, 2010, v. 1, pp.. 515-530.

${ }^{22}$ Reconhece-se que nem sempre as decisões judiciais no sistema da "common law" têm força vinculante e que o magistrado, neste sistema, tem a sua disposição uma série de mecanismos para não adotar determinado precedentes. Contudo, ainda sim, se comparado ao sistema da "civi law", o direito da "common law" dota os precedentes judiciais de grande força e autoridade, sendo estas umas das características que o difere do direito de origem romano-germânica.
} 
oriundas de outras jurisdições são denominadas, na "common law", de fonte persuasiva, isto é, aquela que é seguida por sua substância, ou melhor, por suas razões e argumentos. Em suma, elas não têm força de precedente (autoridade), mas, sim, força persuasiva, de convencimento. É justamente neste último sentido que se fala no recurso ao uso de precedente estrangeiro, em que pese à impropriedade do termo.

No entanto, embora a invocação de direito estrangeiro como elemento importante na tomada de decisões constitucionais venha ocorrendo com certa constância, inclusive no Supremo Tribunal Federal ${ }^{23}$, o tema ainda não chamou muita atenção acadêmica no Brasil, em que pese à sua relevância. A produção doutrinária sobre o assunto é incipiente. $\mathrm{Na}$ verdade, poucos autores nacionais se debruçaram sobre o tema ${ }^{24}$.

O mesmo ocorre no continente europeu, onde o uso de precedentes estrangeiros é bastante disseminado. Contudo, aparentemente, não há maiores preocupações acerca de uma teorização ou criação de uma metodologia para o mencionado uso.

Também as Cortes Supremas do Canadá ${ }^{25}$ e da África do $\operatorname{Sul}^{26}$ fazem um uso constante de precedentes estrangeiros, que ocorre de uma maneira mais

\footnotetext{
${ }^{23}$ A utilização de precedentes estrangeiros pelo Supremo Tribunal Federal será melhor detalhada no capítulo 5 deste trabalho. Por ora, basta a constatação de que o tribunal brasileiro vem recorrendo com certa frequência ao direito internacional e precedentes estrangeiros e que este fenômeno tem apresentado um crescimento progressivo.

${ }^{24}$ Até o momento foram encontrados apenas seis trabalhos sobre o assunto. André Ramos Tavares escreveu artigo intitulado "Modelos de uso da jurisprudência constitucional estrangeira pela justiça constitucional" (In: Biblioteca Digital Revista Brasileira de Estudos Constitucionais, Belo Horizonte, n. 12, ano 3, Outubro 2009), Marcelo Figueiredo publicou texto denominado "Notas a respeito da utilização de jurisprudência estrangeira pelo Supremo Tribunal Federal no Brasil” (ibidem), Gustavo Vitorino Cardoso dedicou-se ao tema elaborando o artigo "Direito Comparado na Jurisdição Constitucional" (In: Revista Direito GV São Paulo, 6(2), Jul/Dez 2010, pp.. 469-492), Guilherme Amorim Campos da Silva defendeu tese de doutorado perante a Pontifícia Universidade Católica de São Paulo (PUC/SP), intitulada "O uso de precedente estrangeiro pela Justiça Constitucional - Uma Teoria de Unificação do Direito Constitucional Material”, Virgílio Afonso da Silva publicou o artigo "Integração e diálogo constitucional na América do Sul” (op. cit., pp.. 515-530) e, por fim, Luiz Magno Pinto Bastos Junior elaborou o artigo "Utilización del derecho constitucional comparado en la interpretación constitucional: nuevos retos a la teoría constitucional". (In: Revista Peruana de Derecho Publico, v. 8, 2007, pp.. 79-108).

${ }^{25}$ Vide: Regina v. Keegstra (1990 - 3 S.C.R. 697) e Regina v. Van der Peet (1996, 2 S.C.R. 507).

${ }^{26}$ Vide: State v. Zuma (Case No. CCT/5/94), Du Plessis v. De Klerk (Case No. CCT 8/95), State. v Makwanyane (Case No. CCT/3/94 ), entre outros.
} 
elaborada, mas que, no entanto, ainda não foi sistematizado adequadamente como uma teoria ou metodologia.

Diferentemente dos cenários brasileiro e europeu, o ambiente acadêmico norte-americano encontra-se mergulhado em um intenso debate ${ }^{27}$ sobre o tema desde o julgamento, pela Suprema Corte Norte-Americana, do caso Roper v. Simmons ${ }^{28}$.

Na realidade, a polêmica se iniciou um pouco antes, em 2002, quando, ao julgar o caso Atkins v. Virginia $^{29}$, a Suprema Corte Americana entendeu que a $8^{\mathrm{a}}$ Emenda Constitucional vedava a aplicação de pena de morte aos deficientes mentais que viessem a ser condenados por algum crime punido com a pena capital. Nesta oportunidade, ao elaborar o voto vencedor, Justice Stevens, em nota de rodapé ( $\left.\mathrm{n}^{\circ} 21\right)$, asseverou: "Ademais, dentro da comunidade mundial, a imposição de pena de morte aos delitos cometidos por criminosos com retardamento mental é fortemente reprovada". Os dois Justices vencidos, Scalia e Rehnquist, em seus votos, criticaram o argumento de Stevens, sendo que Scalia aduziu: "igualmente irrelevantes são as práticas da comunidade mundial, cujas noções de justiça (graças a Deus) nem sempre são as do nosso povo. Nunca devemos nos esquecer que é a Constituição dos Estados Unidos da América que nós estamos interpretando".

A discussão voltou à tona no julgamento do caso Lawrence $v$. $\operatorname{Texas}^{30}$. Devia a Suprema Corte decidir se a Lei contra Sodomia do Estado do Texas ofendia o direito fundamental do indivíduo à liberdade e à privacidade. A maioria, por meio de voto elaborado pelo Justice Kennedy, entendeu que a lei texana ofendia a Constituição americana. Nesta mesma ocasião, restou consignado que a Corte superava o precedente vinculante Bowers v. Hardwick ${ }^{31}$, o qual era no sentido de manutenção da Lei Antissodomia. Entre

27 Importante deixar registrado que muitos autores norte-americanos defendem que a citação de direito estrangeiro pela Suprema Corte Americana é um recurso utilizado desde seu surgimento. Nesse sentido: FONTANA, David. Refined Comparativism in Constitutional Law. In: UCLA Law Review, vol. 49, 2001, p. 539; . The Rise and Fall of Comparative Constitutional Law in the Postwar Era. In: Yale Journal of International Law, vol. 36, 2011, p. 1; CALABRESI, Steven and ZIMDAHL Stephanie Dotson. The Supreme Court and Foreign Sources of Law: Two Hundred Years of Practice and The Juvenile Death Penalty Decision. In: 47 William \& Mary Law Review, 2005, p. 743. Todavia, o que importa para os fins deste estudo é que a polêmica se iniciou de forma contundente no início da década passada.

${ }^{28} 543$ U.S. 551 - 2005

${ }^{29} 536$ U.S. 304 - 2002

${ }^{30} 539$ U.S. 558 - 2003

${ }^{31} 478$ U.S. 186 - 1986 
inúmeros fundamentos invocados, ressaltou-se a posição da Corte Europeia de Direitos Humanos que, em caso similar, condenou a Irlanda do Norte, por sua legislação violar as normas da Convenção Europeia de Direitos Humanos. Abrindo divergência e criticando fortemente a utilização de material estrangeiro, Justice Scalia afirmou que o direito estrangeiro é insignificante para a Suprema Corte Americana, salientando que o voto vencedor ignorava também decisões estrangeiras contrárias ao entendimento nele plasmado.

Por fim, em Roper v. Simmons, julgamento em que se analisava a aplicabilidade da pena de morte a menores de idade à época da prática do delito, a Suprema Corte, por maioria apertada, posicionou-se pela inconstitucionalidade da norma, vedando a pena capital em casos envolvendo menores. Justice Kennedy, ao elaborar o voto relativo ao entendimento majoritário, levou em conta a opinião da comunidade mundial sobre o tema, que, de modo geral, repudia a sujeição de menores à pena de morte ${ }^{32}$. Mais uma vez, Justice Scalia elaborou um longo voto, no qual critica a utilização de precedentes estrangeiros de maneira geral, bem como condena seu uso de acordo com as conveniências das circunstâncias $^{33}$.

Como já mencionado, as aludidas decisões provocaram um intenso debate sobre a utilização de direito estrangeiro por parte da Suprema Corte dos Estados Unidos da América. O debate gerou tamanha controvérsia que, conforme noticia Toni M. Fine ${ }^{34}$, foi apresentado nas duas Casas do Congresso Americano um projeto de lei

\footnotetext{
32 "É apropriado que tomemos conhecimento da esmagadora opinião internacional contra a pena de morte aplicada a menores, baseada, em grande parte, no entendimento de que a instabilidade e desequilíbrio emocional dos jovens pode muitas vezes ser um fator no cometimento do crime. A opinião da comunidade mundial pode não controlar o resultado de nosso julgamento, mas dota-o de respeito e serve de significante confirmação de nossas próprias conclusões".

33 "Pior ainda, o Tribunal diz explicitamente que as leis de nosso povo sobre o assunto não importam: 'Ao final, nosso próprio julgamento terá que se manifestar sobre a aceitabilidade da pena de morte com base na $8^{\mathrm{a}}$ Emenda. (aspas omitidas). O Tribunal, portanto, se proclama o único árbitro de nossa nação em padrões morais e - no curso de desenvolver esta enorme responsabilidade - pretende inspirar-se nas opiniões dos tribunais e das legislaturas estrangeiros. Porque eu não acredito que o significado de nossa $8^{\mathrm{a}}$ Emenda, mais do que o significado de outras disposições de nossa Constituição, deva ser determinada pelos pontos de vista subjetivos de cinco membros deste Tribunal, com opinião consentânea com as dos estrangeiros, por isso, eu divirjo. (...) As autoridades estrangeiras, em outras palavras, nem sequer falam sobre a questão, aqui, diante de nós'. (...) A Corte deve ou reconsiderar todos estes temas sobre a perspectiva dos estrangeiros ou deve parar de considerar as opiniões estrangeiras. Invocar direito alienígena quando se concorda com o fundamento de alguém e ignorar quando se discorda não é uma decisão racional e fundamentada, mas, sim, um sofisma".
}

${ }^{34}$ FINE, Toni M. O judiciário americano e o direito internacional: o novo debate. In: Biblioteca Digital Revista Brasileira de Estudos Constitucionais, Belo Horizonte, n. 12, ano 3, Outubro 2009, pp.. 4-5. 
denominado de "Lei de Restauração Constitucional", o qual visava proibir as Cortes Americanas de fazer qualquer remissão a direito estrangeiro ou internacional. Na mesma época, parlamentares americanos cogitaram sobre o impeachment de juízes federais que adotassem precedentes estrangeiros para fundamentar suas decisões.

No campo acadêmico, as aludidas decisões da Suprema Corte Norte-Americana também geraram muita polêmica e estimularam a elaboração de inúmeros trabalhos sobre o assunto tanto a favor como contra o uso de precedentes estrangeiros.

No entanto, não há, ainda, uma teoria ou ao menos um consenso de como se deve proceder ao se usar o material alienígena no enfrentamento de questões constitucionais.

De acordo com Roger P. Alford ${ }^{35}$, muito provavelmente, a ausência de uma teoria ou de um método decorre das perspectivas dos estudiosos que lidam com o assunto. Por um lado, o tema é mais estudado pelos internacionalistas, que se preocupam mais com a concepção de um direito transnacional, que dê maior aplicação e efetividade às normas e aos precedentes internacionais, do que com a sistematização de um método para racionalizar o diálogo entre as Cortes. Por outro lado, os constitucionalistas, até o momento, pouco se ocuparam do tema, pois, apesar da globalização e da abertura normativa das constituições atuais, a centralidade estatal ainda pauta em muito o estudo do constitucionalismo.

Sujit Choudhry ${ }^{36}$, por sua vez, entende que a ausência de uma teoria é justamente o combustível para este polêmico debate. Para ele, a doutrina constitucional não acompanhou a rápida expansão do uso de direito estrangeiro pelas Cortes Constitucionais. Com efeito, até o momento, o uso de direito estrangeiro pelo Poder Judiciário tem sido estudado de maneira descritiva e preocupando-se apenas com a legitimação do uso, deixando-se de lado a conceituação de temas importantes e as consequências normativas subjacentes a esta nova prática constitucional. Em suma, a academia ainda não prestou a devida atenção ao assunto, o qual ainda carece de uma sistematização.

\footnotetext{
${ }^{35}$ ALFORD, Roger P. In search of a Theory for Constitutional Comparativism, In: UCLA Law Review, vol. 52, n. 3, February 2005, pp.. 642-644.

${ }^{36}$ CHOUDHRY, Sujit. Globalization in Search of Justification: Toward a Theory of Comparative Constitutional Interpretation. In: Indiana Law Journal, vol. 74, n. 3, 1999, pp.. 819-892.
} 
No Brasil, André Ramos Tavares ${ }^{37}$ é um dos poucos a chamar a atenção para o problema, asseverando que "a jurisprudência estrangeira tem sido invocada, em muitos países, sem maiores preocupações metodológicas ou de legitimidade quanto ao seu uso; na maior parte dos casos, sequer a pertinência e o grau de vinculação são objeto de esclarecimentos."

Ante a ausência de um método de uso de precedentes estrangeiros, alguns autores, principalmente norte-americanos, passaram a se dedicar ao estudo deste fenômeno, buscando justificativas e limites para o mesmo, havendo ainda, aqueles que se opuseram radicalmente à interlocução constitucional. Três principais posições podem ser elencadas: os universalistas, os isolacionistas e os moderados.

Como será demonstrado a seguir, a primeira corrente, pelos seus fundamentos, não requer a elaboração de uma metodologia consistente. A segunda posição, por refutar o uso de direito estrangeiro, não busca desenvolver qualquer teoria para utilização de direito estrangeiro. Por fim, a terceira corrente, ao fundamentar a utilização de precedentes dentro de uma racionalidade jurídica é justamente aquela que deve apresentar uma sistemática capaz de nortear a manipulação de material alienígena.

Mas, antes de se analisar cada uma das referidas correntes, imprescindível delimitar e esclarecer precisamente o fenômeno que é objeto deste trabalho, qual seja ou uso de precedentes e direito estrangeiro no enfrentamento de questões constitucionais. Para isso, será necessária uma breve passagem pelos estudos do direito comparado para salientar a diferença entre o uso de direito estrangeiro na tomada de decisões constitucionais e a utilização para fins de transplante ou transferência legal.

\footnotetext{
37 TAVARES, André Ramos. Modelos de uso da jurisprudência constitucional estrangeira pela justiça constitucional. In: Biblioteca Digital Revista Brasileira de Estudos Constitucionais. Belo Horizonte: n. 12, ano 3, Outubro 2009. Disponível em: <http://www.bidforum.com.br/bid/PDI0006.aspx?pdiCntd=65598>, p. 1.
} 
1.2 A VISÃO DO DIREITO COMPARADO E O OBJETO DESTE TRABALHO: OS TERMOS TRANSPLANTES LEGAIS E EMPRÉSTIMOS CONSTITUCIONAIS VERSUS O CONCEITO DE MIGRAÇÃO DE IDEIAS CONSTITUCIONAIS

Não há como negar, em um primeiro momento, que a questão sobre a utilização de precedentes e direito estrangeiros pelas cortes constitucionais poderia se aproveitar das discussões travadas no âmbito do direito comparado que, de longa data, se dedica ao estudo acerca da possibilidade de transplantes legais por meio de reformas legislativas e sua consequente efetividade. Desta forma, tantos os argumentos a favor, como contra os transplantes legais poderiam ser transpostos para a discussão acerca do uso de precedentes estrangeiros na jurisdição constitucional.

Ocorre, todavia, que o assunto é extremamente polêmico e, na realidade, não reflete, de maneira adequada, o fenômeno jurídico objeto deste trabalho. Desta feita, o presente tópico tem por finalidade afastar a discussão comparatista e, ao mesmo tempo, delimitar de maneira precisa o objeto estudado neste trabalho. Por fim, ainda busca definir o melhor termo para descrever o fenômeno ora analisado.

A discussão na seara comparatista, como já dito, é acerca da possibilidade ou não da realização de transplantes ou transferências legais entre ordenamentos jurídicos nacionais, isto é, se é possível destacar uma norma, um conjunto de normas, ou uma instituição de uma nação e inseri-las em outra, mantendo-se o objeto transferido praticamente inalterado.

O mais famoso defensor da possibilidade de transplantes legais é o professor inglês Alan Watson ${ }^{38}$ cuja tese defende, em síntese, que: a) a história do direito na civilização ocidental comprova que os transplantes efetivamente acontecem; b) o transplante consubstancia-se na transferência de regras legais entre sistemas jurídicos; c) tais transplantes são a principal forma de disseminação das ideias jurídicas; e d) a constatação das transferências legais indica a inexistência de uma ligação íntima entre direito e sociedade.

Em conclusão, para Watson, a lei e o direito não mudam em virtude de pressões ou elementos externos a ela, pois isto significa reduzir o direito à

\footnotetext{
${ }^{38}$ WATSON, Alan. Legal Transplants and European Private Law. In: 4.4 Eletronic Journal of Comparative Law, Dec. 2000, http://www.ejcl.org/ejcl/44/44-2.html, passim.
} 
sociologia, à economia ou à política ${ }^{39}$. Pela perspectiva de Watson, os transplantes são feitos de forma fácil, sem maiores dificuldades ${ }^{40}$.

Opondo-se a estas ideias, tem-se a teoria do professor francês Pierre Legrand ${ }^{41}$, cujos fundamentos podem ser assim sintetizados: a) o direito não pode ser reduzido a regras positivas; b) direito e cultura são intimamente ligados; c) o significado de uma norma é apenas extraído dentro de um contexto e não apenas de seu aspecto semântico; d) a interpretação jurídica é um produto cultural; e) os transplantes legais são impossíveis, uma vez que a norma ou o instituto transplantado perde seu significado na cultura receptora.

Em suma, esse autor rejeita a possibilidade de transplantes legais, haja vista que eles somente seriam possíveis se ambos, o contexto e a regra legal, fossem passíveis de transferência.

Esta posição radical, na qual o direito perde quase toda sua autonomia, é chamada de "contextualismo", "culturalismo" ou "teoria do direito como espelho" (da sociedade/comunidade).

Importante notar que as críticas de Legrand ${ }^{42}$ decorrem de uma outra discussão, também travada na seara do direito comparado, sobre a metodologia e a finalidade deste campo do direito. Ele se insurge quanto à finalidade funcionalista ${ }^{43}$ atribuída

\footnotetext{
${ }^{39}$ Em defesa de Alan Watson vide o artigo: EWALD, William B. Comparative Jurisprudence (II): The Logic of Legal Transplants. In: American Journal of Comparative Law, vol. 43, 1995, pp.. 489-510.

${ }^{40}$ Watson reconhece a influência de fatores externos sobre os transplantes legais. No entanto, ele os considera de pouca importância no processo de transplante.

${ }^{41}$ LEGRAND, Pierre. The impossibilty of Legal Transplants. In: 4 Maastricht J. Eur. \& Comp. L., 1997, p. 111.

${ }^{42}$ The same and the different. In:____ _ MUNDAY, Roderick (orgs). Comparative Legal Studies: Traditions and Transitions. Cambridge University Press, 2003, pp.. 240-311. Cambridge Books Online. Disponível em: http://dx.doi.org/10.1017/CBO9780511522260.

${ }^{43}$ De acordo com Ruti Teitel (Comparative Constitutional Law in a Global Age. In: 117 Harvard Law Review, 2004, pp.. 2570-2596) a teoria funcionalista do direito comparado surgiu no início do século passado e via o direito comparado como uma técnica de solução de problemas. A matéria do direito comparado é o problema legal, apartado de seu contexto. Em suma, o intento da comparação é a funcionalidade. Vale frisar que o funcionalismo foi e é muito usado no direito privado, mas agora os doutrinadores passaram a usá-lo no direito constitucional, principalmente na interpretação constitucional. Ocorre, todavia, que uma das características da teoria funcionalista no campo privado foi a busca de seu desenvolvimento apartado das questões políticas. A partir do final do século passado houve um ressurgimento do funcionalismo no tocante ao constitucionalismo. Para a autora norte-americana, porém, o problema derradeiro no coração do neofuncionalismo é a relação entre seus meios e fins. Afinal, este projeto comparativista tem a aspiração de definir um constitucionalismo normativo que seja universal, uma ciência universal. Ainda para esta autora o foco no universalismo ou problemas comuns significa se esquivar dos problemas da realidade política e partir de uma suposta neutralidade cultural para o
} 
ao direito comparado por alguns doutrinadores, isto é, ele refuta a premissa de que todos os sistemas jurídicos solucionam seus problemas de maneira similar e que o estudioso do direito comparado deveria focar sua investigação nas semelhanças, desconsiderando as diferenças, pois estas seriam apenas aparentes. A grande crítica refere-se à ambição de universalidade que levaria à convergência dos sistemas jurídicos ${ }^{44}$.

É patente que as duas teorias têm por objeto a transferibilidade de normas e institutos jurídicos e se opõem radicalmente em virtude das premissas assumidas: sob uma perspectiva os transplantes legais são não só possíveis, como também são a principal forma de disseminação de ideias jurídicas; por outra, qualquer forma de transferência legal seria impossível, pois a norma ou instituto transferido perderiam seu significado no processo de transferência.

É justamente por se voltarem para a possibilidade ou não de transplantes legais e serem tão extremistas que as teorias desenvolvidas no campo do direito comparado não servem ao estudo do fenômeno objeto deste trabalho. A polarização leva, sem dúvidas, a uma simplificação indevida do tema.

Primeiramente, cumpre salientar que o fenômeno aqui denominado de uso de direito estrangeiro por tribunais constitucionais não se confunde com a noção de transplantes legais. Como será demonstrado adiante, as cortes, ao manusearam elementos do direito estrangeiro no processo de controle de constitucionalidade, não o fazem com o intuito de procederem à realização de um transplante legal, mas o utilizam (ou deveriam utilizá-lo) com intuito de buscar melhores argumentos (racionalidade), aferir eventual consenso mundial, analisar a consequência de determinada decisão ou, ainda, refletir acerca do próprio ordenamento. Em face de tantas possibilidades para o uso de direito estrangeiro, resta

constitucionalismo. Abstraindo-se o constitucionalismo de seu conceito cultural, possibilita-se a construção de um constitucionalismo ideal. Contudo, este esforço parece paradoxal: se o objetivo do projeto funcionalista depende da busca de um constitucionalismo ideal construído fortemente sobre um amplo processo de abstração, será praticamente impossível avaliar a qualidade do constitucionalismo fora de contexto político e social.

${ }^{44}$ Vlad Perju, em interessante artigo intitulado "Provocations" (Forthcoming, 125 Harvard Law Review Forum, June 2012; Boston College Law School Legal Studies Research Paper n. 270. Disponível em:

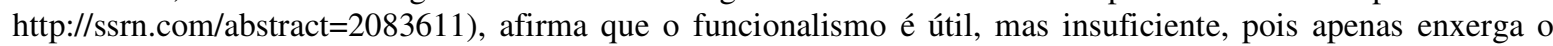
direito como mero solucionador de problemas, cuja eficiência e sucesso é de difícil aferição, desconsiderando o papel da cultura, da política e da história. De acordo com ele, é preciso transcender o funcionalismo, em enxergar um horizonte mais amplo para o direito constitucional comparado. 
claro que ele não reflete a ideia de transferência legal e que, ademais, vai muito além deste conceito fechado.

Em segundo lugar, as teses comparatistas, por serem radicais, não conseguem capturar as nuances do fenômeno jurídico ora estudado. Com efeito, não se pode negar a influência da cultura sobre o direito. Todavia, também não se pode negar o fluxo de ideias constitucionais, pois elas, inegavelmente, acontecem, principalmente após o processo de expansão do constitucionalismo. Ademais, na proporção em que o presente trabalho for se desenvolvendo restará claro que a ligação entre direito e cultura pode ou não vir a ser importante no manejo material estrangeiro pela Corte Constitucional, a depender do assunto a ser tratado, isto é, a ligação entre direito e cultura pode variar, desde íntima conexão até a separação total, o que, de certa forma afasta a discussão comparatista.

Por fim, afastar-se da discussão comparatista significa apartar-se da querela funcionalista, focada simplesmente na ideia de solução de problemas comuns, reafirmando-se que o fenômeno em tela é melhor visto como uma técnica interpretativa e uma prática discursiva. O foco se desloca da discussão sobre a finalidade do direito comparado para a seara da interpretação constitucional e sua racionalidade ${ }^{45}$.

Feitas estas considerações, pode se dizer que a discussão travada no âmbito do direito comparado é insuficiente para o estudo do fenômeno em tela, haja vista a estreiteza do conceito de transplante legal, que não abarca todas as possibilidades que podem advir do chamado diálogo constitucional. Por outro lado, mesmo que fosse possível se utilizar das lições do direito comparado quanto aos transplantes legais, as duas correntes não colaborariam em muito, uma vez que o direito não pode ser totalmente desconectado da cultura (e de outros sistemas), mas, ao mesmo tempo, não há como ignorar a conversa constitucional entre as cortes, o diálogo jurídico transnacional ${ }^{46}$.

\footnotetext{
${ }^{45}$ Neste sentido: TEITEL, Ruti. Comparative Constitutional Law in a Global Age...

${ }^{46}$ Otto Kahn-Freunde, ao abordar o tema dos transplantes legais efetuados por meio da legislação (reformas legais), propõe uma divisão entre aquilo que é passível de transferência e aquilo que não é em decorrência de fortes ligações com a cultura e com a estrutura política, isto é, ele reconhece que determinadas instituições não seriam necessariamente reflexo da cultura e da sociedade. Assim, ao se desligar da obsessão entre autonomia do direito e culturalismo, ele foca na distinção entre o que é transferível e aquilo que não e nas interações entre o que é transplantado e o ambiente receptor (KAHN-FREUND, Otto. On Uses and Misuses of Comparative Law. In: The Modern Law Review, 37(1), 1974, pp.. 1-27. No mesmo sentido aponta o jussociólogo Gunther Teubner, que refuta a posição de Legrand e defende Watson, reconhecendo, no entanto, a incompletude da tese do professor
} 
Outros autores do campo do direito constitucional comparado, em vez de se utilizarem do termo transplantes legais, optaram por denominar o fenômeno em tela de "empréstimos constitucionais",47, provavelmente muito influenciados pelos empréstimos feitos para a elaboração de novas constituições para países recémdemocratizados.

O termo empréstimo remete o leitor à ideia de tomar um livro emprestado em uma biblioteca ou dinheiro em um banco. Ele traz consigo a noção de que o objeto emprestado deverá ser devolvido e que permaneça sendo o mesmo, sem qualquer alteração. Além disso, esta metáfora também implica no reconhecimento de que haveria um estoque de conhecimento constitucional que apenas poderia ser emprestado com a autorização do emprestador e que o tomador não buscaria o empréstimo para recusá-lo logo em seguida.

Diferentemente, conforme demonstram Sujit Choudhry ${ }^{48}$ e Kim Lane Scheppele ${ }^{49}$, o termo "empréstimos constitucionais" também é inadequado para descrever o intercâmbio de precedentes entre as Cortes Constitucionais.

De fato, o uso de direito estrangeiro por uma Corte Constitucional é algo mais espontâneo, que não requer a autorização da Corte provedora para o Tribunal receptor, uma vez que a utilização de precedentes estrangeiros independe de autorização. Da mesma forma, o bem ou produto constitucional "emprestado" não precisa ser

inglês. Com efeito, Teubner rejeita o que ele denomina de falsa dicotomia, consistente no binômio rejeiçãorepulsa que pauta o assunto acerca dos transplantes legais e assevera que embora Watson tenha comprovado a ocorrência de vários transplantes de sucesso no Ocidente, ele subestima a relação entre direito e sociedade. Em suma, Teubner entende que os modelos alienígenas provocam "irritações legais", ou seja, provocam uma série de reações que afetam tanto o objeto importado como o ambiente importador, alterando o discurso jurídico como um todo (TEUBNER, Gunther. Legal Irritants: Good Faith in British Law or How Unifying Law Ends up in New Divergences. In: The Modern Law Review vol. 61, n. 1, Jan. 1998, pp.. 11-32).

${ }^{47}$ Neste sentido: BÖHMER, Martin. Borrowings and Acquisitions: The Use of Foreign Law as a Strategy to build Constitutional and Democratic Authority. In: Seminario en Latinoamérica de Teoría Constitucional y Política, Panel 3, Hybrid Legal Cultures: Borrowings and Impositions Papers (14/06/2007), San Juan, Porto Rico, Yale Law School, 2007; ADLER, Matthew D. Can Constitutional Borrowing be Justified? A Comment on Tushnet. In: University of Pennsylvania Journal of Constitutional Law, 1998, pp.. 350-357; EPSTEIN, Lee and KNIGHT, Jack. Constitutional Borrowing and nonborrowing. Published in 2003. In I-CON: International Journal of Constitutional Law 1, pp.. 196-223.

${ }^{48}$ CHOUDHRY, Sujit. Migration as a New Metaphor in Comparative Constitutional Law. In: The Migration of Constitutional Ideas. Cambridge University Press, 2006.

${ }^{49}$ SCHEPPELE, Kim Lane. The Migration of Anti-Constitutional Ideas: The Post-9/11 Globalization of Public Law and the International State of Emergency. In CHOUDHRY, Sujit (ed.). The Migration of Constitucional Ideas... 
devolvido ou, ainda, restar inalterado. Por fim, o uso de direito estrangeiro poderá resultar em recusa ou refuta à efetiva utilização de uma ideia constitucional externa, isto é, um uso negativo, o que não seria possível no caso de se usar a metáfora dos empréstimos.

Assim, os dois autores acima mencionados cunharam o termo "migração de ideias constitucionais", o qual, como uma metáfora, melhor descreve o fenômeno do uso de precedente estrangeiros na jurisdição constitucional, uma vez que a noção migração é mais ampla e voluntária, pois pode o migrante transitar sem a autorização de seu Estado $^{50}$, dele não depende e para ele não precisa retornar. Além disso, o migrante não precisa manter sua cultura, podendo se adaptar ao novo ambiente. Enfim, nas palavras Scheppele ${ }^{51}$, a ideia de:

(...) migração abre todo um campo metafórico que contempla grandes transformações, diferentes tipos de relações de poder em diferentes pontos do processo de migração e uma maior rede de conexões entre o migrante e o contexto. Migração é uma ideia que permite a consideração de uma grande flexibilidade, amplo conjunto de relações, conexões mais complicadas entre pontos de origem e de destino que ocorrem no mundo das ideias legais. Migração como metáfora abre nossas mentes para o direito constitucional comparado.

Choudhy ${ }^{52}$ acrescenta, ainda, que o termo migração tem o mérito de afastar a ideia de universalismo e convergência, oriundas do funcionalismo, pois, para ele, a ideia de diferença é um conceito chave e ao mesmo tempo relativo, o qual justamente permite a comparação entre sistemas jurídicos distintos, possibilitando-se, desta forma, a percepção daquilo que é similar e daquilo que é singular. Neste diapasão, o exercício da comparação não necessariamente leva à convergência dos sistemas legais, podendo muitas vezes acentuar as diferenças constitucionais.

\footnotetext{
50 Scheppelle, em seu texto, fala em migrações forçadas, referindo-se às imposições externas de ideias constitucionais. No entanto, para fins do presente trabalho esta hipótese não será considerada, pois, aqui, está-se a tratar da utilização de precedentes estrangeiros no controle de constitucionalidade e não da influência do constitucionalismo estrangeiro sobre o poder constituinte originário.

${ }^{51}$ Ibidem, p. 349.

${ }^{52}$ Migration as a new methaphor in comparative constitutional law..., p. 22.
} 
Em suma, a expressão migração de ideais constitucionais é a que melhor descreve o objeto do presente trabalho, uma vez que ao mesmo tempo em que reconhece a possibilidade de trânsito de ideias constitucionais entre as ordens jurídicas também considera a possibilidade de diferença, da necessidade de adaptação ou até mesmo de recusa da ideia migrante, sem que isso signifique convergência.

Em outras palavras, ela amplia o escopo do estudo à medida que aumenta as possibilidades de interação entre os tribunais constitucionais, levando a Corte receptora a analisar o material estrangeiro, tanto dentro de seu contexto de origem, como dentro da nova jurisdição, não com o fito de realizar um mero transplante legal, mas, sim, com objetivo de refletir acerca das razões e motivos que culminaram naquela ideia constitucional, estando livre para, se necessário, adotá-la ou adaptá-la para contexto doméstico ou, ainda, para recusá-la, sempre tendo como finalidade um autoconhecimento do próprio sistema e a adoção da melhor solução para o ordenamento jurídico interno.

Ademais, como bem salienta Vlad Perju ${ }^{53}$, a mudança de empréstimos para migração permite que o fenômeno do uso de precedentes estrangeiros não seja estudado somente com base na adoção de precedentes, isto é, quando há uma utilização positiva de material estrangeiro, mas também volta-se para o estudo das causas que levam os sistemas jurídicos a recusar a interação, sendo que estudo mais amplo resulta numa análise das estruturas normativas fundantes de cada ordenamento constitucional.

Além das expressões acima mencionadas, outras mais foram criadas: difusão ou circulação de ideias constitucionais, fertilização cruzada, engajamento constitucional, transmissão constitucional, recepção constitucional, etc. No presente estudo se adotará o termo migração constitucional da maneira como exposta neste tópico.

Postas estas premissas, o trabalho retorna para o estudo das diversas posições acerca da migração de ideias constitucionais.

\footnotetext{
${ }^{53}$ PERJU, Vlad. Constitutional Transplants, Borrowing, and Migrations. In: Boston College Law School Faculty Papers. Paper 360, 2012, p. 09.
} 


\subsection{OS UNIVERSALISTAS}

A corrente universalista parte da premissa que todas as Cortes Constitucionais e Tribunais Internacionais devem estar empenhados na identificação de um mesmo conjunto de princípios. Como explica Sujit Choudhry ${ }^{54}$, eles vislumbram unidade no meio da diversidade e tendem a não levar em consideração as diferenças legais e culturais.

A atividade interpretativa é levada ao extremo e a criação do Direito é justificada pela procura de princípios e valores que transcendem os limites do Estado e são afetos a todos os seres humanos. A ênfase é em valores comuns, em contraponto ao funcionalismo do direito comparado que focava o estudo na solução de problemas comuns ${ }^{55}$. Há uma incessante busca por convergência e, neste caso, a utilização de decisões de outras cortes é instrumento capaz de revelar os direitos imanentes e transcendentes.

Em suma, a universalidade da experiência humana justifica os empréstimos transnacionais e as abstrações metafísicas.

Como expoente desta doutrina no cenário brasileiro, Antonio Cançado Trindade fala em "Civitas Maxima Gentium" e recorre à ideia de "universalidade do gênero humano". Declara abertamente sua filiação ao direito natural, o qual deriva da razão humana e impõe limites a conduta irrestrita dos governantes dos Estados. Defende a existência de uma "consciência jurídica universal ("Opinio Juris Communis"), que possui normas imperativas ("Jus Cogens"). Funde o Direito com a Ética. Para ele, cabe ao jurista dizer qual é o Direito, recorrendo à consciência humana ${ }^{56}$.

Nos Estados Unidos da América, Anne-Marie Slaughter ${ }^{57}$, por sua vez, fala em uma comunicação transjudicial e defende a existência de uma comunidade global de cortes empenhada em realizar uma "missão conjunta substantiva", com o fito de proteger os direitos humanos. Embora reconheça a diferença entre o diálogo vertical, em que

\footnotetext{
${ }^{54}$ Globalization in Search of Justification..., p. 833.

55 Neste sentido: MCCRUDDEN, Christopher. Judicial Comparativism and Human Rights. In: Oxford Legal Studies Research Paper Series, n. 29/2007, pp.. 371-398.

${ }^{56}$ Corte IDH, Opinión Consultiva OC-18/03 de 17 de septiembre de 2003, solicitada por los Estados Unidos Mexicanos, sobre la condición jurídica y derechos de los migrantes indocumentados.

${ }^{57}$ SLAUGHTER, Anne-Marie. A Typology of Transjudicial Communication. In: 29 University of Richmond Law Review, Winter 1994, pp.. 99-137.
} 
cortes estão ligadas formalmente de maneira hierárquica, e o diálogo horizontal, entre Cortes sem conexão formal, a autora norte-americana entende tratar-se de um mesmo fenômeno jurídico que visa à proteção dos direitos humanos. Para ela, há um "processo coletivo" de deliberação judicial sobre uma série de problemas comuns ou, ainda, um "processo universal de deliberação judicial". Estes processos coletivos têm como premissa uma concepção de identidade judicial que enfatiza a autonomia judicial, uma forma de autocompreensão por meio da qual as cortes engajadas na conversa transjudicial se autoreconhecem e reconhecem suas semelhantes estrangeiras como cortes independentes de suas instituições governamentais, que coexistem com a comunidade de Estados. Por fim, ainda, crê na criação de uma Constituição Global e num Estado de Direito Global ${ }^{58}$.

Em outros termos: o Direito é visto como princípio, princípios ético-filosóficos, os quais transcendem fronteiras. A transcendência justifica, por si só, o uso comparativo da jurisprudência. A comprovação empírica de um direito transcendental é sua presença em vários ordenamentos. Como esclarece Sujit Choudhry ${ }^{59}$, "a presença de um princípio legal em muitos ordenamentos jurídicos é uma evidência de sua correção ou retidão. Convergência empírica, em outras palavras, é prova de moral verdadeira".

Pode se afirmar que a posição perfilhada pelos universalistas, que busca encontrar um direito universal aplicável a todos em qualquer lugar, torna esta corrente naquela que dá ao juiz maior liberdade de manipulação dos precedentes estrangeiros, pois, ao partir de uma premissa universal, podem ser desconsideradas questões ligadas a similaridades entre os ordenamentos envolvidos (aquele que recebe o precedente e aquele de onde provém o julgado), a compatibilidade dos sistemas, as características sociais e culturais de cada Estado, elemento que, se levados em conta, poderiam afastar a utilização do material alienígena. Neste diapasão, percebe-se que os defensores desta posição são mais guiados por uma ideologia, do que propriamente preocupados com um método ou técnica capaz de manejar o uso racional do material estrangeiro.

\footnotetext{
${ }^{58}$ Interessante mencionar que Slaughter em seu artigo, contraditoriamente, defende a ideia de valores universais, empreitada comum, comunidade de cortes com uma mesma missão, etc., para ao final aduzir que não defende o universalismo. No entanto, não explica sua posição e também não explica como este diálogo deve ocorrer.

${ }^{59}$ Globalization in Search of Justification..., p. 890.
} 
A tônica desta corrente é uma busca incessante por convergência, baseada em premissas normativas superiores que agiriam como limite a qualquer legislação ou atividade estatal que ofendesse as normas universais dos direitos humanos. Tais premissas são anteriores ao Estado e inalienáveis. Logo, devem ser observadas.

Muitas são as objeções levantadas contra esta corrente.

Logo de início um obstáculo se põe: a dificuldade de se elaborar argumentos universalistas ou transcendentes face à diversidade normativa dos ordenamentos jurídicos. Em outras palavras, muitas vezes, é praticamente impossível encontrar uma unidade normativa que permitisse a descoberta de normas verdadeiras, válidas perante todos.

Ademais, a diversidade normativa é apenas reflexo da diversidade cultural e social existente no globo terrestre. Embora possam haver normas universais ou quase universais, há grande variação de entendimento sobre elas e o Direito é reflexo destas variações. Buscar uma verdade universal desconsidera o Direito como fenômeno cultural e social.

Em segundo lugar, essa corrente, ao dotar o juiz de grande liberdade interpretativa, pode vir a acentuar, inadvertidamente, a discricionariedade judicial, deslocando-se de maneira indevida o centro da produção de Direito do Poder Legislativo para o Poder Judiciário, uma vez que ela avoca para si o poder de revelar as ditas normas universais e não presta deferência à legislação.

Em terceiro lugar, a postura universalista de nada serve em assuntos polêmicos ou controversos. Como supor que se encontrará uma norma transcendente em assuntos que, devido aos aspectos culturais ou sociais, provocam reações opostas nas mais diversas sociedades? Como encontrar uma moral verdadeira sobre determinados assuntos? Quais seriam os precedentes estrangeiros que revelam uma verdade superior? Resta evidente a dificuldade de se manusear o material estrangeiro quando se parte do fundamento que a presença de determinada norma nos mais diversos ordenamentos é sinal de verdade, especialmente quando há decisões em diversos sentidos.

Por fim, a adoção da corrente universalista, por estar mais preocupada em criar um direito universal, em buscar a efetividade de normas universais, pouco ou em nada ajuda o esforço de dotar a ciência jurídica de cientificidade. 


\subsection{OS ISOLACIONISTAS}

É a corrente que refuta qualquer possibilidade de interação entre Cortes Constitucionais ou entre estas e Tribunais Internacionais, ou seja, o Juiz jamais deve, ao decidir, recorrer a material estrangeiro. Nega tanto a possibilidade de usar de ideias alienígenas na solução de controvérsias constitucionais, bem como qualquer forma de influência externa. De certa forma, pode ser denominado de protecionismo constitucional.

Em sua grande maioria, os isolacionistas encontram-se nos Estados Unidos da América e invocam em sua defesa seis argumentos: (1) o excepcionalismo americano (superioridade e singularidade da experiência americana), (2) o originalismo (a Constituição deve ser interpretada de acordo com a vontade de seus criadores, os Fundadores da Pátria), (3) a democracia (aspecto majoritário), (4) e (5) a suposta incapacidade dos juízes americanos em lidar com o material estrangeiro.

$\mathrm{Na}$ realidade, os argumentos acima mencionados podem ser resumidos em três eixos principais. Primeiro, o originalismo, que tem em como assunção implícita o excepcionalismo da experiência política norte-americana. Em segundo lugar, a questão democrática e ofensa à soberania, que correspondem ao direito de autodeterminação no âmbito interno e externo, respectivamente. Por fim, a dificuldade dos magistrados constitucionais manusearem o material estrangeiro.

Importante ressaltar, antes de analisar cada uma das críticas isolacionistas, que a celeuma sobre o uso de precedentes estrangeiros é, nos Estados Unidos, muito acalorada, ultrapassando os limites acadêmicos. Vários são os argumentos que destoam de qualquer discussão que busque ser produtiva e pautada pela racionalidade. Conforme noticia Austen L. Parrish ${ }^{60}$, um professor de direito chegou a dizer que a citação de fontes estrangeiras seria uma evidência de inferioridade intelectual. Em artigo em que refuta a possibilidade de se usar direito estrangeiro, Ernest A. Young ${ }^{61}$ afirma que os magistrados e doutrinadores defendem o diálogo das cortes constitucionais, pois trata-se de tema da moda

\footnotetext{
${ }^{60}$ PARRISH, Austen L. Storm in a Teacup: The U.S. Supreme Court's Use of Foreign Law. In: University of Illinois Law Review, vol. 2, 2007, pp.. 638-639.

${ }^{61}$ YOUNG, Ernest A. The Trouble With Global Constitutionalism. In: 38 Texas International Law Journal, 2003, pp.. 527-545.
} 
que lhes proporciona convites para participar de conferencia e viagens. Ken I. Kersch ${ }^{62}$, por seu turno, assevera que o uso de direito estrangeiro e a defesa da existência de uma comunidade global de cortes é reflexo de esforços calculados por ativistas de esquerda que falharam ao tentar se impor politicamente e, agora, buscam impor uma visão moralizadora e administrativa por meio do Poder Judiciário, sugerindo que a Suprema Corte Americana estivesse sendo manipulada. Tais assertivas demonstram o grau de hostilidade e polarização que o tema alcançou nos Estados Unidos, o que demonstra que os argumentos isolacionistas devem ser analisados com cautela para se filtrar a forte questão ideológica que permeia a $\operatorname{disputa}^{63}$.

$\mathrm{O}$ argumento originalista é de longe, o mais invocado e ele decorre, inegavelmente, da noção de que os Estados Unidos da América refletem a experiência única e excepcional de um povo, no caso, o povo norte-americano. Segundo o originalismo, a interpretação da Constituição deve sempre ser feita com olhos voltados para o que os "Founding Fathers" tinham em mente quando elaboraram o documento constitucional americano, sendo que a não observação desta premissa resulta sempre em ativismo judicial injustificado e inaceitável.

Em outras palavras, os componentes da Suprema Corte NorteAmericana devem, ao analisar a sua constituição, se aterem apenas às deliberações que culminaram na elaboração do texto constitucional e que revelam o entendimento do povo americano na época da promulgação da constituição. Note-se que o originalismo se funda em duas premissas: a de que a constituição decorre da vontade dos fundadores da pátria (vontade do povo) e de que esta vontade é imutável no decorrer do tempo, exceto pelo processo de emenda previsto no próprio texto constitucional.

$\mathrm{O}$ argumento referente à ofensa ao princípio democrático, por sua vez, também é bastante comum. Argumenta-se, com muita ênfase, que o direito

\footnotetext{
${ }^{62}$ KERSCH, Ken I. The New Legal Transnationalism, the Globalized Judiciary, and the Rule of Law, In: Washington University Global Studies Law Review 4, 2005, pp.. 345-387.

${ }^{63}$ No artigo "The Judge as Comparatist", Basil Markesinis e Jörg Fedtke apontam que a discussão americana pode ser de pouco valor, por estar vinculada e subordinada à constituição americana e às teorias americanas do textualismo e do originalismo. Para aqueles não familiarizados com estes temas, a discussão poderia parecer estranha ou sem importância (MARKESINIS, Basil and FEDTKE, Jörg. The Judge as Comparatist. In: 80 Tulane Law Review, November 2005, p. 11).
} 
estrangeiro e o supranacional deve ser rechaçado por não resultarem, dentro dos Estados Unidos, de um consenso democrático ${ }^{64}$. Ao juiz não é dado o poder para modificar o direito doméstico, pois isto significaria o mesmo que dizer que outros povos teriam o poder de interferir em questões domésticas norte-americanas ${ }^{65}$. A utilização de precedentes estrangeiros ofenderia a soberania norte-americana, pois uma vontade externa à vontade do povo americano teria o condão de afetar a autodeterminação do povo dos Estados Unidos. Como já dito, duas são as objeções: o precedente estrangeiro estaria, por um lado, contrariar as decisões políticas do povo americano e, por outro, impor a vontade de um Estado estrangeiro.

Outro argumento de peso articulado pelos isolacionistas se dirige à utilização desorganizada dos precedentes estrangeiros, em virtude da suposta falta de capacidade das cortes em lidar com direito alienígena. A mencionada incapacidade decorreria tanto de dificuldades oriundas da quantidade infindável de material estrangeiro, como do despreparo dos juízes constitucionais para lidarem com ordenamentos jurídicos que não o seu. Para os isolacionistas, estes dois fatores não permitem que um verdadeiro trabalho comparativo seja realizado ${ }^{66}$.

Relacionadas às objeções do parágrafo anterior, os isolacionistas ainda aduzem que o uso do direito estrangeiro acarretaria um ônus argumentativo desnecessário para o juiz, em razão da já referida dificuldade de compreendê-lo e justificá-lo. Esta circunstância deixaria a jurisdição constitucional refém de experts chamados a explicar o precedente estrangeiro.

Por fim, ainda argumentam que todas estas circunstâncias em conjunta gerariam, ante a falta de uma sistemática racional para o uso de precedentes estrangeiros, o risco de utilizações seletivas e oportunistas ${ }^{67}$.

\footnotetext{
${ }^{64}$ Neste sentido: MCGINNIS, John O. Contemporary foreign and international law in constitutional construction. In: Albany Law Review, vol. 69, 2006, p. 806.

${ }^{65}$ Para Mcginnis, a utilização de precedentes estrangeiros "dá a povos de outras nações a capacidade de formatar nossa política (americana)" (Idem, p. 807).

${ }^{66}$ ALFORD, Roger P. Misusing International Sources to Interpret the Constitution. In: American Journal of International Law, vol. 98, n. 57, 2004, p. 64.

${ }^{67}$ Neste sentido: SUNSTEIN, Cass R. A Constitution of many minds: Why the Founding Document's Doesn't Mean What It Meant Before. New Jersey: Princeton, 2009 e ANNUS, Taavi. Comparative Constitutional Reasoning: The Law and Strategy of Selecting the Right Arguments. In: 14 Duke Journal of Comparative \& International Law, 2004, pp.. 301-350.
} 
Embora pareçam, em um primeiro momento, bem fundamentadas, a objeções isolacionistas não resistem a uma análise mais detida.

Inicialmente, no tocante ao argumento originalista ${ }^{68}$, três observações são capazes de afastá-lo. Primeiramente, há de se considerar a dificuldade de se aferir a intenção original dos Pais da Pátria, o que, de plano, demonstra que mesmo o originalismo, em sua suposta pureza, está sujeito ao "cherry picking" de fatos históricos e supostas intenções, pois nada impede o intérprete de escolher os fatos que lhe convenham ${ }^{69}$. Além disso, muito procedente a crítica de Mark Tushnet $^{70}$, a qual questiona a premissa originalista que atribui ao poder constituinte a capacidade de criar um documento fortemente integrado, ideia esta reflexa do mito do legislador racional. Com acerto, o jurista americano aponta para tensão entre compromisso com a racionalidade e a aleatoriedade no processo de elaboração constitucional e sugere que seria equivocado presumir que os constituintes se pautaram por um processo altamente racional da maneira proposta pelos originalistas. A crítica não deixa de reconhecer que há integração e racionalidade no processo de feitura constitucional, mas é pertinente à medida que assevera que elas não são tão amplas e não se estendem a toda constituição.

Em segundo lugar, como frisa Vicki C. Jackson ${ }^{71}$,

A Constituição é nossa porque muitas gerações a fizeram da maneira como ela é, por meio de um complexo processo que começa com a adoção do texto original e emendas, mas que foi construído com

\footnotetext{
${ }^{68} \mathrm{O}$ presente trabalho, muito embora se volte para a problemática da teoria originalista, não se aprofundará no seu debate, uma vez que tal teoria é fortemente ligada ao direito norte-americano e tem raízes profundas no método de interpretação deste país, enquanto que, no Brasil, este método não é detidamente discutido ou posto como objeção. Para um entendimento mais profundo acerca do tema vide: MORALES, Cesar Mecchi. Originalismo e interpretação constitucional. Tese de Doutorado, FD/USP, 2011.

${ }^{69}$ Conforme explica Parrish (Storm in a Teacup..., pp.. 664-665): "Em terceiro lugar, (a ideia de) que o originalismo vai limitar os juízes mais do que os outros métodos interpretativos é improvável, e, ao menos, controvertida. Para muitos, 'o entendimento original é não mais que um artífice para impor sua própria (do juiz) visão política', e continua: 'uma crítica que também cabe ao originalismo refere-se a situações em que a história e o texto são ambíguos. Metodologicamente, a doutrina é um retrocesso: como as questões postas sob análise tornam-se mais difíceis, a necessidade de estar aberto para outras fontes aumenta. As disposições constitucionais não apresentam um único significado em qualquer comunidade antes do processo de interpretação”.

${ }^{70}$ TUSHNET, Mark. The Possibilities of Comparative Constitutional Law. In: 108 Yale Law Journal, 1999, p. 1225 .

71 JACKSON, Vicki C. Constitutional Comparisons: Convergence, Resistance, Engagement. In: Harvard Law Review, vol. 119, n. 1, Nov 2005, p. 121.
} 
camadas de contestação e interpretação - incluindo interações anteriores com ideias e práticas compartilhadas por comunidades transnacionais - que moldaram seu significado no decorrer do tempo. A Constituição não visava proteger a igualdade entre homens e mulheres e as minorias raciais somente porque elas foram "dadas" em 1789, ou 1868, ou 1920, mas por causa do contínuo embate sobre seu significado.

Isto é, a Constituição é uma construção no tempo, não possuindo significado estanque, sendo necessária sua constante atualização.

Ademais, há de se ter em mente que não se pode tomar a constituição americana como parâmetro. A uma porque as constituições elaboradas no pósguerra são inegavelmente influenciadas, na sua feitura, pelo direito estrangeiro e internacional. A duas, pois muitas constituições modernas, como a brasileira e a indiana, embora reflitam a história de seus povos, na realidade são mais projetos para o país do que meramente uma carta que estrutura o poder e limita a ação do Estado. Em outras palavras, são constituições que visam alterar a realidade social do país e não manter o status quo. Assim, em terras que não as americanas, o originalismo perde muito de sua força.

No que se refere à crítica relacionada ao ativismo judicial, esta não procede, pois é próprio da interpretação constitucional a consideração de fontes interpretativas diversas, como o texto, as intenções dos Constituintes, a história, os valores da sociedade e os resultados práticos da decisão. Na realidade, o ativismo decorre mais da estrutura principiológica da constituição, do próprio controle de constitucionalidade e das dificuldades interpretativas advindas destas estruturas normativas, do que da invocação do uso de direito estrangeiro. Na realidade, o ativismo judicial é um problema que pode englobar a utilização de precedentes estrangeiros, mas não está diretamente a ela relacionada.

Sobre o assunto, interessante observação faz Austen L. Parrish ${ }^{72}$ sobre os isolacionistas no sentido de que a maior parte das críticas sempre recaem sobre o peso dado à autoridade estrangeira, mas em momento algum, dirige-se contra o uso de fonte estrangeira em si. Ressalta que,

\footnotetext{
${ }^{72}$ Storm in a Teacup..., pp.. 655-656.
} 
A interpretação constitucional já concede aos juízes ampla liberdade, requerendo uma seleção de argumentos, entre eles, texto, intenção, precedente, a história, consequências, valor, estrutura e pragmatismo. É comum os juízes citarem outras autoridades/fontes secundárias, tais como tratados acadêmicos, enciclopédias jurídicas, viradas de jurisprudência, relatórios das comissões legislativas, artigos jurídicos, dicionários jurídicos e até mesmo, ocasionalmente, livros e artigos que estão completamente 'fora da lei'. O Tribunal é conhecido por enriquecer seus votos com a citação de fontes que vão desde ' $M$ * $A$ * $\mathrm{S} * \mathrm{H}$ *' e Vila Sésamo, de manuais como 'the Manly Culture of York Barbell' a à música popular e poesia, e às obras de Platão, Aristóteles, Shakespeare, Montesquieu, entre outros. Mesmo fontes extralegais, como as posições de grupos privados ou de indivíduos, são, por vezes citadas para fundamentar uma decisão. Os juízes podem usar este material de qualquer forma que desejarem. E como materiais estranhos, essa autoridade é muitas vezes usada apenas persuasivamente para fundamentar um voto que a Corte havia concluído de forma independente.

Completa seu raciocínio afirmando que atualmente o Direito tornou-se fortemente interdisciplinar, obrigando o Juiz a recorrer às mais diversas fontes.

Percebe-se, desde logo, que o uso seletivo de fontes de argumentação não é, como querem fazer crer os isolacionistas, um problema ínsito ao uso de precedentes estrangeiros, mas, sim, um problema oriundo do caráter interpretativo da ciência jurídica, presente em boa parte das decisões judiciais, em especial, nas decisões dos casos difíceis.

Tal raciocínio também se aplica à crítica que entende que o uso de precedente estrangeiro aumenta desnecessariamente o ônus argumentativo do juiz. No âmbito doméstico, o juiz também tem à sua disposição uma grande variedade de fontes que podem ser selecionadas e estudadas, o que não lhe impede de utilizá-las. Além disso, muitas vezes, o recurso ao direito estrangeiro pode, mesmo que traga um ônus argumentativo maior, trazer vantagens ao permitir a produção de uma decisão melhor. Obviamente que o uso de precedentes estrangeiros de maneira volumosa pode vir, sim, a prejudicar a argumentação e 
sua compreensão, mas não se está aqui a defender uma compilação de todas as decisões estrangeiras sobre um determinado assunto.

No que concerne à defesa da soberania como elemento capaz de vetar a utilização de precedentes estrangeiros, a crítica não merece acolhida. Tal argumento confunde o uso de direito estrangeiro como uma ajuda interpretativa, presumindo que a fonte estrangeira está prevalecendo ou controlando o direito interno. Na realidade, o juiz ao analisar a jurisprudência estrangeira apenas está procurando possibilidades e fundamentos para decidir o caso sob seus cuidados, não havendo qualquer evidência de que a fonte estrangeira tenha se tornado fonte de autoridade ${ }^{73}$.

Na verdade, conforme leciona André Ramos Tavares, a noção de soberania não deve ser vista como uma proibição absoluta ao uso de precedentes estrangeiros, mas sim como vedação à adoção de um modelo de submissão ${ }^{74}$, isto é, “um uso reverencial de decisões externas"

No que se refere ao aspecto democrático, os isolacionistas afirmam que a utilização de decisões oriundas de cortes estrangeiras pode ofender as escolhas

\footnotetext{
${ }^{73}$ Conforme leciona Giuseppe de Vergottini: "O direito estrangeiro não se aplica no próprio ordenamento por parte do juiz. Não constitui fonte normativa que se acrescenta às fontes válidas para o juiz. É mais uma variedade cognitiva que se soma à generalidade dos elementos fáticos que devem ser considerados (ambientais, sociais, históricos e, portanto, também jurídicos de natureza normativa, jurisprudencial e doutrinária de procedência externa). $\mathrm{O}$ argumento para a invocação de normativas constitucionais e legislativas também vale para as referências a precedentes jurisprudenciais" (...) "O Juiz em sua argumentação não aplica, portanto, direito ou precedentes estrangeiros, apenas os utiliza como elementos fáticos úteis para a finalidade de interpretar melhor e de maneira mais proveitosa o próprio direito" (DE VERGOTINI, Giuseppe. Más allá del diálogo entre tribunales - Comparación y relación entre jurisdicciones. $1^{\text {a }}$ Ed. Pamplona, Espanha: Thompson Reuters, 2010, p. 242 e 291)

${ }^{74}$ Interessante a observação sobre o tema feita por Christopher A. Whytock, no artigo intitulado "Foreign Law in Domestic Courts: Different Uses, Different Implications". Para este autor, em razão de os diferentes usos do direito estrangeiro pelas cortes domésticas serem associados a diferentes graus e qualidades de internalização da norma e porque a internalização da norma depende de saliência doméstica, as críticas ao uso do direito estrangeiro baseada em preocupações sobre imposição da "vontade judicial" perdem sentido (p. 56), pois não haveria submissão, haja vista que a comunidade não aceitaria passivamente qualquer imposição. Ademais, ainda segundo o autor, mesmo que as cortes domésticas tenham por objetivo internalizar o direito estrangeiro, este esforço provavelmente terá pouco impacto, ao menos que o direito estrangeiro tenha legitimidade suficiente entre as normas domésticas existentes. Na realidade, para se aferir o verdadeiro resultado do uso de direito estrangeiro se depende da complexa cadeia de causalidade em cada caso, isto, é, além da importação de material, há o papel da corte e a recepção de sua decisão no país importador (WHYTOCK, Christopher A. Foreign Law in Domestic Courts: Different Uses, Different Implications. In: JACKSON, Donald W.; TOLLEY, Michael C.; VOLCANSEK, Mary L. Globalizing Justice: Critical Perspectives on Transnational Law and Cross-Border Migration of Legal Norms. Albany: State University of New York Press, 2010, Chapter 3, pp.. 45-63).
}

${ }^{75}$ Modelos de uso da jurisprudência..., p. 7. 
legitimamente tomadas pelo povo de determinado Estado. Certamente se uma corte Constitucional meramente transpusesse um precedente estrangeiro para decidir um caso doméstico, sem fazer qualquer análise do ordenamento interno, haveria ofensa à democracia. Contudo não é sobre isto que se esta aqui a falar. Os precedentes estrangeiros, na esmagadora maioria das vezes, são apenas um entre vários elementos utilizados por uma corte para tomar uma decisão, não havendo que se falar em submeter um povo à vontade de outro ${ }^{76}$.

Como será demonstrado adiante, o uso de precedentes estrangeiros não deve ser realizado desconsiderando-se a constituição doméstica ou ignorando a vontade popular. Seu manuseio adequado se dá na seara argumentativa, compondo um de vários elementos da fundamentação de dada decisão.

Neste diapasão, há de se ter de se ressaltar que embora a função de controle de constitucionalidade tenha também caráter político, a legitimação das decisões judiciais nesta seara não ocorre unicamente por meios democráticos, mas há de ser alcançada por meio do um processo aberto pautado pela racionalidade. Em síntese, o controle de constitucionalidade, não retira sua legitimidade apenas por meio de deliberações majoritárias, mas também por meio de decisões públicas, abertas e construídas racionalmente, diferenciando-se, neste ponto, das decisões meramente políticas. É justamente neste processo racional que o precedente estrangeiro pode ser utilizado legitimamente.

Assim, no tocante ao direito comparado, as cortes que recorrerem ao uso de direito estrangeiro devem esclarecer porque o fizeram, explicando tanto os fundamentos que permitem o uso destas matérias como a forma em que foram utilizados. Se assim não proceder, o tribunal não estará produzindo uma decisão judicial em sede de controle de constitucionalidade, mas mera decisão política transvestida de linguagem jurídica, sem transparência e qualquer controle democrático ${ }^{77}$.

\footnotetext{
${ }^{76}$ Basil Markesinis e Jörg Fedtke explicam claramente "que o argumento da imposição da vontade estrangeira por meio da decisão judicial é completamente equivocado, pois assume que a visão do juiz estrangeiro está sendo imposta de uma forma antidemocrática. Na realidade o que ocorre é que a ideia estrangeira, quando convenceu o juiz doméstico de seu mérito, torna-se parte do direito interno porque ele, o juiz - democraticamente nomeado escolheu acolher a posição estrangeira por seu próprio raciocínio. Para aqueles que acreditam na troca de ideias, nada poderia ser mais atrativo e, se há algum perigo nesta prática, ele está no fato de que o juiz "importador" poderia compreender erroneamente (provavelmente inconscientemente) o direito estrangeiro, mas não de maneira supostamente antidemocrática". (op. cit., p. 57 e 135).

${ }^{77}$ Neste sentido vide: CHOUDHRY, Migration as a new methaphor..., p. 4.
} 
Sob esta perspectiva, a crítica isolacionista merece acolhimento, pois as decisões judiciais devem se pautar pela transparência e pela fundamentação detalhada de cada argumento. $\mathrm{O}$ uso que não observa estes mandamentos pode, por via indireta, acarretar ofensa à democracia ao não observar o procedimento de legitimação das decisões judiciais.

No que tange à crítica referente à dificuldade ou à falta de capacidade para a compreensão do material estrangeiro, esta também não merece guarida. Primeiramente porque é ínsito ao trabalho dos magistrados terem que lidar com os mais variados campos da ciência, o que requer que eles se voltem a estudos que não estritamente jurídicos para julgar, como por exemplo, a psicologia ou a economia. A falta de conhecimento sobre o direito estrangeiro também não impede seu manuseio quando imposto pelo direito privado internacional. Enfim, a falta de "know-how" nestas áreas não é fato impeditivo para exercer o ofício jurisdicional.

Também não se pode falar que a barreira da língua impeça o conhecimento de decisões estrangeiras, pois hoje há literatura crescente sobre o assunto e existem diversos sites dedicados a traduzir decisões de Cortes Constitucionais, como por exemplo o "Institute of Global Law" of Transnational Law ${ }^{79, "}$ mantido pela Universidade do Texas.

Mesmo os Tribunais Constitucionais têm disponibilizado suas decisões em outras línguas, como faz o Supremo Tribunal Federal no Brasil (suas decisões mais importantes estão também disponíveis em espanhol e inglês) e a Corte Europeia de Direito Humanos. De acordo com Sir Basil Markesinis e Jorg Fedtke ${ }^{80}$ é prática comum na Alemanha que os Tribunais solicitem opiniões escritas (wissenschaftliche Gutachten) sobre o direito estrangeiro quando o seu conhecimento seja necessário e muitas livrarias tem inúmeras coleções sobre as opiniões especializadas produzidas por estes experts.

Há, ainda, a possibilidade de o Tribunal estrangeiro recorrer a experts para compreender melhor o direito estrangeiro, da mesma forma que se socorre de especialistas em outras áreas que não jurídicas.

\footnotetext{
${ }^{78} \mathrm{http} / / / w w w . u c l . a c . u k /$ laws/global_law/

${ }^{79} \mathrm{http}: / /$ www.utexas.edu/law/academics/centers/transnational/work_new/

${ }^{80}$ The Judge as Comparatist..., p. 129.
} 
Por fim, saindo um pouco da seara estritamente jurídica, não há como se negar que a postura isolacionista é provinciana e se nega veemente a aprender com os outros. Certamente nenhum campo da ciência se desenvolveu ou evoluiu evitando contato com ideias novas e perspectivas diferentes. Com o Direito não há de ser diferente. Fechar-se como uma ostra não traria nenhum benefício a qualquer ordenamento jurídico. Pelo contrário, aumentar-se-iam as chances de involução ou estagnação em detrimento do melhoramento contínuo do sistema jurídico.

De qualquer maneira, afastadas as críticas dos isolacionistas, seus argumentos apresentam o mérito de chamar atenção para um dos problemas da utilização de direito estrangeiro. Refere-se à constatação de que, muitas vezes, o precedente estrangeiro é algo difícil de compreender, isto é, a tarefa de manusear decisões estrangeiras é algo complexo. Embora tal fato não impeça a utilização do precedente, demonstra que deva ser feita com cautela.

Ademais, a crítica referente ao chamado "cherry picking" ou "forum shopping" também tem o mérito de chamar a atenção para situações em que a Corte apenas busca citar precedentes estrangeiros sem realmente analisar o contexto em que foram produzidos e sem fazer o devido cotejo com o ordenamento doméstico e com a realidade social e cultural do país.

Desta forma, as críticas dos isolacionistas levantam questões que merecerão atenção quando do estudo sobre os critérios para a utilização de precedentes estrangeiros. De fato, o universo da jurisprudência estrangeira é quase infinito e nunca será possível uma aferição global de todas as decisões ou mesmo de uma posição majoritária. Em outras palavras, uma pesquisa quantitativa da jurisprudência estrangeira é inviável ante a magnitude de um trabalho deste tipo. Desta forma, o uso de precedente estrangeiro não deve ocorrer com base em uma análise quantitativa, mas, sim, qualitativa, o que precisará ser levado em conta quando da investigação de critérios para o uso do precedente estrangeiro. 


\subsection{OS MODERADOS}

A corrente moderada é aquela que, ressalvadas as especificidades de cada autor, entende salutar o diálogo entre Cortes, desde que a utilização de jurisprudência estrangeira não seja feita de modo assistemático ou sem qualquer critério.

Pode-se dizer, grosso modo, que os defensores desta corrente veem no intercambio entre Cortes um fluxo de ideias capaz de propiciar um melhor entendimento do próprio ordenamento jurídico em que se está inserido, permitindo a melhora contínua do sistema.

\section{Marcelo Neves ${ }^{81}$ fala sobre o "ponto cego onde apenas o outro} pode ver", no sentido de que a utilização de um precedente estrangeiro permite à jurisdição constitucional enxergar aquilo que ela não seria capaz de ver sozinha, isto é, possibilita-lhe a visão do tema em discussão por uma outra perspectiva. Jeremy Waldron ${ }^{82}$, por sua vez, fala em acúmulo de sabedoria no mundo do Direito e a necessidade de aprendizado com outros ${ }^{83}$. Sujit Choudhry ${ }^{84}$ recorre à ideia de que o contato com visões diferentes sobre o mesmo

\footnotetext{
${ }^{81}$ Transconstitucionalismo, pp.. 295-298.

${ }^{82}$ WALDRON, Jeremy. Foreign Law and the Modern 'Ius Gentium'. In: Harvard Law Review, vol. 119, n. 1, Nov. 2005, p. 133.

${ }^{83}$ Interessantíssimas as palavras de Jeremy WALDRON (ibidem, pp.. 133-143), as quais merecem ser transcritas: "Da mesma maneira (que as ciências), o direito das nações está à disposição dos elaboradores da lei e dos juízes como um corpo de legal insight, lembrando-os que aquele problema particular foi analisado/confrontado anteriormente e que os operadores do direito, como cientistas, deveriam tentar raciocinar sobre o assunto na companhia daqueles que já lidaram com tais problemas".
}

(...)

"Várias vezes tenho recorrido ao exemplo da ciência e da forma de solucionar problemas do conhecimento científico para ilustrar como um consenso no direito estrangeiro pode ser relevante para a tomada de decisões legais nos EUA. Deixe-me demonstrar esta analogia na íntegra. Pense em como esperaríamos que nossas autoridades de saúde pública lidassem com uma nova doença ou epidemia que aparecesse dentro das nossas fronteiras. Seria ridículo afirmar que apenas por este problema ter surgido nos Estados Unidos, devessemos olhar apenas para a ciência americana para resolvê-lo. Pelo contrário, gostaríamos de olhar para o exterior para ver a que conclusões científicas que chegaram os outros povos e quais estratégias foram testadas e aprovadas mutuamente nas práticas de saúde pública de outros países. Podemos pensar na citação da lei estrangeira no caso Roper da mesma forma. A relação entre a pena de morte para menores e os valores consagrados na $8^{\mathrm{a}}$. Emenda é um problema difícil para nós. As complexas questões sobre a dignidade humana e o emaranhado de culpabilidade e responsabilidade são assuntos difíceis. Ao prestar atenção ao que outros juristas têm feito com relação a este assunto ou similares, nós o tratamos como um problema a ser resolvido, em parte, considerando as conclusões da da ciência jurídica como um todo - a empreitada, que muitos sistemas jurídicos compartilham, de lidar com problemas complexos e dar-lhes soluções, conciliando direitos contrapostos que são comuns em temas como este".

${ }^{84}$ Globalization in Search of Justification..., passim. 
assunto estimula a autorreflexão como forma de conhecer e melhorar o próprio Direito. Vicki C. Jackson ${ }^{85}$, por sua vez, menciona que a humildade de se olhar para outros pontos de vista sobre um mesmo tema permite que a interlocução seja mais produtiva. Por fim, Austen L. Parrish $^{86}$, ao analisar o assunto, aduz que a oposição à utilização de material estrangeiro pode ter o efeito oposto de levar os juízes a omitir as reais razões de seu decidir.

Ressalte-se que os autores pesquisados em nenhum momento atribuem ao precedente estrangeiro caráter vinculativo ou transcendental. De maneira geral, entendem o contato com fontes estrangeiras como algo salutar ao desenvolvimento do Direito e do Constitucionalismo. No entanto, estas fontes devem ser utilizadas com cautela e sempre à luz do direito doméstico e das circunstâncias específicas de cada país. Em suma, o direito alienígena é visto como autoridade de referência ou fonte persuasiva, mas jamais como fonte vinculante e isolada.

A posição adotada por estes doutrinadores é, sem dúvidas, aquela que melhor se adéqua às práticas constitucionais atuais, pois embora a Constituição ainda seja vista como um documento único e central nos ordenamentos jurídicos nacionais, é inegável a interação e o intercâmbio entre as Cortes Constitucionais e Internacionais.

Não se pode ignorar o maior contato e a troca de ideias entre elas, o que, indubitavelmente, faz com que haja influências recíprocas. Em outras palavras: ignorar esta realidade em nada colabora com o desenvolvimento do Direito e para o aprimoramento das decisões constitucionais.

Logo, é perceptível que o fenômeno denominado de migração de ideias constitucionais colabora, inquestionavelmente, para a emergência de uma jurisprudência global em determinados assuntos.

A ênfase é mais no intercâmbio de ideias do que reverência/submissão/deferência. As citações recíprocas começam a formar esta

\footnotetext{
${ }^{85}$ Constitutional Comparisons..., p. 128.

${ }^{86}$ Storm in a Teacup..., p. 677.
} 
jurisprudência global, não necessariamente convergente. É o que Bruce Ackerman chama de "Constitucionalismo Mundial"87.

O que esta corrente pretende é justamente lidar com este fenômeno de forma racional, não adotando uma postura baseada no "tudo ou nada". Enxergase o fenômeno e busca-se uma maneira de operacionalizá-lo para dotá-lo de racionalidade e legitimidade.

Não se tem por objetivo meramente importar ou tomar emprestado decisões estrangeiras, mas, sim, analisar e se beneficiar da comparação a ser feita, ou seja, ver a fonte estrangeira como ajuda no raciocínio, na solução de dada controvérsia jurídica.

É importante sublinhar que o uso de material estrangeiro não é algo a ser encarado como um processo aritmético, no qual haverá a soma de decisões que chegarão a um consenso verdadeiro, nem uma teoria progressiva que levará à consolidação de uma jurisprudência mundial sobre determinado tema (embora isso possa acontecer eventualmente). Trata-se, na realidade, mais de um processo de argumentação e intercâmbio entre as diferentes culturas jurídicas, que pode representar consenso ou dissenso ${ }^{88}$.

Ao se reconhecer este caráter mais dialógico e não necessariamente convergente ou progressivo da teoria que se pretende emoldurar, afasta-se esta corrente da ideia de Direito Natural, muito cara aos universalistas.

Jeremy Waldron, ao abordar o tema, salienta a importância do direito estrangeiro e internacional com inesgotável fonte de conhecimento, mas aponta que tal fonte não se confunde com o Direito Natural, mas sim com o denominado "Ius Gentium". Ressalta a diferença entre "Direito Natural" e "Ius Gentium", o primeiro de caráter mais filosófico e idealista (razão humana) e o segundo, não olhando apenas para o lado filosófico,

\footnotetext{
${ }^{87}$ ACKERMAN, Bruce. The Rise of World Constitutionalism. In: Faculty Scholarship Series - Yale Law School Legal Scholarship Repository, Paper 129, 1997, pp.. 771-797.

${ }^{88}$ Vide neste sentido o texto: VESPAZIANI, Alberto. Comparison, Translation and the Making of a Common European Constitutional Culture. 9 German Law Journal, 2008, pp.. 548-549. Disponível em: http://www.germanlawjournal.com/index.php?pageID=11\&artID=955.
} 
mas centrado na realidade jurídica do mundo, mais normativo. Enquanto este último poderia mudar e evoluir, o primeiro é, por definição, imutável ${ }^{89}$.

Tal premissa se coaduna com a história da civilização ocidental, na qual a grande maioria dos países, em que pese às variações em suas estruturas jurídicas, apresenta raízes comuns, as quais foram sendo moldadas conforme a realidade social de cada nação, procedendo-se a muitas aproximações ou afastamentos, mas sempre com trocas de informações e experiências entre elas.

Aliás é sob esta mesma perspectiva que a corrente moderada reconhece que as cortes constitucionais e internacionais enfrentam situações similares, senão idênticas, e que decisões alienígenas podem ser úteis na tomada de decisões constitucionais.

Úteis por dois vieses principais: primeiramente pela possibilidade de se encarar pontos de vista diferentes sobre um mesmo tema, desprendendo-se o juiz de seus preconceitos e ideias, ao mesmo tempo considerando argumentos que antes sequer poderiam cruzar-lhe o pensamento; em segundo lugar, ao permitir a análise das consequências empíricas de determinadas decisões, pois mesmo que as considerações de ordem pragmática não devam ser as únicas a embasar uma decisão constitucional, tal aspecto deve ser levado em conta no processo de tomada de decisão.

Além disso, é necessário perceber que o uso de direito estrangeiro na interlocução entre Cortes Constitucionais não é feito sempre com o fim de se encampar a posição comparada, pois sua finalidade vai muito além da mera acolhida de um precedente. Como bem asseverado por Henk Botha ${ }^{90}$, os sistemas legais substancialmente diferentes são os que permitem aos magistrados ter melhor consciência da contingência de sua própria cultura legal. É justamente a comparação entre sistemas distintos que possibilita aos juízes constitucionais ver que aquilo que é assumido como correto (dogmas), premissas nunca questionadas e que, muitas vezes, tomam fatos como verdadeiros e imutáveis, sem maiores questionamentos. O estudo comparado é salutar à medida que a identificação de semelhanças e diferenças é justamente aquilo que permite perceber o papel contingente da cultura

\footnotetext{
${ }^{89}$ Foreign Law and the Modern 'Ius Gentium', p. 134.

${ }^{90}$ BOTHA, Henk. Comparative law and constitutional adjudication: A South African perspective. In: Jahrbuch des öffentlichen Rechts der Gegenwart, Band 5, 2007, pp.. 569-598.
} 
constitucional sobre o direito em cada país e por meio da qual é possível torna-se mais consciente das contradições inerentes ao sistema, permitindo-se, assim, a busca de resultados mais humanos ${ }^{91}$.

É neste sentido, por exemplo, que Peter Häberle defende o surgimento do "Estado Constitucional Cooperativo", baseado na ideia de um "Direito Comum de Cooperação", oriundo da aproximação entre o direito doméstico e o direito internacional, fundado na ideia de complementaridade e não na ideia de impermeabilidade de sistemas jurídicos. Para o jurista germânico, "O Estado Constitucional aberto apenas pode existir, a longo prazo, como Estado Cooperativo, ou não é um Estado Constitucional" ${ }^{, 92}$. Neste cenário, o direito comparado passa a ter papel relevante para a formatação do Estado Constitucional. Obviamente reconhece o jurista alemão que o "Estado Constitucional Cooperativo" não está completamente formado, conceituado, construído, aparecendo fragmentaria e precariamente, o que não o descaracteriza como norte a ser seguido pelo constitucionalismo.

Por fim, a posição moderada, ao buscar a construção de um método ou uma teoria para a utilização de precedentes estrangeiros, embora não busque a identificação de preceitos universais e transcendentes como os universalistas, tem o mérito de reconhecer, diferentemente dos isolacionistas, o movimento histórico e internacional dos direitos humanos, que influencia não só a legislação doméstica de vários países, como também a decisão das diversas Cortes que lidam com direitos humanos ou fundamentais. Em outras

\footnotetext{
${ }^{91}$ BOTHA frisa que "talvez, nós não devamos ficar tão preocupados com a possibilidade de equívocos. Se o objetivo é melhorar nossa compreensão sobre o nosso próprio sistema nacional por meio de uma analise comparativa, o fato de que algumas nuances do direito estrangeiro e da cultura legal estrangeira podem nos enganar ou passar despercebidos, não é necessariamente ruim. Como sugere Mark Tushnet, a experiência constitucional estrangeira, para ser útil, deve primeiro passar pelas categorias e pelos pressupostos da nossa própria cultura legal. A metáfora do filtro é interessante, à medida que captura tanto o papel da pré-compreensão na interpretação, como o risco de simplesmente reduzir a experiência estrangeira àquilo que nós já sabemos. Para se aprender com a experiência estrangeira, nós precisamos filtrar o que é considerado irrelevante para nosso propósito. Muito do processo de filtrar ocorre no nível de assunções tácitas e pressuposições e não alcança o nível de deliberação consciente. $\mathrm{O}$ que nós podemos aprender com a experiência estrangeira é, portanto, restringido pela enraizada forma de ver e ordenar o nosso mundo. Ao mesmo tempo, entretanto, seria um erro assumir que as categorias e premissas pelas quais são filtradas as experiências estrangeiras são fixas e imutáveis. À medida que ficamos familiarizados com um sistema legal estrangeiro nós nos tornamos mais conscientes dos limites/limitações de nossas próprias categorias e pressuposições ao tentarmos dar sentido a eles e, vagarosamente, nós adquirimos novos meios de pensar sobre problemas familiares. Neste processo, as categorias e pressuposições pelas quais o material legal estrangeiro passa, podem eles mesmos sofrerem adaptações e transformações, as quais podem nos levar a caminhos diferentes da experiência estrangeira e nos permitir vislumbrar aspectos que antes considerávamos não importantes e vice-versa" (Ibidem, p. 596).
}

${ }^{92}$ Estado Constitucional Cooperativo..., p. 10. 
palavras, é atribuída grande importância ao direito internacional dos direitos humanos, no entanto, considerando as peculiaridades das diversas sociedades, tanto do ponto de vista jurídico, como moral e sociológico ${ }^{93}$.

Em síntese, ante a constatação do surgimento de uma rede de comunicação entre os operadores do Direito, entre eles, as Cortes Constitucionais e Tribunais Internacionais, as inegáveis influências recíprocas decorrentes desse intenso contato e o movimento histórico e cultural pela defesa dos direitos humanos e fundamentais, a posição moderada é a única que entende ser possível o estabelecimento de uma metodologia para a utilização de precedentes estrangeiros, haja vista que a corrente isolacionista se opõe radical e infundadamente ao diálogo e a universalista, ao aproximar demais Direito e Moral, de maneira a praticamente fundi-los, prescinde de critérios jurídico-racionais.

1.6 DIREITOS HUMANOS E O DIREITO MATERIAL COMUM NÃO ESCRITO: A EXISTENNCIA DE UM SISTEMA INTERNACIONAL DOS DIREITOS HUMANOS E DE UMA CONSTITUIÇÃO MATERIAL NÃO ESCRITA COMO FUNDAMENTO PARA A UTILIZAÇÃO DE PRECEDENTES ESTRANGEIROS

Optou-se por inserir um tópico "Direitos Humanos e o Direito Material Comum não escrito" neste trabalho, tendo-se em vista que os dois autores brasileiros ${ }^{94}$ que tentaram, de alguma forma, esboçar ou fundar uma teoria para a utilização de precedentes estrangeiros, fizeram-no buscando como fundamento a criação de um "direito constitucional material comum não escrito" combinado com a ideia de maximização dos direitos humanos.

A princípio, as ideias por eles apresentadas pareciam não se identificar com as premissas da corrente universalista e se aproximar daquelas defendidas pela corrente denominada como moderada neste estudo. No entanto, após uma análise mais detida dos trabalhos, percebeu-se que eles se encontram, na realidade, entre os universalistas e os moderados, com algumas particularidades.

\footnotetext{
${ }^{93}$ Nesse sentido: MCCRUDDEN, op. cit. Esse autor diferencia o mero funcionalista do dialógico e diz que a principal contribuição do dialógico é justamente conciliar os direitos humanos com o pluralismo.

${ }^{94}$ André Ramos Tavares e Guilherme Amorim Campos da Silva.
} 
André Ramos Tavares ${ }^{95}$ explicitamente refuta a ideia de Direito Natural, bem como se diz descrente na criação de um Direito Constitucional comum ante a ausência de uma instância superior comum. No entanto, em seguida, assevera que a abertura dos Estados ao mundo e o diálogo entre as Cortes permitirão a redução das "discrepâncias entre os ordenamentos jurídicos, aproximando-se cada vez mais da ideia de um Direito constitucional comum".

Em que pese ao contrassenso, ele advoga que a construção desse "direito constitucional comum" será alcançada, dentre outros meios, pela utilização da jurisprudência estrangeira que deve sempre buscar "promover um incremento do nível de proteção dos direitos humanos fundamentais, desde que seja compatível com os comandos dogmáticos da Constituição nacional". ${ }^{96}$

Afirma que esta tarefa é possível ante a proximidade textual entre as modernas constituições ocidentais e que mesmo "eventual antagonismo entre Constituições pode ser meramente aparente, ou textual, na medida em que boa parte do elemento jurídico é construído por intermédio da atividade interpretativa". ${ }^{97}$

Guilherme Amorim Campos da Silva ${ }^{98}$, por sua vez, considerando o caráter aberto da constituição (aspecto material) combinado com a existência formal de um Sistema Internacional de Proteção dos Direitos Humanos, consubstanciado em uma rede de constituições ligadas por um vínculo comum (a realização dos Direitos Humanos), entende ser legítimo o uso de precedentes provenientes das Cortes que compõem este sistema.

Desta atividade "heterorreferenciada" (evidente influência de Niklas Luhman), ocorreria a integração das diversas normativas nacionais e internacionais de direitos humanos que contribuiria para o surgimento de um direito constitucional convergente, não necessariamente escrito, por ele denominado de "direito constitucional material não

\footnotetext{
${ }^{95}$ Modelos de uso da jurisprudência constitucional..., p. 07.

${ }^{96}$ Ibidem (TAVARES), p. 08.

${ }^{97}$ Ibidem (TAVARES), p. 08.

${ }^{98}$ O uso de precedente estrangeiro pela Justiça Constitucional, passim.
} 
escrito". Em outras palavras, a ligação formal entre estes países permite a aferição de um direito não formal (não positivado).

A busca deste "direito constitucional material não escrito" é mais facilmente compreendida quando, na introdução de seu trabalho, ele se declara adepto do neoconstitucionalismo, justificando como Direito um ordenamento que esteja de acordo com juízos morais. Segundo ele, "as normas somente serão consideradas jurídicas se tiverem um fundamento ético". 99 Também aponta como pressuposto de seu trabalho uma postura jurídicopragmática que coloca a interpretação no centro da produção do direito, refutando o positivismo: "Daí entendemos que a interpretação possibilitada da norma constitucional pelo uso da jurisprudência estrangeira enquadra-se na perspectiva de uma pragmática neoconstitucionalista." 100 .

No decorrer de sua tese, explana acerca da transformação que o Constitucionalismo vem sofrendo com a positivação de valores que confere, no caso brasileiro, ao Supremo Tribunal Federal o dever de adaptar, concretizar e desenvolver os direitos humanos. Não deixa de ser curiosa sua atitude de recusa ao positivismo ao mesmo tempo em que em funda a promoção dos direitos humanos no direito formal ${ }^{101}$.

Na sua perspectiva o mandamento positivo que obriga o Estado a promover os direitos humanos juntamente com a vinculação jurídica do Brasil ao Sistema Americano e Internacional de Direitos Humanos faz com que "a absorção de elementos de precedentes estrangeiros" constitua-se "em prolongamento material do conteúdo jurídico material da norma constitucional" ${ }^{102}$. Neste sentido afirma, ainda, ser obrigatório ${ }^{103}$ o uso de precedentes estrangeiros oriundos do sistema interamericano e internacional de direitos

\footnotetext{
${ }^{99}$ Idem, ibidem, p. 21.

${ }^{100}$ Ibidem (SILVA, Guilherme Amorim Campos da.), p. 22.

${ }^{101}$ Para SILVA, "o movimento de mutação constitucional de um lado e de criação de um direito constitucional material, por outro lado, provém do Direito Formal já estabelecido, positivado, constituindo-se em prolongamento lógico da sua relação de decisões políticas fundamentais, dentre elas, a da prevalência dos direitos humanos" (pp.. 78-79). Em outras palavras, o autor aduz que o próprio direito positivo autoriza a mutação do direito constitucional e aferição dos direitos humanos materiais. Uma constituição formal que numa incorporação dinâmica, absorve aspectos materiais relevantes atinentes a valores previamente consagrados pelo texto formal.

${ }^{102}$ Idem, ibidem, p. 79.

${ }^{103}$ Idem, ibidem, p. 77.
} 
humanos e chega a falar em precedentes vinculantes horizontais ${ }^{104}$. Ao final, defende ele a ideia de uma teoria unificante do denominado direito constitucional material não escrito humano com base no manuseio de precedentes estrangeiros ${ }^{105}$.

Afere-se, pela breve síntese, que os dois autores brasileiros, cada um com suas peculiaridades, baseiam suas teorias nos valores dos Direitos Humanos (aspecto moral), na obrigação constitucional de se potencializar e promover os aludidos direitos e na capacidade transformadora e criadora da interpretação jurídica.

Embora não se negue a importância dos direitos humanos, nem o papel imprescindível da interpretação na criação do direito, a posição dos estudiosos brasileiros se afasta um pouco da postura moderada, ao partir de premissas distintas, que acarretam aumento excessivo da discricionariedade judicial e dificuldades metodológicas consideráveis.

Primeiramente, a posição moderada não reconhece a noção de uma vinculação formal entre as Cortes Constitucionais que as obrigue a citar ou mencionar jurisprudência estrangeira. $\mathrm{O}$ recurso ao direito estrangeiro, ao contrário, é posto como ferramenta autorizada e extremamente útil para a produção de melhores decisões constitucionais. Logo, para os moderados jamais o precedente estrangeiro poderá ser visto como "prolongamento material do conteúdo jurídico material da norma constitucional", nem se pode atribuir-lhe caráter vinculante.

Esta posição é mais adequada porque o precedente estrangeiro simplesmente não pode ser visto como conteúdo material de uma norma constitucional, uma vez que se origina de uma situação que não levou em consideração os aspectos jurídicos, culturais e sociológicos do caso sob análise pelo Tribunal Constitucional. O precedente estrangeiro tem caráter informativo e argumentativo que poderá colaborar, dentre outros elementos, com a proclamação do conteúdo material da constituição, mas não se confunde com esse conteúdo.

\footnotetext{
${ }^{104}$ Idem, ibidem, p. 160.

${ }^{105}$ Idem, ibidem, pp.. 245-247.
} 
Outro ponto em que a teoria do "direito constitucional material não escrito" merece crítica é que mesmo que se reconhecesse a existência formal de uma rede de Cortes Constitucionais que visasse à proteção e promoção de direitos humanos, haveria muita dificuldade em se encontrar uniformidade nesta suposta liga de Tribunais, haja vista que mesmo dentro de países pertencentes aos Sistemas Regionais e Internacionais de Proteção dos Direitos Humanos há diversos entendimentos sobre os mais variados temas.

Ademais, a procura incessante por convergência pode implicar em desconsideração das eventuais diferenças culturais e sociais e, até mesmo, da própria constituição sob análise. Os moderados não negam a possibilidade de convergência, mas, certamente, isto não é uma finalidade maior, mas sim, uma consequência secundária.

Curioso notar que os autores em comento, principalmente Campos da Silva, baseiam-se no aspecto axiológico (moral) do Direito como sendo capaz de proceder a uma unificação (convergência) dos valores ético-jurídicos a serem compartilhados pela sociedade mundial, ou ao menos, pelos países pertencentes ao Sistema Regionais e Internacionais de proteção aos direitos humanos, enquanto que os moderados enxergam os valores como elementos que podem permitir ou não o uso do direito estrangeiro. Registre-se aqui, mais uma vez, que não se desconsidera a possibilidade de convergência ou compartilhamento de valores, apenas não se tem esta convergência como pressuposto ou objetivo primordial.

Por fim, o argumento referente à utilização de precedentes estrangeiros quando estes permitirem a maximização dos direitos humanos gera enormes dificuldades haja vista que, na maioria das vezes, a maximização de um direito humano necessariamente causa a minimização de um outro direito humano. A depender da tradição e dos valores de um Estado no confronto entre direitos humanos ou fundamentais, um deles irá prevalecer. Isto significa dizer que a maximização de um direito humano não traz nenhum parâmetro ou critério para a utilização de direito estrangeiro, pois o seu uso se dará em função do valor escolhido como "vencedor”, não passando de mera retórica, neste caso. 


\subsection{FUNDAMENTOS PARA A UTILIZAÇÃO DE PRECEDENTES ESTRANGEIROS}

Expostas as três posições doutrinárias sobre a possibilidade do uso de precedentes estrangeiros no processo de controle de constitucionalidade, o presente tópico tem por finalidade esclarecer a adesão do trabalho à corrente moderada, apresentando uma síntese das limitações e dos fundamentos que permitem a utilização de material alienígena.

Como já afirmado anteriormente, reconhece-se o caráter indeterminado de muitos preceitos constitucionais, bem como o papel importante que a interpretação tem no manejo destes princípios ou valores.

Postas estas premissas, tem-se como salutar o uso de jurisprudência alienígena para a tomada de decisões de cunho constitucional, desde que o elemento externo não seja o único fundamento que embase a decisão e que o manuseio desse material seja feito com cautela e parcimônia, a partir de determinados critérios.

O precedente estrangeiro não pode ser o elemento central da decisão a ser tomada porque o texto constitucional e seu significado ainda são o eixo central da interpretação constitucional. A desconsideração deste postulado poria por terra o princípio de Supremacia da Constituição.

Todavia, a centralidade da constituição não é circunstância que impeça a manipulação de precedentes estrangeiros. Pelo contrário, a constituição e o constitucionalismo são frutos de anos de história e de trocas de experiências entre os diversos povos.

O uso de material estrangeiro é, de longa data, uma ferramenta extremamente importante para os Juízes Constitucionais, que ao se depararem com casos difíceis recorrem a obras estrangeiras, como aquelas escritas por Aristóteles, Rousseau, Hobbes, Locke, Kelsen, entre outros famosos autores, sem que isso implique em ofensa à constituição, à soberania ou à democracia.

Dada a amplitude da interpretação constitucional, que permite o manuseio de inúmeros elementos, desde o conteúdo axiológico das normas até as consequências de uma decisão constitucional, a utilização de precedentes estrangeiros, quando 
feita de forma criteriosa, pode propiciar a elaboração de decisões mais adequadas, justas e tolerantes.

Com efeito, os precedentes estrangeiros possibilitam ao juiz constitucional ter uma pluralidade de pontos de vista à sua disposição, permitindo uma constante reflexão acerca das alternativas decisórias para determinado caso. É justamente esta interlocução e pluralidade de perspectivas que recomendam o uso de precedentes estrangeiros, na medida em que tal engajamento permite ao julgador vislumbrar todos os ângulos de uma celeuma constitucional e desprender-se de seus preconceitos ${ }^{106}$.

O Direito Constitucional, como ensina Peter Häberle, está passando por uma transformação, na qual o interação entre Cortes Constitucionais tem ganhado relevo. Esta nova postura é bem explicada por Vicki Jackson ${ }^{107}$ :

o direito constitucional pode ser entendido como um lugar de compromisso/encontro entre o direito interno e as fontes e as práticas do direito internacional e do estrangeiro. Desta perspectiva, os intérpretes da constituição não tratam o direito estrangeiro ou internacional como vinculantes ou como normas a serem, presumivelmente, seguidas. Mas também não põem uma tapeira que exclui a fonte e a experiência internacionais. Fontes transnacionais são vistas como interlocutoras, oferecendo maneiras de testar o entendimento de suas próprias tradições e possibilidades, ao examinálas à luz dos outros.

\footnotetext{
${ }^{106}$ Nas palavras de Vicki Jackson: "olhar para o direito transnacional também pode melhorar a tomada de decisão ao expandir as oportunidades de engajamento ético com perspectivas daqueles que tem uma responsabilidade equivalente e aspiram a mesma imparcialidade. Os ministros devem evitar discussões com pessoas estranhas ao tribunal na pendência de um caso, um isolamento que é particularmente pesado para juízes de uma corte de apelo final. Tais regras éticas refletem a aspiração por decisões baseadas na imparcialidade dos juízes, justificada por pontos de vista que melhor entendam o direito. Alcançar este entendimento pode requerer do juiz uma distancia de suas primeiras reações, testando seus preconceitos e sujeitando-os a interrogações razoáveis. Recorrer a decisões de cortes constitucionais estrangeiras pode ser um bom exercício intelectual para a conversação, um teste de fora que pode ser particularmente útil nas mais controversas escolhas. A comparação reflexiva pode, então, oferecer a esperança de mais imparcialidade, na medida em que os juízes se utilizam de decisões estrangeiras como meio de se distanciar e confirmar/afastar suas primeiras reações" (Constitutional Comparisons..., pp.. 118-119).

${ }^{107}$ Idem, ibidem, p. 114.
} 
Neste contexto, conforme leciona Sujit Choudhry ${ }^{108}$, o precedente estrangeiro não busca legitimação em bases normativas, pois o direito comparado é visto como ferramenta para incentivar a autorreflexão constitucional. Não há direito estrangeiro certo ou errado, válido ou inválido, uma vez que ele apenas apresenta uma determinada forma de ver e articular normas e valores.

Vlad Perju ${ }^{109}$ bem salienta esta nova faceta do direito constitucional:

o direito constitucional é visto como um todo singular, sem desconsiderar as diferenças, é como ver os seres humanos e sua diversidade. A possibilidade de ver a experiências dos outros países no controle de constitucionalidade permite-nos desvendar dimensões da humanidade e do significado constitucional que, durante a evolução histórica, um determinado sistema legal ignorou. Considerando-se que o sucesso das reivindicações dos cidadãos depende que a Corte reconheça a dimensão escondida, abertura para experiências de outras comunidades políticas é legitimada pelo próprio ideal de autogoverno de uma democracia constitucional. Da mesma maneira que alguém enxerga outras dimensões de sua própria humanidade por meio do outro, é possível, por trás das fundações do direito constitucional, descobrir um caleidoscópio de experiências de autogovernos nas mais variadas comunidades políticas (...) a abertura constitucional expande as referências normativas e adiciona e renova a pressão por justificação e reflexão dentro do sistema constitucional. (p. 4)

Com efeito, ao realizar este cotejo entre uma situação doméstica e uma decisão alienígena, estará o Tribunal Constitucional realizando um exercício de identificação de premissas factuais e normativas, processo este que independentemente da

\footnotetext{
${ }^{108}$ Globalization in Search of Justification..., pp.. 819-892.

109 PERJU, Vlad. Cosmopolitanism and Constitutional Self-Government. In: International Journal of Constitutional Law (I-CON), Forthcoming; Boston College Law School Legal Studies Research Paper n. 201. Disponível em: http://ssrn.com/abstract=1647069, pp.. 3-4.
} 
similaridade ou divergência, permitirá uma melhor compreensão do próprio sistema jurídico $^{110}$.

Ademais de permitir o contato com pontos de vista distintos e a conscientização acerca do próprio ordenamento jurídico, o estudo de decisões alienígenas também pode ser útil para prever as consequências de determinada decisão ou legislação, pois não há como negar que o aspecto pragmático também é um elemento importante a ser considerado na interpretação constitucional, especialmente quando o próprio texto normativo impõe a consecução de uma série de finalidades.

Em suma, é inegável que a expansão do constitucionalismo propiciou que diversas cortes constitucionais e internacionais passassem a resolver problemas similares e pudessem compartilhar suas experiências comuns, melhorando a qualidade de suas decisões.

Negar a possibilidade de se usar precedentes estrangeiros seria também atentar contra a realidade, haja vista que as influências recíprocas entre as Cortes estão ocorrendo, o que é um fenômeno, ao que parece, irreversível. Uma eventual proibição ao uso do direito estrangeiro somente iria prejudicar a transparência dos julgamentos, uma vez que os magistrados não poderiam expor honestamente as fontes de sua posição.

Desta feita, pode se afirmar que a utilização de precedentes estrangeiros e internacionais por tribunais constitucionais e internacionais é adequada ao atual estágio de desenvolvimento do constitucionalismo, desde que não seja feita de modo submisso ou desordenado, uma vez que tal método proporciona que decisão constitucional seja tomada em face de uma pluralidade de pontos de vista, permitindo uma autorreflexão e autoconscientização sobre o próprio ordenamento, ao mesmo tempo, que, em questões factuais, possibilita a comparação de resultados de determinadas decisões.

\footnotetext{
${ }^{110}$ Nas palavras de Ran Hirschl "a comparação é uma ferramenta fundamental na análise acadêmica. Ela apura nosso poder de descrição e tem papel central na formulação de conceitos ao trazer à luz potenciais similaridades e diferenças entre os casos. Esta finalidade é precisamente o fundamento da terceira (e mais sofisticada) forma de investigação comparativa que busca gerar conceitos ricos e molduras analíticas para um pensamento crítico sobre normas e práticas constitucionais" (HIRSCHL, Ran. Comparative Constitutional Law: Thoughts on Substance and Method. In: Indian Journal of Constitutional Law 2, 2008, pp.. 30-31).
} 


\section{MODELOS DE UTILIZAÇÃO DOS PRECEDENTES ESTRANGEIROS}

O presente capítulo, diferentemente do anterior que se preocupou em analisar as premissas e fundamentos de cada corrente no tocante à possibilidade de utilização de material alienígena, tem por objetivo descrever as possíveis formas de utilização de precedentes estrangeiros pelas cortes constitucionais e supremas cortes.

O foco, aqui, é voltado para a compreensão do fenômeno e das dificuldades que ele traz, mais do que para a análise de argumentos prós e contras. A descrição do fenômeno nas suas mais variadas vertentes será útil para se compreender a problemática do tema como um todo e para o levantamento de possíveis critérios para utilização de precedentes estrangeiros.

Os trabalhos que se debruçaram sobre o tema classificaram-no de diversas maneiras, sendo que o principal critério utilizado foi uma combinação entre o comportamento da corte em relação ao julgado alienígena e sua função/finalidade na decisão constitucional doméstica ${ }^{111}$.

Deste feita, exceto pelo primeiro modelo, de resistência, que em há uma recusa peremptória a qualquer possibilidade de uso de precedentes estrangeiros, todos os demais referendam o uso de alguma forma, ainda que não haja ou esteja clara uma finalidade a ser alcançada.

Além da forma de utilização do precedente estrangeiro como critério de classificação, o tema também foi abordado sobre outras perspectivas interessantes, nas quais o uso do precedente estrangeiro foi classificado de acordo com o grau de dificuldade em justificá-lo ${ }^{112}$ (legitimidade), com a necessidade da Corte em reforçar sua autoridade ${ }^{113}$,

\footnotetext{
111 Vide: TAVARES, André Ramos. Modelos de uso da jurisprudência...; JACKSON, Vicki C. Constitutional Comparisons..., pp.. 109-128; CHOUDHRY, Sujit. Globalization in Search of Justification..., pp.. 819-892.

112 Vide SITARAMAN, Ganesh. The Use and Abuse of Foreign Law in Constitutional Interpretation. In: Harvard Law School Faculty Scholarship Series: Paper 23, 2008. Disponível em: http://lsr.nellco.org/harvard_faculty/23.

${ }^{113}$ HARDING, Sarah K. Comparative Reasoning and Judicial Review. In: Yale Journal of International Law, n. 28, 2003, pp.. 409-464.
} 
bem como com a utilização do precedente estrangeiro para fins de análise empírica/factual ou para fins valorativos ou morais ${ }^{114}$.

Optou-se por adotar como fator de distinção a forma de utilização do precedente vinculada ao comportamento da Corte em relação, por ser o critério de distinção que melhor permite discernir todas as possibilidades de uso do material estrangeiro, ou seja, ele fornece um entendimento abrangente sobre o assunto.

Certamente os demais critérios de diferenciação serão mencionados, pois trazem importantes contribuições para este estudo, principalmente porque demonstram as dificuldades $\mathrm{e}$ as críticas a cada tipo de uso e assim permitem o desenvolvimento de teorias que justifiquem o uso de precedentes estrangeiros.

\subsection{O MODELO DE RESISTENNCIA OU REPULSA}

O modelo de resistência, também denominado de modelo de repulsa, rejeição ou "non usage", é aquele em que a Corte Constitucional dá pouca ou nenhuma abertura às fontes estrangeiras. Em outras palavras, há uma rejeição "a priori" a qualquer elemento alienígena, recusando-se a possibilidade de qualquer diálogo, bem como negando a existência de qualquer vestígio ou possibilidade de existências de normas universais ou comuns.

É evidente que este modelo está umbilicalmente ligado aos isolacionistas mencionados no capítulo anterior (item 1.4) e todas as suas objeções ao uso de precedentes estrangeiros.

Este modelo pressupõe uma autossuficiência do ordenamento constitucional. Como bem explica Sarah K. Harding, parte-se de uma premissa de que a correção/significado de uma norma não está relacionada com fatores externos ao ordenamento jurídico, mas apenas com a fonte de que emana a proposição legal. Se o significado de uma norma depende exclusivamente de referências à fonte legal autorizativa daquela proposição,

\footnotetext{
${ }^{114}$ LARSEN, Joan L. Importing Constitutional Norms from a "Wider Civilization": Lawrence and the Rehnquist Court's Use of Foreign and International Law in Domestic Constitutional Interpretation. In: Ohio Law State Journal, vol. 65, 2004, pp.. 1282-1327.
} 
então, a interpretação é independente e autorreferenciada, não sendo afetada pela visão do julgador (ideal de imparcialidade). Tal fundamento advém da ideia de que a natureza coercitiva do direito demanda uma postura de independência e coerência interna ${ }^{115}$.

Neste sentido, ainda de acordo com a professora norteamericana $^{116}$, a recusa ao uso do material estrangeiro vai de encontro a outras três bandeiras dos isolacionistas, o originalismo e o textualismo ${ }^{117}$, por serem consideradas ferramentas préexistentes ao ordenamento, mas ligadas formalmente a ele, e capazes de conter a atividade judicial, dotando-a de "neutralidade".

Em suma, para a estudiosa norte-americana, ao analisar a Suprema Corte Norte-Americana, a rejeição aos precedentes estrangeiros configura uma busca obsessiva para se reforçar a autoridade da Corte, a qual acredita que o fundamento de sua legitimidade advém de acessar apenas elementos internos para se alcançar o significado da norma constitucional.

Como se afere, este modelo pouco contribui para o surgimento ou aperfeiçoamento de uma sistemática para o uso de precedentes estrangeiros pelas Cortes Constitucionais, haja vista que ele ignora a inegável influência recíproca entre as Cortes Constitucionais, bem como refuta a possibilidade do uso de precedentes estrangeiros. Em suma, este modelo, ou seja, a recusa peremptória e cega ao uso de precedentes alienígenas, nada tem a contribuir com a busca de critérios para sua utilização.

\subsection{O MODELO DE SUBMISSÃO}

Nas palavras de André Ramos Tavares, a prática deste modelo de uso do direito estrangeiro significa que o Tribunal Constitucional age em "total deferência à jurisprudência constitucional estrangeira"118. Outros autores, como Sara K. Harding ${ }^{119}$ e

\footnotetext{
${ }^{115}$ Comparative Reasoning..., pp.. 440-441.

${ }^{116}$ Idem, ibidem, p. 452.

${ }^{117}$ A ideia de que o textualismo se coaduna com o modelo de resistência há de ser vista com reservas. O textualismo prega o apego à literalidade do texto, opondo-se ao uso de material a ele estranho, seja este material doméstico ou estrangeiro. A crítica principal ao textualismo é que este método, muitas vezes, é insuficiente para análise de questões constitucionais.

${ }^{118}$ Modelos de uso da jurisprudência..., p. 03.
} 
Ganesh Sitaraman ${ }^{120}$, denominam este fenômeno como "empréstimos constitucionais" e "aplicação direta", respectivamente.

Em outras palavras, este modelo realiza uma importação acrítica de decisões estrangeiras, o que, inquestionavelmente, pode vir a minar a autoridade da Corte e causar insegurança jurídica. Ao assim proceder, o Tribunal Constitucional abdica de sua função constitucional, permitindo que decisões estrangeiras sejam elementos vinculantes em vez de elementos de argumentação.

Tavares, baseado em Cass Sunstein e em Elise Carpetier, aponta que este modelo é recorrente quando se está diante de uma democracia jovem com pouca experiência constitucional. No entanto, diverge dos aludidos autores estrangeiros ao afirmar que está metodologia é danosa ao ordenamento jurídico, pois a ausência de seletividade pode deslegitimar a atuação da Corte, causar dependência de precedentes estrangeiros e levar ao colapso da Justiça Constitucional $^{121}$.

De fato, a ausência de critérios e absorção impensada de decisões constitucionais podem levar à desfiguração do ordenamento jurídico nacional e afastá-lo da realidade social e cultural do país, sem as quais o Direito perde sentido.

Da mesma forma que o modelo anterior, este modelo em nada colabora para o presente estudo, uma vez que a importação acrítica de decisões alienígenas não contribui para o desenvolvimento do ordenamento jurídico nacional e também em nada permite o aperfeiçoamento do diálogo transconstitucional.

\subsection{O MODELO DECORATIVO}

Chamado de "quoting laguage mode" por Ganesh Sitaraman" ${ }^{122}$, este modelo de utilização de precedentes estrangeiros é meramente ornamental, podendo ser comparado à citação de uma poesia ou de filme durante o julgamento ${ }^{123}$.

\footnotetext{
${ }^{119}$ Comparative Reasoning..., pp.. 409-464.

${ }^{120}$ The Use and Abuse...

${ }^{121}$ Idem (TAVARES), ibidem, p. 08.

122 The Use and Abuse...
} 
Não há qualquer preocupação com o diálogo com as outras Cortes ou com uma efetiva contextualização e cotejo entre a decisão tomada como precedente e o caso sob julgamento. Como bem explica Tavares:

Há uma mera referência desnecessária, referência morta, a elementos não nacionais, como meio de impor soluções previamente engendradas, uma forma de demonstrar conhecimento e autoridade. São usos que efetivamente não têm qualquer deferência ou preocupação dialógica com o material referido. Por esse motivo deve ser concebido como um modelo de referência não decisiva para a tomada de decisão. Prevalecem, aqui, as citações estrangeiras, de maneira textual, sem qualquer demonstração de pertinência, de pesquisa estrangeira ampla, de diálogo com o material colhido ${ }^{124}$.

$\mathrm{Na}$ realidade, este modelo de uso de precedente estrangeiro, em que pese o contrassenso, é um não-uso, pois não realiza qualquer comparação.

Muito provavelmente a maioria das citações realizadas deste modo reflete a busca do julgador em demonstrar erudição e, ao mesmo tempo, legitimação de seu discurso. Virgílio Afonso da Silva ${ }^{125}$ denomina este modelo de uso de "legitimação por deslumbramento", isto é, o argumento estrangeiro teria a função retórica de legitimação do discurso do magistrado, embora, neste caso, não tivesse significativo valor da discussão argumentativa travada.

Considerando-se que este modelo não se consubstancia em um verdadeiro engajamento substancial com o material estrangeiro, ele também não contribui em nada para a busca de critérios, igualando-se neste ponto aos dois modelos referidos anteriormente.

\footnotetext{
${ }^{123}$ The Use and Abuse..., p. 12.

${ }^{124}$ Modelos de uso da jurisprudência..., p. 10.

${ }^{125}$ Interpretação constitucional e sincretismo metodológico. In: Paulo: Malheiros, 2005, pp.. 115-143. (Org.). Interpretação constitucional. São
} 


\subsection{O MODELO DE CONVERGÊNCIA}

Como o próprio nome revela, este modelo decorre da corrente classificada como "universalista", no tópico 1.3. Ela é, logicamente, oposta ao modelo de resistência, realizando uma busca incessante pela convergência, isto é, há uma procura por identificação de normas universais aplicáveis a todos.

Pode se dizer que este modelo é fortemente ligado ao Direito Internacional dos Direitos Humanos e à ideia de Direito Natural, sobretudo ao vago conceito de dignidade da pessoa humana. O discurso transnacional é usado como meio de se encontrar premissas comuns e aplicáveis a todos os seres humanos.

Este modelo, em vez de apenas partir da premissa de que todos os Juízes Constitucionais enfrentam questões comuns para lidar com a jurisprudência estrangeira, vai além, pondo como objetivo encontrar soluções comuns, ou melhor, valores comuns.

Destarte, a jurisprudência estrangeira é vista como fornecedora de elementos normativos para o julgamento de questões constitucionais fundamentais, podendo inclusive vir a derrogar as normas constitucionais. Paolo G. Carozza, defensor deste modelo, bem explica como o precedente estrangeiro deve ser manejado:

Não obstante, grandes tendências internacionais e o desenvolvimento global podem ser evidência do reconhecimento de valores humanos convincentes que transcendem as diferenças entre as civilizações - poderia ser citada a gradual emergência de normas contra a escravidão, como um exemplo histórico deste fenômeno. No mínimo, este diálogo generalizado sugere o compartilhamento de uma consciência/sentimento de ser parte da singular família humana apesar das divisões e diferenças entre as nações.

(...)

Genericamente, então, nós podemos razoavelmente dizer que a força normativa da jurisprudência transnacional é baseada no reconhecimento da humanidade de todas as pessoas. A princípio, a universalidade deste sentimento complementa e apoia o caráter 
transnacional do discurso em prática e consistentemente fornece uma justificação para que as Cortes levem em consideração fontes estrangeiras apesar das restrições constitucionais, históricas, de contexto, políticas e sociais.

$(\ldots)$

Em outras palavras, o ius commune fornece ferramentas que permitem às Cortes julgar casos e justificá-lo mesmo quando contrariem o direito local. Direta ou indiretamente, portanto, o ius comune pode ser visto como um dos fatores constitutivos do direito local, mesmo que os tribunais geralmente justifiquem suas decisões formalmente. ${ }^{126}$

Em síntese, a utilização de precedentes estrangeiros acaba ocorrendo de forma mais livre, em nome dos Direitos Humanos e da Ética, sem maiores análises e sem um cotejo com a realidade jurídico-social da nação que utiliza o precedente.

Há, ainda, uma vertente mais moderada do uso de direito estrangeiro no estilo convergente, por meio da qual se busca aferir um consenso mundial sobre determinado tema, ou seja, a opinião da comunidade mundial teria o condão de influenciar a decisão, quando a norma constitucional em análise fosse indeterminada e aberta.

Exemplo deste modo de uso do direito estrangeiro ocorreu no julgamento do caso Ropers $v$. Simmons, no qual a Suprema Corte Americana julgava a constitucionalidade da pena de morte imposta a menores à época do cometimento do crime em face da oitava emenda constitucional americana, que veda punições incomuns e cruéis.

Justice Kennedy, ao elaborar o voto vencedor, asseverou que "nossa decisão no sentido de que a pena de morte para menores de 18 anos é desproporcional acha guarida na constatação de que os Estados Unidos é o único país do mundo que continua a condenar menores à pena capital" e, adiante, conclui que é "adequado reconhecer a esmagadora força da opinião internacional contra a aplicação de pena de morte a menores (...)". Importante mencionar que, no decorrer de seu voto, Justice Kennedy mencionou

\footnotetext{
${ }^{126}$ CAROZZA, Paolo G .My Friend is a Stranger: The Death Penalty and the Global Ius Commune of Human Rights. Texas Law Review, vol. 81, 2003, p. 1031.
} 
inúmeros países, bem como o Pacto de São José da Costa Rica (Convenção Americana de Direitos Humanos - CADH) e o Pacto Internacional sobre Direitos Civis e Políticos da ONU (ICCPR - sigla em inglês), sendo que o primeiro tratado foi assinado, mas não ratificado pelos Estados Unidos, enquanto que o segundo foi ratificado, mas com reservas quanto ao artigo $6^{\circ}$ (5), justamente aquele que veda a aplicação de pena de morte aos menores de idade.

É perceptível que no referido exemplo o peso do consenso mundial teve forte influência sobre a decisão tomada pelo Tribunal Americano, ainda que outros argumentos também tenham contribuído para a conclusão alcançada, uma vez que recorreu-se a dois instrumentos internacionais que foram explicitamente rechaçados pelo Congresso norte-americano (a CADH e o ICCPR).

Esta maneira de utilização de precedentes estrangeiros parece entender que a existência de consenso dotaria os precedentes estrangeiros de legitimidade, ou seja, a constatação do consenso concederia ao material estrangeiro a autoridade de um verdadeiro precedente, que refletiria a garantia da verdade. $\mathrm{O}$ manejo das decisões convergentes independeria de seu conteúdo e decorreria da concordância entre elas, não ocorrendo uma verdadeira interlocução e reflexão. É o que os autores americanos chamam de "nose-counting".

As duas principais críticas a este modelo são a possibilidade de se ignorar as peculiaridades locais para aplicação de supostas normas universais e a dificuldade de se encontrar um denominador comum sobre muitas questões. Ademais, a possibilidade de se derrogar a Constituição em decorrência de um suposto entendimento universal veiculado em várias decisões é algo bastante controverso.

Mais uma vez, como foco deste modelo não é a interação com as decisões estrangeiras, mas a busca de princípios transcendentais que apontam para soluções comuns ou a aferição de um consenso mundial, permitindo-se, no primeiro caso, o uso livre e fácil da jurisprudência comparativa, e no segundo, desincumbir-se do ônus argumentativo ao recorrer à posição majoritária da comunidade mundial, este modo há de ser visto com reservas. No entanto, como será mais bem explanado adiante, reconhece-se a importância do consenso, mas seu papel é limitado e a adesão deve ser precedida de uma análise cautelosa do caso a ser decidido. 


\subsection{O MODELO DE INTERLOCUÇÃO OU DIALÓGICO}

Este modelo de uso de precedentes estrangeiros é o que decorre do entendimento preconizado pela corrente "moderada", mencionada no tópico 1.4. A abertura ao diálogo é a tônica deste modo de utilização de material estrangeiro, obviamente, sem descuidar das peculiaridades locais/nacionais.

Como já asseverado anteriormente, a jurisprudência estrangeira é vista como ferramenta interpretativa/argumentativa e autoridade persuasiva, que permite ao juiz constitucional ter acesso a inúmeras informações e perspectivas sobre um mesmo tema. Não se trata de simples adoção de jurisprudência estrangeira (submissão) ou busca de uma solução comum (convergência), mas, sim, de fazer um cotejo entre as situações e o direito postos sob análise e se aferir a pertinência de se utilizar um precedente estrangeiro, sempre tendo como paradigma a constituição nacional. A análise do precedente estrangeiro poderá resultar tanto em uso positivo (similaridade) ou negativo (diferenciação), mas sempre terá por fim auxiliar a compreensão do próprio ordenamento jurídico.

Para Sujit Choudhry, grande defensor deste modelo, a utilização de precedente estrangeiro parte da consciência das diferenças constitucionais, sendo esta a sua grande utilidade:

O cerne de interpretação dialógica reside em um reconhecimento do que a reivindicação de diferença constitucional realmente significa. Diferença é um conceito intrinsecamente relativo, uma Constituição só é única por comparação com outras constituições que compartilham alguma qualidade semelhante e com aquelas com as quais compartilham determinada característica (...). Além disso, uma vez que a diferença é definida em termos comparativos, segue-se que uma consciência mais aguçada e uma melhor compreensão da diferença podem ser alcançadas através de um processo de comparação. Desta forma, o uso de jurisprudência comparada, longe de estar em tensão com o compromisso de diferença constitucional, pode, na verdade, 
reconhecer tanto a diferença como a similaridade, aumentando esta consciência, se for utilizado da maneira correta. ${ }^{127}$

Assim, a jurisprudência estrangeira é vista como ferramenta para se chegar a uma conclusão que não necessariamente será convergente. A jurisdição constitucional, ao recorrer a um precedente estrangeiro, irá investigar por que razões a Corte estrangeira alcançou aquele resultado e o que condicionou sua decisão. O direito estrangeiro não é visto como certo ou errado, ele apenas demonstra uma determinada forma de ver e articular normas e valores. Assim, a comparação jurisprudencial pode vir a ser fonte inestimável de informação que auxiliará na tomada da melhor decisão.

No entanto, embora a interlocução ou diálogo constitucional possa ser descrita como um modelo em que a opinião de outra Corte sobre um determinado assunto é levada em conta para possibilitar o autoconhecimento de dado ordenamento jurídico, tal descrição é, ainda, simplista e insuficiente, haja vista que o modelo dialógico pode ser utilizado de inúmeras maneiras e com várias nuances.

De fato, como aduzem Ganesh Sitaramam ${ }^{128}$ e Joan L. Larsen ${ }^{129}$, o uso de precedente estrangeiro pode, no mesmo sentido apontado por Choudhry, servir para ilustrar contrastes entre dois ordenamentos, possibilitando uma melhor compreensão da temática em apreço pelo Tribunal Constitucional, mas também pode ser manejado com o fito de se adotar o raciocínio do julgado paradigma, de reforçar a argumentação da conclusão alcançada, bem como com o objetivo de constatar as consequências de determinada decisão.

No primeiro caso, quando se foca no contraste entre o ordenamento nacional e o estrangeiro, tem-se a utilização da negativa do precedente estrangeiro, isto é, o material alienígena é usado para demonstrar que as premissas e objetivos dos sistemas jurídicos em comparação divergem e, portanto, merecem soluções distintas.

Exemplo desta forma de uso foi a decisão proferida pela Suprema Corte Canadense, no caso Regina v. Keegstra ${ }^{130}$, na qual se discutia a

\footnotetext{
${ }^{127}$ Globalization in Search of Justification..., p. 857.

${ }^{128}$ The Use and Abuse...

${ }^{129}$ Importing Constitutional Norms..., pp.. 1282-1327.

${ }^{130} 1990$ - 3 S.C.R. 697
} 
constitucionalidade de dispositivo do Código Penal canadense que criminalizava o discurso do ódio, no caso, discurso antissemita. No voto vencedor foi aberto um tópico dentro do qual se procedeu a uma detalhada análise da jurisprudência norte-americana sobre o assunto, para, afinal, refutá-la, uma vez que a realidade e as premissas americanas destoavam dos fundamentos constitucionais canadenses.

Outro exemplo de uso dialógico e negativo de utilização de direito estrangeiro é a decisão proferida pela Suprema Corte Sul-Africana em State. v Makwanyane $^{131}$, na qual se discutia a constitucionalidade da pena de morte no país africano. Nesta oportunidade, foi feita uma extensa análise da jurisprudência norte-americana sobre o assunto, a qual considera legítima a aplicação da pena capital pelo Estado e, ao final, foi a posição norte-americana rejeitada por serem as premissas, a história e os valores sul-africanos distintos daqueles da sociedade norte-americana.

$\mathrm{Na}$ segunda hipótese tem-se aquilo que Larsen denomina de empréstimo argumentativo e que Sitaraman chama de argumentação persuasiva, ou seja, a decisão da Corte utiliza como parte de sua fundamentação o raciocínio utilizado em um precedente estrangeiro. De certa forma, o precedente estrangeiro é visto como uma doutrina constitucional, havendo adoção de seus argumentos. Nestes casos, afere-se que os argumentos trazidos em determinado julgado alienígena se coadunam com os ditames constitucionais e é razoável, merecendo ser adotado.

Nestes casos, o precedente estrangeiro pode ser usado independente da existência de consenso, como elemento argumentativo. Todavia, há de se ressaltar que o consenso pode apresentar duas funções nesta situação. Primeiramente, o consenso tem como função apontar para o julgador um caminho que vem sendo seguido por diversas jurisdições constitucionais e tem chance de estar correto. Aqui não se está a falar de se seguir o consenso pura e simplesmente, mas em um engajamento substancial com o consenso, isto é, a convergência é vista como indicador de que a decisão da corte doméstica, ao se afastar do consenso, deve com ele dialogar para deixar claro os motivos do afastamento. Por outro lado, em outras situações, o consenso pode ter a função de reforço lógico, ou seja, servir como confirmação da conclusão alcançada, como sinal de que ela é razoável.

\footnotetext{
${ }^{131}$ Case No. CCT/3/94
} 
Em Lawrence v. Texas, caso em que a Suprema Corte Americana analisava a constitucionalidade da lei texana que criminalizava a relação sexual entre adultos do mesmo sexo, Justice Stevens, ao elaborar o voto majoritário pela inconstitucionalidade da legislação do Estado do Texas, recorreu ao "The Wolfenden Report: Report of the Committee on Homosexual Offenses and Prostitution"132 , relatório este que serviu para a Casa dos Lordes descriminalizar a relações homossexuais no Reino Unido às decisões da Corte Europeia de Direitos Humanos que condenavam Inglaterra e Irlanda a revogaram suas legislações que criminalizavam as relações homossexuais. Nesta oportunidade, o Tribunal Norte-Americano realizou um diálogo que se pautou tanto pelo conteúdo (substância) do material estrangeiro, como pelo consenso.

Por fim, o terceiro caso, denominado de modo empírico pelos aludidos autores ${ }^{133}$, ocorre quando a Corte se utiliza de uma decisão estrangeira para aferir quais as consequências sociais e/ou econômicas de determinada decisão ou legislação. $\mathrm{O}$ intuito é buscar experiências estrangeiras capazes de oferecer um prognóstico sobre determinada situação, como, por exemplo, constatar se determinada legislação restritiva de um direito fundamental foi efetiva na contenção da violência urbana.

Em todas as hipóteses mencionadas a interlocução é inegavelmente salutar, mas foram feitas com cautela, no intuito de se evitar uma transposição inadequada de uma decisão alienígena, uma vez que os precedentes mencionados surgiram em outro ordenamento, em outro ambiente socioeconômico e em outra realidade cultural.

Desta forma, o modelo dialógico, ao se utilizar do precedente estrangeiro, realiza uma cuidadosa identificação de premissas comuns, sejam elas fáticas ou jurídicas, bem como uma fundamentação que demonstre a similitude entre os casos em apreço e a razoabilidade da decisão estrangeira, justificando de forma transparente a adoção do material estrangeiro ou a refuta.

\footnotetext{
${ }^{132}$ Este documento não é tecnicamente um precedente, mas, na realidade, um relatório elaborado pela Comissão de Ofensas Homossexuais e Prostituição que levou o Parlamento Inglês a revogar sua legislação antissodomia ao estabelecer o "Sexual Offences Act 1967".

${ }^{133} \mathrm{O}$ modelo empírico pode estar contido no modelo dialógico, mas também pode ser dele apartado, quando o único objetivo ao se usar o direito estrangeiro for cotejar as consequências pragmáticas da decisão a ser tomada.
} 
É preciso observar, no entanto, que nem sempre o diálogo requer uma similitude completa entre ordenamentos, sociedades e culturas, mas semelhanças entre casos, como um todo ou, ainda, parcialmente. Em outras palavras, não se tem de antemão as situações em que o diálogo pode ocorrer, ele é algo construído à luz do caso sob análise, com suas peculiaridades.

Um exemplo bastante ilustrativo de uma semelhança apenas quanto a determinado aspecto de uma discussão constitucional é o citado por Gary Jeffrey Jacobson, ${ }^{134}$ que faz uma interessante comparação jurídico-social entre a Irlanda e Índia e constata que, apesar de imensas e evidentes diferenças entre essas nações, há uma significante proximidade: ambos os países são ex-colônias britânicas e a religião tem um papel marcante nos dois Estados. Segundo ele, os artigos da Constituição indiana sobre a separação entre Estado e Igreja foram baseados nos artigos constitucionais irlandeses. Em que pese à diferença entre o hinduísmo e o catolicismo, o desafio que se põe é o mesmo: como realizar a aspirações democráticas da constituição e ao mesmo tempo respeitar a existência de um forte e oposto poder religioso? ${ }^{135}$

Como se percebe no exemplo de Jacobson, o uso do modelo de interlocução exige grande abertura, mas também a realização de um cotejo cuidadoso acompanhado de uma fundamentação que justifique o uso da fonte estrangeira, pois, ademais de esclarecer o conteúdo pelo contraste, este modelo pode também recorrer ao precedente estrangeiro como elementos de persuasão na tomada de decisão constitucional.

Por fim, importante mencionar que este cuidado com o devido cotejo e fundamentação se justifica especialmente quando se depara com decisões que adotam jurisprudência estrangeira aduzindo que tal ou qual posição é majoritária ou é aquela dominante nos países civilizados ou desenvolvidos.

\footnotetext{
${ }^{134}$ JACOBSON, Gary Jeffrey. The Permeability of Constitution Borders. In: Texas Law Review, vol. 182, 2004, p. 1800.

${ }^{135} \mathrm{O}$ autor reconhece que a religião católica apresenta uma tendência mais compatível com o constitucionalismo democrático e que a Irlanda não apresenta a desigualdade social presente na Índia. No entanto, as fortes concepções religiosas também restam difíceis de reconciliar com inúmeros direitos (aborto, métodos contraceptivos, homossexualismo, entre outros), especialmente no contexto de progressiva integração da Irlanda na UE. Trata-se de um grande dilema judicial (idem, p. 1800).
} 
Como já dito, embora o eventual consenso ou tendência sobre determinado assunto seja algo que possa iniciar uma interlocução, não deve ser ele a justificativa para o uso de um precedente estrangeiro ${ }^{136}$ para se evitar, como já dito, a transposição impensada de material estrangeiro para o ordenamento doméstico. Esta é uma cautela que vale principalmente para países em desenvolvimento, como o Brasil, que muitas vezes procedem a uma importação acrítica de modelos jurídicos alienígenas que em nada melhoram o sistema jurídico ${ }^{137}$. O foco deve ser sempre na análise da argumentação e do raciocínio levado a cabo no material estrangeiro e não no resultado dos precedentes ou na jurisprudência dominante.

Portanto, pode-se dizer que o modelo de interlocução ou diálogo pressupõe grande abertura ao diálogo entre as jurisdições constitucionais e também entre elas e os Tribunais Internacionais, com o fito de trocar ideias, conceitos e soluções, que podem servir tanto para conhecimento do próprio ordenamento por meio da conscientização e das similitudes e diferenças, ou como elemento persuasivo ou empírico na tomada da decisão constitucional. Nestes dois últimos casos, a utilização de precedentes estrangeiros deve ser realizada de maneira cuidadosa, sempre tendo em vista a constituição nacional e os aspectos sociais, econômicos, políticos e culturais envolvidos na questão sob análise.

\subsection{O MODELO PRAGMÁTICO}

O modelo pragmático é aquele em que o precedente estrangeiro é visto como elemento empírico a ser levado em consideração no processo de tomada da decisão constitucional. Cumpre observar que este modelo não tem qualquer ambição normativa ou finalidade de diálogo. Diversamente do modelo interlocução que enxerga que o uso de precedentes estrangeiros engloba o aspecto pragmático, entre vários outros aspectos, o modelo pragmático apenas admite o recurso à material alienígena para aferir as consequências de determinada decisão constitucional.

\footnotetext{
${ }^{136}$ Sobre o assunto vide: LARSEN, Joan L. Importing Constitutional Norms...; SITARAMAN, Ganesh. The Use and Abuse...;DAMMANN, Jens. The Role of Comparative Law in Statutory and Constitutional Interpretation. In: St. Thomas Law Review, vol. 14, p. 513, 2002.

${ }^{137}$ Para uma visão crítica sobre o tema vide: MONTORO, Franco. Filosofia do Direito e Colonialismo Cultural. In: Revista de Informação Legislativa, Brasília: Senado Federal, Ano X, n. 37, jan/mar, 1973, pp.. 4-20.
} 
De acordo com este modo, o uso de direito comparado ocorre em situações nas quais a Corte Constitucional precisa aferir as consequências ou os efeitos de uma legislação ou de uma decisão constitucional. Ela parte da premissa de que a experiência de outros países pode ser útil para a solução de problemas jurídicos que demandam análise dos efeitos da legislação e das decisões constitucionais sobre a sociedade e sobre o ordenamento jurídico.

Em suma, o elemento factual estrangeiro é instrumento que ajuda a definir se a legislação adotada realmente alcança o fim a que se propõe, bem como, pode auxiliar na ponderação de valores que envolva questões pragmáticas.

É como se o mundo fosse um laboratório à disposição para analisar os testes já efetuados pelos demais “cientistas jurídicos”. Enfim, uma luz empírica que pode auxiliar na tomada de decisões.

Três são os exemplos mais citados pela doutrina americana em que se procedeu a este tipo de uso: Miranda v. Arizona ${ }^{138}$, Washington v. Glucksberg ${ }^{139}$, e Prinz v. United States ${ }^{140}$.

No primeiro deles, discutia-se se a confissão de um crime feita por meio de um interrogatório policial sem se comprovar que o investigado foi informado que tinha direito a um advogado e podia permanecer em silêncio tinha validade no processo criminal posterior à investigação. A questão posta era conferir se o direito de interrogatório em conjunto com um advogado dificultaria a aplicação da lei penal. Para analisar o caso, a Suprema Corte Americana recorreu ao direito estrangeiro, em especial Inglaterra, Índia e Escócia, e aferiu que a garantia em comento, presente nestes países, não teve como consequência dificultar a aplicação da legislação penal e que, portanto, o direito ao advogado e ao silêncio era constitucional.

No segundo caso, Harold Glucksberg, um médico em conjunto com outros três e em litisconsórcio com mais três doentes terminais, apresentou uma ação pleiteando a inconstitucionalidade da lei do Estado de Washington que vedava o suicídio

\footnotetext{
138384 U.S. 436 - 1966

139 521 U.S. 702 - 1997

${ }^{140} 521$ U.S. $898-1997$
} 
assistido, pois, para eles a mencionada legislação ofendia a cláusula do devido processo legal e da décima-quarta emenda. Tanto Chief Justice Rehnquist, como Justice Souter recorreram à experiência holandesa sobre o assunto (a eutanásia é permitida no país europeu), para demonstrar que os próprios holandeses estavam divididos quanto à mencionada legislação, pois havia fortes indícios de que a tentativa de se conceder uma morte digna para os pacientes terminais estava permitindo que pessoas doentes praticassem o suicídio sem realmente concordar ou estar consciente de sua decisão.

Por fim, no ultimo caso mencionado, discutia-se se uma lei federal, que impunha a agentes estaduais a obrigação de implementar política federal de armas, ofendia o princípio federativo. Embora a corte tenha declarado a inconstitucionalidade da referida legislação federal, Justice Breyer, no voto minoritário, invocou em suas razões exemplos do federalismo alemão, suíço e europeu, aduzindo, em síntese, que a experiência deles demonstrava que a implementação de políticas federais por agentes locais, ao contrário de violar a ideia de federação, reforçava a autoridade independente de cada comunidade, bem como auxiliava na salvaguarda das liberdades individuais.

Obviamente estes três julgados poderiam se encaixar no modelo dialógico, tratado no tópico anterior, todavia, tendo-se em vista que o uso do direito estrangeiro se deu primordialmente em função das consequências ou efeitos de determinada legislação e não com um intuito de análise argumentativa, optou-se por tratar deste modo neste tópico, em apartado.

\subsection{O MODELO GENEALÓGICO}

O modelo genealógico pressupõe uma relação de ascendência e "irmandade" entre sistemas jurídicos, como por exemplo, a relação entre os ordenamentos jurídicos canadense e norte-americano ante a ascendência do Império Britânico sobre suas excolônias. Neste caso, a autoridade do direito invocado independe do conteúdo, relacionando-se com a noção de autoridade de um suposto direito comum anterior. 
Segundo Sujit Choudhry ${ }^{141}$, este modo de interpretação difere dos modelos universalista e dialógico. Para o universalista, o uso da jurisprudência comparada é justificada pela busca de princípios de política e moral universais. Uma fonte estrangeira é exatamente valiosa fonte de informação quanto ao seu aspecto substantivo. Portanto, é uma interpretação "dependente do conteúdo" (orientação antipositivista). Já o modo dialógico também lida com o aspecto substantivo da jurisprudência comparada, mas o faz mais para proceder a uma autorreflexão do para que encontrar a solução que melhor resolva o caso. Neste modo os princípios plasmados na jurisprudência comparada não são necessariamente o aspecto mais importante. Mas ainda sim a Corte precisa fazer um balanço dos mesmos princípios, para explicar seus pontos de partida de maneira coerente.

Além da perspectiva de ascendência comum apontada por Choudhry, o modelo genealógico também seria aplicável nas situações em que, embora não haja uma ascendência comum entre os ordenamentos jurídicos, a norma ou o instituto legal sob análise foi importado legislativamente de outro país.

Assim, por exemplo, no caso da repercussão geral, acolhida no sistema constitucional brasileiro por meio da emenda constitucional $n^{\circ} 45 / 2004$, poderia se recorrer ou, ao menos analisar, a jurisprudência norte-americana sobre o "writ of certiorari", que serviu de inspiração ao modelo brasileiro. Desta feita, a relação histórica e conceitual entre normas e institutos permitira uma enriquecedora análise de institutos similares em jurisdições distintas.

\subsection{O MODELO ALEATÓRIO OU DE BRICOLAGEM}

Por fim, tem-se, ainda, o modelo aleatório, no qual a utilização de material estrangeiro ocorre randomicamente, isto é, há menção ao uso de direito alienígena, mas não se consegue localizar uma justificação ou aferir a pertinência de seu uso. São casos em que resta patente a ausência de qualquer preocupação em justificar o uso de precedentes estrangeiros ou de manuseá-los de maneira lógica e coerente.

\footnotetext{
${ }^{141}$ Globalization in Search of Justification..., p. 870.
} 
Este modelo difere do modelo decorativo na medida em que os precedentes invocados afetam de alguma forma o resultado alcançado pelo julgador, contudo o leitor da decisão não consegue enxergar como e em que medida o elemento alienígena afetou a decisão.

A ocorrência deste modelo pode derivar tanto de uma falha do julgador ao justificar seus argumentos (ausência não intencional de fundamentação) ou quando o magistrado intencionalmente omite os motivos que o levaram a recorrer a precedentes estrangeiros, pois, talvez, seriam eles inaceitáveis e demonstrariam que a decisão foi tomada com forte base em preferências pessoais plasmadas nos precedentes invocados.

Em qualquer das hipóteses aludidas este modelo em nada contribui para a criação de uma metodologia do uso do direito estrangeiro, seja por omitir sua fundamentação, seja por resultar em mero decisionismo. 


\section{CRITÉRIOS E MÉTOdO PARA A UTILIZAÇÃO DE PRECEDENTES ESTRANGEIROS}

O presente capítulo tem por fim delinear as possibilidades de interações entre o julgamento doméstico do tribunal constitucional e os precedentes estrangeiros, bem como estabelecer a maneira como esta interação deve ocorrer para ser considerada legítima.

Assim, optou-se, primeiramente, por fazer uma análise mais detida de alguns critérios encontrados na pesquisa bibliográfica, para encampá-los ou afastálos, para depois, em tópico específico, apontar aqueles que foram aceitos e outros que serão sugeridos por este trabalho.

Posteriormente, em item subsequente, será abordada a forma de realizar o cotejo entre o caso concreto doméstico e o precedente estrangeiro.

Logo, pode se dizer que o presente capítulo se divide em duas partes bem claras: a primeira delas visa apontar quais são os critérios que permitem a interlocução entre as jurisdições constitucionais e a segunda apresenta uma metodologia para o manuseio desses critérios pelo magistrado constitucional.

\subsection{PRELIMINARMENTE: NECESSIDADE DE PREVISÃO CONSTITUCIONAL OU AUTORIZAÇÃO IMPLÍCITA?}

Antes de se adentrar a temática relativa aos possíveis critérios para o uso de precedentes estrangeiros, é necessário discutir se a mencionada utilização requer uma autorização positiva da constituição ou se tal permissão é implícita.

Obviamente já foi debatido e demonstrado a possibilidade e as vantagens do uso de precedentes estrangeiros nos tópicos anteriores, bem como a sua compatibilidade com os métodos atuais de interpretação constitucional. Todavia, a questão se 
põe porque há uma nação, a África do Sul, cuja constituição apresenta uma disposição expressa neste sentido ${ }^{142}$. Confira seu artigo $39^{143}$ :

39. A interpretação da Carta de Direitos Fundamentais:

Ao interpretar os direitos fundamentais, a corte, o tribunal ou o fórum:

a) deve promover os valores que alicerçam uma sociedade aberta e democrática baseada na dignidade humana, na igualdade e na liberdade;

b) deve considerar o direito internacional; e

c) pode considerar o direito estrangeiro (grifou-se).

A forma como o documento constitucional sul-africano trata o assunto contrasta fortemente com a Constituição norte-americana, que é lacônica sobre o tema e sequer consagra o tão difundido valor da dignidade da pessoa humana.

Frente a este contraste muitos autores americanos aduzem que sua carta de direitos não permite o manuseio de direito estrangeiro para sua interpretação, pois tal autorização deveria ser expressa.

Contudo, mais vez, esta alegação merece reparos, haja vista que tais autores desconsideram os diferentes momentos de promulgação das aludidas constituições, a história dos dois povos, bem como o desenvolvimento do constitucionalismo nestes últimos dois séculos.

Não se pode esquecer, antes de mais nada, que a Lei Maior norte-americana foi elaborada há mais de duzentos anos por um povo que lutava para ser livre

\footnotetext{
${ }^{142}$ A Constituição Federal de 1988, como será abordado no capítulo 4, não faz menção a qualquer método de interpretação, inclusive sobre o uso de precedentes estrangeiros para fins de interpretação constitucional. No entanto, a história legislativa brasileira aponta para uma abertura. O assunto será melhor analisado oportunamente.

${ }^{143}$ Segundo Andrea Lollini (Legal argumentation based on foreign law: An example from case law of the South African Constitutional Court. In: Utrecht Law Review, v. 3, n. 1, June 2007, pp.. 60-74), três foram os motivos para adoção deste dispositivo constitucional pela então recém-nascida democracia sul-africana: a) necessidade de engajar na comunidade internacional de proteção dos direitos humanos após décadas de apartheid, onde houve repetidas e continuas afronta ao direitos humanos; b) ajuda internacional para a nascente democracia e o novíssimo sistema constitucional, ou seja, a necessidade de achar pontos de referência; c) a consciência de que introduzir o controle de constitucionalidade no país demandaria um período de aprendizado legal e cultural.
} 
da metrópole inglesa no momento em que o constitucionalismo era um movimento ainda incipiente, que estava dando seus primeiros passos. Em oposição, a constituição sul-africana foi promulgada há menos de vinte anos e simboliza um momento histórico de transição que tem por objetivo deixar seu passado de desigualdade e racismo para trás.

Ademais, quando os Estados Unidos apresentaram ao mundo sua constituição, não havia modelos a se espelhar, nem cortes constitucionais que as protegesse. Diferentemente, quando a carta de direitos sul-africana foi promulgada, o constitucionalismo, apesar de alguns percalços, já havia se estabelecido e a existência de uma "rede" de cortes constitucionais estrangeiras já era uma realidade avançada.

Por fim, ainda não se pode ignorar que o avanço tecnológico nestes duzentos anos foi impressionante e mudou profundamente as relações entre as nações e, inquestionavelmente, alterou a relação entre o Direito e o Estado, bem como entre os atores jurídicos.

São justamente estas alterações, já abordadas nos tópicos anteriores, que demonstram que a autorização expressa no texto constitucional é desnecessária, uma vez que a utilização de precedentes estrangeiros aqui proposta baseia-se na noção de diálogo e não em submissão. Como já asseverado, o contato com outras culturas jurídicas é inevitável e vetar o uso de um elemento de argumentação valoroso como o material estrangeiro em nada colabora para criação de métodos que possam analisar a influência de precedentes estrangeiros nas decisões constitucionais.

Além das mudanças advindas do desenvolvimento histórico do constitucionalismo e dos inquestionáveis avanços tecnológicos, é importante constatar que, em regra, as Constituições não estabelecem métodos de interpretação ou elencam uma ordem de preferência entre eles. Tradicionalmente a sistematização dos possíveis métodos de interpretação é deixada a cargo da doutrina, muito provavelmente ante a complexidade desta atividade que não pode ser capturada pelo direito positivo.

Considerando-se a utilização de precedentes estrangeiros como um método ou uma ferramenta interpretativa, não se pode deixar de repetir as palavras de J.J. Canotilho, que baseado em Peter Häberle, chama a interlocução entre as cortes constitucionais 
e o intercâmbio de ideias constitucionais de "quinto método de interpretação constitucional" a ser considerado juntamente com os tradicionais métodos, quais sejam, gramatical, lógico, histórico e sistemático. Se estes métodos, para sua aplicação, independem de expressa previsão legal, porque a prática comparativa também precisaria?

Por outro lado, também é de fácil constatação que a exigência de previsão expressa ou suposta vedação ao uso de precedentes estrangeiros pela jurisdição constitucional, teria o efeito nocivo de impedir os jurisdicionados de saber os reais motivos que levaram sua corte a julgar de determinado modo.

Em outras palavras, vetar o uso de direito estrangeiro em uma época em que a globalização aponta para uma aproximação inescapável dos atores jurídicos é colaborar para que os magistrados produzam decisões escondendo seus reais fundamentos, não se permitindo uma discussão democrática acerca dos caminhos a serem tomados por um país na interpretação de sua lei maior.

Desta forma, o presente trabalho entende que não há necessidade de autorização explícita para a utilização de material alienígena na tomada de decisões constitucionais, a qual deve ser sempre feita de maneira criteriosa. Também entende que a vedação ao referido uso traria mais prejuízos do que benefícios ao ordenamento jurídico, sendo que norma neste sentido correria o risco de nascer morta, ante sua impossibilidade de controlar os meios pelos quais os magistrados alcançam suas decisões, colaborando apenas para que sejam elas prolatadas de forma não transparente.

\subsection{O PONTO DE PARTIDA: O TEXTO CONSTITUCIONAL DOMÉSTICO E SUA} ABERTURA

Embora este item possa parecer desnecessário, ele não é. Há autores, principalmente internacionalistas, como Luis Cláudio Coni ${ }^{145}$ e Antônio Cançado Trindade $^{146}$, que defendem a prevalência do direito internacional sobre o direito interno, ou

\footnotetext{
${ }^{144}$ CANOTILHO, op. cit., p. 1224.

145 A internacionalização do Poder Constituinte...

${ }^{146}$ Voto proferido na Opinião Consultiva (OC) n. 18/03 de 17 de Setembro de 2003, na Corte Interamericana de Direitos Humanos.
} 
seja, as normativas internacionais devem ou podem prevalecer sobre o texto constitucional quando com ele se confrontarem.

Por este raciocínio, mesmo que a decisão de uma corte constitucional não se consubstancie tecnicamente em direito internacional, poderiam elas ser usadas para transformar ou alterar o texto constitucional quando fossem consideradas decisões que aplicam o direito internacional, quando revelam princípios comuns a todos os povos ou, ainda, quando consagram valores que refletem o ordenamento jurídico internacional.

Assim, havendo este entendimento, houve-se por bem explicitar que o uso do direito estrangeiro, nos termos aqui propostos, tem como ponto de partida o texto constitucional doméstico $^{147}$ que, em condições de normalidade, jamais pode ser desconsiderado, pois isto, sim, acarretaria ofensa à democracia e ao princípio da supremacia constitucional.

Parte-se sempre do texto e das possibilidades interpretativas que ele abre. Logo, tem-se como pressuposto para a utilização de precedentes estrangeiros que ou o texto constitucional é lacônico sobre determinado tema, ou é aberto, comportando mais de uma interpretação.

Em outras palavras, a análise do texto constitucional é imprescindível, pois é a partir dele que, em um primeiro momento, será analisada se há a possibilidade de se recorrer a material alienígena e em qual extensão. Note-se que não se está a falar em fechamento constitucional, mas de se estabelecer um ponto de partida que sempre norteará o caminho a ser trilhado até o resultado da decisão constitucional.

Assim seria muito grave, por exemplo, se uma dada constituição impedisse expressamente a realização do aborto e a Corte Constitucional, incumbida de zelar pela referida constituição, permitisse a realização do aborto com base unicamente na jurisprudência da Suprema Corte Americana, que, no caso Roe v. Wade $e^{148}$, decidiu pela constitucionalidade da interrupção da gravidez. Agir desta forma, além de violar a vontade do Poder Constituinte, implicaria na total desconsideração de inúmeros elementos que

\footnotetext{
${ }^{147}$ Quando aqui se fala em texto constitucional não apenas se quer dizer sua literalidade sintática ou semântica, mas também seu significado dentro do ordenamento jurídico doméstico.

148410 U.S. 113 - 1973
} 
influenciaram a elaboração desse dispositivo, uma vez que a constituição reflete inúmeros aspectos de um povo, como a cultura, a política e os valores morais.

Portanto, conforme as bases apresentadas nos tópicos anteriores, o uso de precedentes estrangeiros no modo dialógico requer que o metafórico diálogo ocorra de maneira a respeitar a essência de cada ordenamento engajado no diálogo, não podendo ser utilizado como ferramenta que objetive afastar decisões constitucionais tomadas de maneira democrática e que se apresentam claras e evidentes.

\subsection{A QUESTÃO DO CONSENSO MUNDIAL, O PROBLEMA DA SELETIVIDADE DE FONTES ESTRANGEIRAS E DAS CORTES ELEGÍVEIS.}

Alguns autores, como André Ramos Tavares ${ }^{149}$, Cass Sunstein ${ }^{150}$ e Eric Posner ${ }^{151}$, defendem, com base no Teorema do Júri do Marquês de Condorcet, que o direito estrangeiro apenas deveria ser utilizado quando houvesse um consenso mundial sobre determinado assunto.

Esclareça-se, de antemão, que estes autores ao usarem o termo consenso, o fazem de maneira imprópria, uma vez que não estão a falar sobre um acordo, como se as partes alcançassem um entendimento, uma composição de vontades, mas, na realidade referem-se ao termo no sentido de maioria, isto é, o "consenso" é aqui tratado como a posição da maioria sobre determinado assunto ou problema jurídico. Em que pese à impropriedade do termo, optou-se por mantê-lo por ser o mesmo amplamente usado.

Aqueles que defendem o consenso como critério invocam como fundamento a ideia condorcetiana de que quanto maior o grupo de pessoas a tomar uma decisão, maior a probabilidade de que esta decisão seja correta. Em outras palavras, a chance de correição tende a aumentar em função da elevação do número de participantes no processo de tomada de decisão.

\footnotetext{
${ }^{149}$ Modelos de uso da jurisprudência...

${ }^{150}$ A Constitution of many minds...

${ }^{151}$ SUNSTEIN, Cass R. \& POSNER Eric. The Law of Other States. In: 59 Stanford Law Review, 2006, p. 131.
} 
Ainda segundo o teorema condorcetiano, as condições para que o grupo alcance a resposta correta são em síntese: a) que o voto de cada um reflita um julgamento livre e independente, não impregnado de preconceitos; b) que o votante tenha informações privadas que não provenham de efeitos cascatas, ou seja, não se reflitam mera reprodução acrítica de informações, c) que as situações (questões) em comparação sejam similares $^{152}$.

Transpondo-se a teoria condorcetiana para este trabalho e valendo-se da explicação de Cass Sunstein e Eric Posner, tem-se que as

práticas de outros estados fornecem informação útil quando três condições são alcançadas: a prática reflete o julgamento da população afetada ou de seus legisladores/julgadores, o outro estado é suficientemente similar e a decisão tomada pelo outro estado reflete uma prática independente ${ }^{153}$.

Assim, adotando-se este critério e estando presentes os seus requisitos, tem-se que, se um maior número de cortes assume determinada posição, há maiores chances desta posição estar correta.

Embora esta tese pareça bastante sedutora, tanto suas premissas e sua condições, como sua implementação são bastante problemáticas.

Primeiramente, no que concerne a suas premissas, não se pode olvidar que o teorema condorcetiano é bastante criticado e carece de comprovação. A uma porque se apoia na controversa ideia de "resposta correta" para a solução de problemas jurídicos. Ademais, certamente não se pode dizer que o simples aumento no número de votantes eleva potencialmente a chance de acerto da decisão, pois, se assim fosse, o direito constitucional sequer teria que se voltar aos estudos dos problemas contramajoritários, pois a democracia, por si só, seria instituto garantidor da resposta correta. A duas, porque, ao dotar o precedente estrangeiro de autoridade em função de uma posição majoritária, este entendimento minimiza indevidamente o papel do elemento estrangeiro na argumentação constitucional, bem como empobrece as potencialidades do diálogo entre cortes como aqui proposto. Por fim,

\footnotetext{
${ }^{152}$ SUNSTEIN, A Constitution of many minds..., p. 09.

${ }^{153}$ The Law of Other States..., p. 136.
} 
ao não permitir a conversa constitucional em razão de mera ausência de consenso, esta posição impede que diálogos salutares entre cortes constitucionais venham a ocorrer, pois o engajamento na conversa constitucional não é apenas útil em situações de consenso, podendo ser, também, extremamente benéfica mesmo quando realizada apenas entre duas cortes, ainda que seja para afastar o precedente discutido (uso negativo).

Em segundo lugar, caso ainda se optasse em adotar este critério para a utilização de precedentes estrangeiros, seria praticamente impossível se aferir as condições elencadas pelos autores que defendem a teoria em comento, principalmente no que se refere às condições de livre convencimento, ausência de preconceitos e ausência do dito efeito cascata. Ademais, checar se todos os tribunais constitucionais e supremas cortes que alcançaram o mesmo entendimento preencheram os mencionados requisitos para aplicação da teoria parece ser uma tarefa hercúlea, cujo esforço para realização não valeria a pena.

Em terceiro lugar, mesmo que todas as condições fossem preenchidas, a aferição do consenso pode não ser tão fácil, pois cada decisão pode apresentar diferentes nuances e nem sempre é uma tarefa simples coletar a posição de mais de duzentos países sobre um mesmo tema.

Há de se reconhecer, todavia, que os autores mencionados sugerem que a pesquisa se restrinja a um grupo pequeno de países, em geral às democracias ocidentais mais desenvolvidas ${ }^{154}$. No entanto, esta restrição estaria em contradição com as próprias premissas da teoria que prega a maior chance de acerto em função do aumento considerável do número de votantes. Além disso, tal restrição poderia, eventualmente, impedir comparações salutares como aquelas entre nações tão distintas, como Irlanda e Índia, já mencionada no tópico 2.5. São situações em que, num primeiro momento e a partir de uma

\footnotetext{
${ }^{154}$ Rex D. Glensy, em artigo intitulado "Which countries count? Lawrence vs. Texas and the selection of Foreign Persuasive Authority" (In: Virginia Journal of International Law, vol. 45, 2005, pp.. 357-449), chega a aduzir que nem todas as nações são aptas a fornecer material para a Suprema Corte Americana, ou seja, que a comunidade global de cortes não inclui todas as cortes de todos os países. Ela fala em materiais "inadequados" e afirma que é preciso afastar a ideia do direito internacional de que todas as nações são iguais. $\mathrm{O}$ autor chama esta ideia de mera quimera. (p. 406)
} 
visão apenas macro, os países parecem não ser semelhantes, mas a análise do caso concreto pode vir a gerar uma interconexão apta a produzir uma comparação produtiva ${ }^{155}$.

Demonstrada como a escolha do consenso da comunidade mundial como critério para a utilização de precedentes estrangeiros pode ser inadequada e problemática, resta enfrentar o problema oposto, denominado pelos norte-americanos de "nose-counting" ou "forum-shopping”, isto é, o uso seletivo do material alienígena ${ }^{156}$.

Ao que parece, os autores que defendem o consenso como critério, queriam, justamente, responder às críticas acerca do uso seletivo de precedentes estrangeiros, ou seja, legitimar seu uso com base em uma autoridade decorrente de uma posição majoritária na comunidade mundial, uma espécie de "democracia global dos Estados", o que, como já visto, é bastante criticável.

Todavia, no sentir deste trabalho, a questão da seletividade não pode ser realmente vista como um problema. Primeiramente porque a polêmica da seletividade não se restringe unicamente ao uso de precedentes estrangeiros, como já mencionado no item que trata da corrente isolacionista, mas pertence a um universo mais amplo, referente às fontes formais e informais que podem ser consideradas e manuseadas na interpretação e aplicação do Direito. Em segundo lugar, porque a forma de interlocução entre as Cortes Constitucionais pode variar, ou seja, os elementos de conexão que permitem a comparação são os mais variados e a seletividade ocorre justamente em função das inúmeras possibilidades de comparação.

Assim, por exemplo, no caso Ropper v. Simmons ${ }^{157}$, a crítica feita pelo Justice Scalia à seletividade de fontes supostamente ocorrida no voto majoritário carece de fundamentos. Naquele caso, em que se discutia a aplicação de pena de morte a

\footnotetext{
${ }^{155}$ Note que há dois tipos de consenso principais: aquele amplo referente à totalidade dos Estados e aquele mais restrito, relacionado apenas a um pequeno número de países. Obviamente inúmeros outros parâmetros para mensurar consenso poderiam ser levados em conta, como por exemplo, o consenso dos países europeus, dos países latino-americanos, das democracias ocidentais, entre outros.

${ }^{156}$ Michel D. Ramsey, em um artigo denominado "International Materials and Domestic Rights: Reflections on Atkins and Lawrence" (In: The American Journal of International Law, vol. 98, n. 1, Jan. 2004, pp.. 69-82), fala que o uso de direito estrangeiro, para ser legítimo tem "tomar o amargo com o doce" ("take the bitter with the sweet"), no sentido de que não se pode invocar direito estrangeiro apenas quando se tiver por intuito a ampliação de direitos (e não a restrição). Esta critica será oportunamente analisada adiante.
}

${ }^{157} 543$ U.S. 551 - 2005 
menores de 18 anos à época do cometimento do crime, o voto vencedor apontou, entre outros fundamentos, que inúmeras nações democráticas e desenvolvidas, que compartilhavam valores com os Estados Unidos, haviam banido a aplicação de pena capital a menores de idade.

Scalia $^{158}$ se insurgiu aduzindo que a Corte estava a fazer o uso seletivo e irracional de fontes estrangeiras, pois a pesquisa sempre se referia a Tribunais Constitucionais e Internacionais que apresentavam opiniões que iam ao encontro da posição vencedora, na hipótese, decisões e legislação estrangeiras que vetavam a aplicação de pena de morte a menores.

Desenvolvendo-se o raciocínio de Scalia, tem-se que a Suprema Corte Americana, tendo decidido recorrer a precedentes estrangeiros no caso em comento, deveria também analisar a legislação e a jurisprudência de outros países que adotavam a pena de morte a menores como, por exemplo, o Irã. A pergunta que se põe, então, seria qual a relação entre os Estados Unidos e o Irã? Seria necessário demonstrar a utilidade desta comparação, evidenciando-se os elementos que poderiam conectar os dois ordenamentos no caso da imposição da pena capital a menores.

Num caso tão contrastante, como na comparação entre Estados Unidos e Irã, a pergunta que se põe é: seria realmente necessário que a Corte mostrasse os dois "lados da moeda", ainda que os países que apoiassem a aplicação de pena capital a menores fossem evidentemente tão diferentes dos Estados Unidos em diversos aspectos? Se a comparação fosse feita, quais seriam os elementos que ligariam, de alguma maneira, os Estados Unidos e o Irã?

Indubitavelmente, no caso da pena de morte a menores, houve seletividade de precedentes. Seria isto um óbice ao uso de precedentes estrangeiros? Obviamente não, pois a seletividade se deu, inegavelmente, em virtude de uma escolha anterior, na qual se teve por bem olhar como outros países semelhantes, que compartilham os valores com os Estados Unidos e possuem culturas similares, tratam o assunto.

Este exemplo demonstra exatamente como o binômio consensoseletividade é um falso problema. Na realidade, uma discussão que queira ser produtiva sobre

\footnotetext{
${ }^{158}$ Ibidem
} 
o tema em análise não deve ser feita com base na contagem de países pró ou contra determinada posição ou focando-se exclusivamente na problemática da seletividade, mas, sim, em se indagando quando o consenso pode ser relevante e de que forma pode ser realizada a seleção de precedentes.

Demonstrado, desde logo, serem o consenso e a seletividade, respectivamente, uma resposta inadequada e um falso problema, qual o impacto deles sobre o uso de precedentes estrangeiros?

No que concerne ao consenso, sua importância não deve ser desconsiderada, mas ele também não deve ser colocado como critério central para a utilização de precedentes estrangeiros. Em verdade, o consenso sobre determinada questão deve ser visto como um indício e como elemento que aumenta a força de um dado argumento. No entanto, jamais deve ser encarado como algo que impeça a conversa constitucional, haja vista que o uso de material alienígena pode ocorrer também para autoconhecimento, para a diferenciação e não apenas para se aderir a uma posição majoritária.

Em suma, o consenso mundial, por si só, não pode ser visto como elemento suficiente a legitimar a aplicação de um ou de vários precedentes estrangeiros, uma vez que aqui se defende o uso de precedentes como elemento argumentativo-persuasivo. O consenso mundial, no modo dialógico, tem o papel de impor ao intérprete da norma constitucional um maior ônus argumentativo para afastar a posição majoritária, mas não o poder de impedir o seu afastamento ou, contrariamente, impor sua aplicação.

Sob esta perspectiva, a decisão que vai contra um consenso mundial poderia, aqui, ser equiparada a uma decisão constitucional contramajoritária, isto é, que afasta uma lei legítima do ponto de vista formal, mas inconstitucional por ofender valores do constitucionalismo. E de todos é sabido que quando uma Suprema Corte ou um Tribunal Constitucional, por algum motivo, decide decretar a inconstitucionalidade de alguma legislação que foi democraticamente promulgada para preservar os direitos de uma minoria ou valores que sustentam seu o próprio constitucionalismo, seu ônus argumentativo, a justificativa para afastar a "vontade do povo" deve ser muito clara e bem fundamentada. Desta forma, quando uma Corte Constitucional for analisar um caso difícil, em que é possível aferir um consenso ou uma tendência mundial, e caso entenda ela que o ordenamento jurídico sob 
análise demanda uma resposta distinta daquela alcançada pelos demais, ela terá que explicita e cuidadosamente explicar porque se afasta das premissas que alicerçam o consenso.

Desta forma, os argumentos que fundamentam a posição majoritária e o próprio consenso teriam papel de elemento indicativo, de uma direção a ser seguida, de uma evolução cultural e social a caminho, mas jamais seria algo obrigatório, ou simplesmente aplicável por se consubstanciar em mero consenso.

Neste diapasão, o consenso pode servir de reforço para a decisão doméstica a ser tomada ou, em caso de rejeição, uma forma de comparação que permite delinear melhor os conceitos fundantes de um povo e os dogmas jurídicos de seu ordenamento.

Por outro lado, a seletividade de cortes estrangeiras não pode ser vista como um óbice à utilização de precedentes estrangeiros, porque, desde que justificada e coerente, o uso de determinada decisão alienígena no controle de constitucionalidade não se torna ilegítimo em virtude da seleção, mas, sim, em decorrência de uma escolha não justificada e descontextualizada.

Como será demonstrado adiante, nos casos em que a comparação ocorre na ausência de consenso ou mesmo em situações que a comparação é realizada com um ou poucos precedentes, a seletividade se dará de várias maneiras, mas de forma alguma ela tem o condão de deslegitimar o uso de precedentes estrangeiros.

Ademais, como já afirmado, os elementos de conexão entre o caso doméstico e o estrangeiro podem aparecer nas situações mais inesperadas. Tende-se a pensar que a seleção de precedentes e material estrangeiro terá sempre por baliza as semelhanças conjunturais entre as nações, isto é, pensando-se nas possibilidades de comparação num plano genérico e abstrato, países similares, como um todo, seriam a primeira opção comparativa.

No entanto, a comparação não decorre apenas de similaridades globais evidentes, mas, muitas às vezes, ocorre em função de uma semelhança pontual. Como já dito, países muito distintos, podem em determinadas áreas renderem comparações frutíferas, como já mencionado exemplo de possibilidade de comparação entre Irlanda e Índia na seara das relações entre democracia e religião. 
Ao mesmo tempo países que parecem, em uma rápida análise, muito próximos, podem se distanciar bastante em pontos específicos, como é o caso de Inglaterra e Estados Unidos, que embora compartilhem valores e sejam culturalmente próximos, apresentam diferenças consideráveis em algumas estruturas do Estado, que podem ser resumidas nos seguintes contrastes: ausência de uma constituição escrita e rígida/existência de uma constituição escrita e rígida, monarquia/república e parlamentarismo/presidencialismo. Portanto, a depender do que está sendo julgado, mesmo a evidente proximidade entre Inglaterra e Estados Unidos pode não ser suficiente para realizar uma comparação.

$\mathrm{Na}$ verdade, o que se quer demonstrar com estes exemplos em que países tão distintos podem ser comparados em pontos específicos e que países tão similares podem não ser comparáveis em determinadas situações é justamente que o consenso e a seletividade ocorrem em função do tema que está sob julgamento, não se podendo, $a$ priori, afirmar que o consenso sempre importa, nem se dizer que a comparação deve se reduzir a um grupo de países homogêneos (democracias ocidentais, por exemplo).

Portanto, é preciso evitar que a armadilha do consenso impeça o uso de direito estrangeiro e que a seletividade seja vista como um problema que deslegitime a utilização de precedentes estrangeiros. Na realidade, o problema decorre da ausência de justificação ao se usar o consenso ou da não fundamentação de determinada seleção de precedentes estrangeiros, situações estas que, sim, podem levar a decisões ilegítimas.

Desta feita, o modo dialógico, como aqui proposto, por um lado, defere importância ao consenso mundial, ao vê-lo como um argumento a ser enfrentado, mas não o toma como critério único e central apto a controlar e legitimar a utilização de precedentes estrangeiros, haja vista que o recurso ao material alienígena apenas em razão de uma posição majoritária em pouco colaboraria com um verdadeiro intercâmbio constitucional. Por outro lado, a seletividade de precedentes, desde que feita de maneira criteriosa e justificada, não é um problema que vede o diálogo constitucional, ou seja, o uso legítimo do direito estrangeiro não requer a existência de consenso ou mesmo que seja feita uma análise sobre a posição de todas as Supremas Cortes sobre determinado tema. 
Logo, a comparação com outras jurisdições legitimar-se-á pelo modo através do qual é feita a comparação, isto é, pelos motivos pelos quais se recorre ao material estrangeiro, bem como pelo propósito e finalidade da comparação.

\subsection{AS ÁREAS EM QUE SE PODE UTILIZAR O PRECEDENTE ESTRANGEIRO: APENAS O USO PRAGMÁTICO OU TAMBÉM NAS QUESTÕES JURÍDICO-MORAIS?}

Muitos autores ${ }^{159}$ defendem que a utilização de precedentes estrangeiros apenas poderia acontecer quando tivesse por fim analisar as consequências de determinada decisão, isto é, quando o uso se desse no modelo pragmático, empírico ou avaliativo.

Um dos exemplos mais citados acerca do uso pragmático é o caso Miranda v. State of Arizona ${ }^{160}$, no qual a Suprema Corte Americana analisava se as declarações e as confissões obtidas pela polícia sem a participação de um advogado de defesa na fase do inquérito policial seriam admissíveis no subsequente processo criminal. De um lado era invocada a vedação à autoincriminação $\left(15^{\mathrm{a}}\right.$ emenda) e o direito à assistência de um advogado (sexta emenda) e, de outro, asseverava-se que estes direitos dificultariam a aplicação da lei penal e aumentariam a criminalidade.

Em decisão apertada a Corte Americana decidiu que a confissão de um crime ou outras declarações do investigado não seriam admissíveis ao menos que fosse comprovado que o acusado foi informado de seu direito de não se incriminar (direito ao silêncio) e de ter a assistência de um advogado ${ }^{161}$.

\footnotetext{
${ }^{159}$ Por exemplo: CALABRESI, Steven and ZIMDAHL, Stephanie Dotson. The Supreme Court and Foreign Sources of Law..., p. 743; ZEHNDER, Jacob J. Constitutional Comparativism: The Emerging Risk of Comparative Law as a Constitutional Tiebreaker. In: Valparaiso University Law Review, vol. 41, n. 4, 2007 , pp.. 1739-1788; LEVINSON, Sanford V. Looking Abroad When Interpreting the U.S. Constitution: Some Reflections [Symposium: Globalization and the Judiciary]. In: 39 Texas International Law Journal, 2004, p. 353.

160384 U.S. $436-1966$

161 “A pessoa em custódia deve, antes do interrogatório, ser explicitamente informada de que ela tem o direito de permanecer em silêncio e que tudo o que ela disser poder ser usado contra ela no processo criminal; ela deve ser claramente informada que ela tem o direito de ser assistida por um advogado e tê-lo com ela durante o interrogatório, e que, se for um hipossuficiente, um advogado será nomeado para representá-la".
}

$(\ldots)$ 
Nesta oportunidade, para fundamentar sua decisão, entre vários argumentos, a maioria recorreu ao direito estrangeiro, asseverando que Inglaterra, Escócia, Índia e Ceilão conferiam aos seus acusados o direito de serem informados sobre seus direitos ao silêncio e à assistência de um advogado e que tais direitos não implicavam em maior dificuldade de aplicação do direito penal, nem em aumento nos índices de criminalidade.

Segundo estes autores, o modelo pragmático teria a vantagem de se valer da experiência de outros povos sem, no entanto, contaminar-se com a cultura estrangeira ou afrontar os valores domésticos. É evidente que a intenção daqueles que se posicionam pelo uso do direito estrangeiro apenas para fins pragmáticos é evitar os demais modos de uso, afastando-se da polêmica e partindo da premissa de que o uso pragmático seria asséptico e estaria totalmente desconectado da moral.

Todavia, embora o uso meramente pragmático possa parecer, numa primeira vista, algo simples, sem maiores objeções, pois significaria apenas aferir se a legislação ou a decisão " $\mathrm{X}$ " teriam em dada comunidade "Y" o efeito "Z" ou "W", estas análises não são tão simples como parecem.

Inicialmente é preciso lembrar que aspectos culturais, sociais e econômicos afetam o Direito e a capacidade das decisões judiciais de serem aceitas e efetivas. Embora estas condições externas ao Direito não impeçam a análise empírica de decisões judiciais em outros ordenamentos, elas, sem dúvidas, influenciam o resultado decorrente de dada legislação ou decisão judicial em determinada comunidade, ou seja, mesmo a análise pragmática, para ser feita adequadamente, demanda a compreensão de elementos que fogem da seara unicamente jurídica.

Assim, por exemplo, analisar se a pena de morte é forma de sanção criminal que exerce forte impacto sobre a redução dos índices de criminalidade é algo difícil de aferir unicamente pelo viés jurídico. Basta comparar os índices de criminalidade em

\footnotetext{
"Se o indivíduo indicar, de qualquer maneira, a qualquer momento ante ou depois do interrogatório, que ele deseja ficar em silêncio, o interrogatório deve ser finalizado... Se o individuo aduz que ele quer um advogado, o interrogatório deve ficar suspenso até que o defensor esteja presente. Neste momento, o indivíduo deve ter a oportunidade de falar a sós com o advogado e tê-lo presente no em qualquer interrogatório subsequente".
} 
países como Estados Unidos e Noruega ${ }^{162}$, ambas nações ocidentais democráticas com valores comuns. Contrariamente ao senso comum de que penas mais severas inibiriam o cometimento de homicídios, a Noruega, que apresenta legislação mais liberal no tocante à pena de morte, apresenta taxas de criminalidade consideravelmente mais baixas do que os Estados Unidos. De onde, então, viria a significativa diferença nas mencionadas taxas de violência? Muito provavelmente de fatores culturais, da efetividade da atividade policial, da facilidade para se comprar ou não armas de fogo, todos estes fatores externos ao Direito e que envolvem a análise pragmático-jurídica.

Como já dito, o exemplo trazido à baila não tem por fim criar objeções ao uso de direito estrangeiro ante a dificuldade que análises pragmáticas podem conter $^{163}$, mas apenas demonstrar que mesmo em situações em que o uso de material alienígena tem por objetivo uma análise puramente empírica, ele não estará totalmente isento de elementos culturais, morais, políticos e econômicos.

Em segundo lugar, considerando-se que a utilização de precedentes estrangeiros aqui defendida baseia-se no modo dialógico, a interlocução constitucional restaria bastante empobrecida no caso de utilização unicamente consequencialista, descartando toda uma gama de possibilidade de interações constitucionais que poderiam ser proveitosas.

Ademais, como explica Richard Markovits ${ }^{164}$, a restrição ao uso de material estrangeiro em questões puramente pragmáticas sob a alegação de que qualquer polêmica moral deva ser respondida com base apenas em um consenso comunitário doméstico parte de uma premissa individualista que pode se confrontar com as premissas jurídico-morais de um mesmo ordenamento jurídico. Em outras palavras, conforme assevera o professor norte-

\footnotetext{
162 De acordo com o Escritório das Nações Unidas sobre Drogas e Crime (UNODC), a taxa de homicídios dolosos, nos E.U.A, onde a pena de morte é permitida, é de 4,2 a cada 100 mil habitantes, enquanto na Noruega, onde não há pena capital, é 0,6 a cada 100 mil habitantes (disponível em http://www.unodc.org/unodc/en/dataand-analysis/homicide.html).

${ }^{163}$ Ran Hirschl (Comparative Constitutional Law...) e Christopher Whytock (op. cit.) apontam que este problema pode ser resolvido usando-se as ciências sociais, o que parece ser a lógica de se recorrer a peritos quando o juiz está analisando questões econômicas complexas ou causas que envolvem erro médico.

164 MARKOVITS, Richard S. Learning from the Foreigners: A Response to Justice Scalia's and Professor Levinson's Professional Moral Parochialism [Symposium: Globalization and the Judiciary]. In: 39 Texas International Law Journal, 2004, p. 367.
} 
americano, as questões jurídico-morais de dado ordenamento devem sempre ser analisadas à luz de seus valores básicos e fundantes derivados do pacto social inicial. Desta forma, uma abordagem puramente individualista sobre questões concretas pode ser inconsistente com as premissas adotadas por um ordenamento jurídico, sendo que, no caso de colisão, as segundas, abstratas e fundantes, devem prevalecer sobre a primeira, concreta e específica.

Como exemplo, ele cita o caso da aplicação da pena de morte a menores e da proibição de relações homossexuais. Em ambos os casos, uma pesquisa popular, ou até um referendo, poderia indicar que tais proposições são aquelas que refletem a posição individual-majoritária sobre tais temas em dada comunidade. Todavia, tais posições podem estar em confronto com valores fundantes desta mesma sociedade, como a liberdade e a igualdade.

Em casos como estes, em que não estão envolvidas questões pragmáticas, mas valores jurídicos, o uso do precedente estrangeiro pode vir a ser um elemento que oferece um grande aprendizado, especialmente quando a comparação é feita entre países que compartilham os mesmos valores básicos. Com efeito, o uso de direito estrangeiro pode ser útil à medida que expande o horizonte do julgador e traz para a discussão novas possibilidades de construção de linhas argumentativas que articulam valores de maneira diferente, em especial no que se refere aos compromissos jurídicos-morais mais amplos em oposição aos mais concretos ${ }^{165}$.

Desta feita, o uso de precedentes estrangeiros não deve se restringir apenas a situações nas quais o Tribunal busque aferir o resultado de determinada decisão, mas também em áreas que envolvam questões normativo-morais, como nos casos difíceis e nas questões contramajoritárias. Saliente-se, mais uma vez, que a utilização de precedentes estrangeiros pode ser tanto positiva como negativa, mas, em ambos os casos, desde que justificada, tem a salutar função de ser instrumento que traz para a discussão um enriquecimento argumentativo apto a melhorar o processo de tomada de decisão.

Logo, a restrição à utilização de precedentes estrangeiros apenas nos casos em que se busca aferir a consequências de determinada decisão, além de carecer de fundamentos, pois não é possível isolar apenas a causa jurídica de determinado resultado,

\footnotetext{
${ }^{165}$ Ibidem (MARKOVITS), p. 375.
} 
impossibilita que um repertório infindável de decisões e ideias auxiliem o processo de controle de constitucionalidade, ainda que o julgamento contenha questões que possam envolver a moral ou valores morais constitucionalizados.

\subsection{O USO DE PRECEDENTES ESTRANGEIROS PAUTADOS PELO CRITÉRIO DA PRIMAZIA DO PRINCÍPIO HUMANO MAIS BENÉFICO E PELA EXPANSÃO DOS DIREITOS HUMANOS}

André Ramos Tavares ${ }^{166}$, Cindy Buys ${ }^{167}$ e, especialmente, por Guilherme Amorim Campos da Silva ${ }^{168}$, defendem que a utilização de precedentes estrangeiros deve ocorrer sempre que resulte na ampliação da eficácia e do alcance dos direitos fundamentais ${ }^{169}$.

Campos da Silva ${ }^{170}$ aponta, entre vários critérios para a utilização de precedentes estrangeiros, dois que interessam ao presente trabalho: a primazia do princípio mais benéfico e seu consectário, a primazia do precedente estrangeiro mais benéfico.

Em relação ao primeiro aduz que este é a

Obrigação de dispensar a interpretação mais benéfica e consentânea com a unicidade e indivisibilidade dos direitos humanos fundamentais

$(\ldots)$

O cânone de interpretação 'primazia do princípio mais benéfico' atua, ainda, no sentido de emprestar necessária coerência ao uso de precedentes estrangeiros pelo Supremo Tribunal Federal, na medida em que afasta ou rechaca o uso de precedentes que criam restricões não autorizadas ou desarrazoadas a direito humanos fundamentais.

\section{(...)}

\footnotetext{
${ }^{166}$ Modelos de uso da jurisprudência...

${ }^{167}$ BUYS, Cindy G. Burying Our Constitution in the Sand?: Evaluating the Ostrich Response to the Use of International and Foreign Law in U.S. Constitutional Interpretation. In: Bepress Legal Series, Paper 1094, 2006.

${ }^{168}$ O uso de precedente estrangeiro pela Justiça Constitucional...

${ }^{169}$ Idem, ibidem, p. 306.

${ }^{170}$ Idem, ibidem, pp.. 317-321.
} 
Em relação aos precedentes estrangeiros, o presente 'critério de eleição e interpretação' reveste-se de sensibilidade e importâncias 'jurídicas', na medida em que a 'utilidade' de seu uso está presente na necessidade de se harmonizar as clausulas constitucionais de direitos humanos fundamentais e projetá-los na realidade de maneira correta e adequada [e preservar sua eficácia irradiante], atendendo-se os pressupostos normativos sistêmicos

(...)

O critério ora eleito para a invocação de preceito constitucional estrangeiro, portanto, busca estabelecer como 'axioma' a obrigatoriedade normativa de se identificar, entre os princípios constitucionalizados e positivados no ordenamento jurídico nacional e supranacional, e daquele decorrente da atuação dos Tribunais Constitucionais dos países integrantes desse Sistema Internacional, $\underline{\mathbf{0}}$ princípio mais benéfico à plena protecão e concretizacão de cláusula de direitos humanos fundamentais

(...)

Aqui a pluralidade de decisões estrangeiras de fontes normativas elegíveis segundo os critérios delimitados neste trabalho, é condição de admissibilidade e validade do precedente estrangeiro pelo Supremo Tribunal Federal.

(grifou-se)

Adiante $^{171}$, ao tratar da primazia do precedente estrangeiro mais benéfico, que se consubstanciaria na "identificação de possibilidade normativa de uma unificação ético-valorativa", Campos da Silva filia-se ao naturalismo, sem desconsiderar o direito positivo, acentuando a importância da interpretação para aplicação do direito nas situações concretas. Desta forma, para ele, a utilização do precedente estrangeiro mais benéfico seria decorrência lógica do princípio da interpretação mais benéfica. Desta forma ${ }^{172}$ :

\footnotetext{
${ }^{171}$ Idem, ibidem, p. 322 e seguintes.

${ }^{172}$ Idem, ibidem, p. 323.
} 
O Juiz constitucional, ao tratar do precedente estrangeiro 'deverá' considerar sua pertinência e razoabilidade, além de sua proporcionalidade como solucão mais efetiva ao caso sob exame, a 'verificação' e sua precedência sobre outros 'possíveis' precedentes por conta de se constituir, dentre um conjunto de decisões, 'naquele' que veicula um entendimento 'mais benéfico' à proteção de direitos humanos fundamentais.

(...)

O desafio de sua identificação consiste na análise de sua precedência no contexto da decisão, ou seja, no âmbito do ordenamento jurídico em que proferida, sua pertencialidade e acerto perante o SIPDH, recorrência de seus pressupostos em um conjunto demonstrativo do acerto de suas premissas e conclusões

(...)

Assim o desenvolvimento de uma jurisprudência baseada em precedentes estrangeiros tem o condão de possibilitar a identificação, a partir de realidade intercambiáveis, de um conjunto de conteúdos jurídicos materiais constitucionais não escritos, mas explicitados pela atividade racionalista de uma justificação constante do Direito perante as exigências da vida social e de um ordenamento jurídico nacional-supranacional. (grifou-se)

Em suma, afere-se das passagens acima transcritas que o uso de precedentes estrangeiros com base no critério da interpretação expansiva dos direitos humanos emprestará coerência ao uso de precedentes estrangeiros, que irá harmonizar as cláusulas constitucionais de direitos humanos fundamentais, preservando sua eficácia irradiante, ao mesmo tempo em que a pluralidade de precedentes é condição de admissibilidade e validade do uso precedente estrangeiro. Por fim, aduz que o precedente estrangeiro deverá ser utilizado com base na sua razoabilidade, proporcionalidade e pertencialidade, de maneira a permitir a identificação de conteúdos jurídicos constitucionais não escritos.

Inegável a dificuldade de compreender, analisar e conciliar as ideia defendidas por Campos da Silva. Mas mais do que isso, o critério apresentado apresenta 
grandes dificuldades de aplicação e não maiores detalhamentos acerca de como descobrir qual o precedente mais favorável.

Primeiramente esclareça-se que a noção de prevalência do princípio mais benéfico ou da interpretação expansiva dos direitos humanos (que não são objeto deste trabalho), são assuntos bastante controversos e que ainda não encontraram aceitação generalizada ou uma metodologia que permita aferir qual o princípio mais benéfico ou que trará maior expansão aos direitos humanos. De qualquer forma, o que importa, neste momento, é apenas frisar a grande dificuldade acerca do significado do que seja princípio mais benéfico ou interpretação ampliativa dos direitos humanos.

Em segundo lugar, uma visão extremamente valorativa do Direito, centrada fortemente na criação judicial e que busca uma ampla convergência e aproximação dos ordenamentos jurídicos, desconsidera tanto o aspecto cultural do direito, como as fundações democráticas do constitucionalismo, como já tratado no capítulo 1 deste trabalho.

Em terceiro lugar e mais importante, não se pode olvidar que o próprio autor elencou a primazia do precedente estrangeiro mais benéfico como critério, ou seja, a decisão estrangeira que cristalizar uma posição em que há princípio mais benéfico deve ser seguida. Contudo, não apontou como encontrar ou constatar qual o precedente estrangeiro mais benéfico frente a pluralidade de precedentes, a qual é a condição de admissibilidade e validade do uso de material alienígena.

Em outras palavras, a pluralidade é requisito para o uso, mas não foi apontado qualquer critério para a seleção de precedentes. $\mathrm{Na}$ realidade, ao menos da maneira posta pelo autor, expandir os direitos humanos ou adotar o princípio mais benéfico é uma finalidade e não um critério.

Mesmo que se queira enxergar o princípio mais benéfico ou a interpretação expansiva dos direitos humanos como critério a pergunta que se põe é a seguinte: como pode o juiz constitucional identificar o precedente estrangeiro mais benéfico sem antes decidir qual é o princípio mais benéfico no âmbito interno? Posto de outra maneira: se o precedente estrangeiro a ser adotado deve ser aquele que amplie um direito humano, qual o papel, neste caso, do direito doméstico? 
Apenas duas possibilidades surgem adotando-se esta perspectiva: ou a Corte Constitucional afere no plano interno qual o princípio mais benéfico e, posteriormente, procura, no exterior, decisões que apoiam sua conclusão, procedendo a uso meramente decorativo do precedente estrangeiro, ou a Corte, frente ao caso concreto, adota o precedente estrangeiro que entende melhor ampliar os direitos humanos e depois tenta, de alguma forma, conciliá-lo com o direito interno.

Por fim, vale ressaltar que a dinâmica fortemente valorativa adotada por Campos da Silva, baseada em conteúdos constitucionais não escritos em vez de buscar o diálogo constitucional, como aqui defendido, abre espaço exacerbado para o decisionismo judicial, ainda mais com a indicação de que os precedentes judiciais devem ser aferidos com base na sua proporcionalidade, razoabilidade e pertencialidade, critérios estes extremamente vagos e não detalhados pelo autor.

Em conclusão, esta visão centrada num forte subjetivismo judicial e em valores etéreos e excessivamente abstratos ignora a frutífera interlocução constitucional que pode surgir mesmo em situações em que não há convergência alguma, bem como não promove o autoconhecimento na medida em que se baseia apenas naquilo em que a humanidade pode ter em comum, desconsiderando a singularidade de cada um. Outrossim, vale frisar que mesmo que acolha as sugestões ofertadas por Campos da Silva, os subcritérios por ele apontados não foram explicados e não parecem de fácil articulação.

Desta feita, o princípio da primazia do precedente mais benéfico não pode ser considerado um critério adequado e racional para a utilização de precedentes estrangeiros.

\subsection{OS CRITÉRIOS PARA REALIZAÇÃO DA COMPARAÇÃO: OS ELEMENTOS DE CONEXÃO ENTRE O CASO DOMÉSTICO E OS PRECEDENTES ESTRANGEIROS.}

Visto que é desnecessária a autorização explícita da constituição para que a jurisdição constitucional recorra ao uso de material estrangeiro no controle de constitucionalidade; que o ponto de partida é sempre o texto constitucional sob análise; que o consenso mundial sobre determinado tema, por si só, não é critério a justificar o uso de precedentes estrangeiros; que a seletividade de fontes não é um problema, desde que 
justificada; que a utilização de material alienígena pode ocorrer tanto no campo empírico, como no jurídico-moral; e que o princípio da primazia do precedente mais benéfico não é um critério válido, passa-se, agora, a estabelecer alguns critérios que possam balizar o uso de precedentes estrangeiros pela jurisdição constitucional.

Primeiramente cumpre salientar que os critérios que aqui serão delineados não se consubstanciam em uma fórmula matemática, na qual apenas são inseridos os algarismos da equação, que, por sua vez, apontaria um resultado de forma clara e inquestionável. Trata-se, na realidade, de critérios que têm por fim nortear o uso de precedentes estrangeiros, isto é, servirem de guia para seu uso racional, mas sem ter qualquer ambição em solucionar de maneira exata um problema altamente complexo, que se insere dentro da polêmica seara da interpretação e da argumentação jurídica.

Esclarecido o intuito do presente item, pode-se, então, indicar quais são as circunstâncias que permitem o uso de material estrangeiro pela jurisdição constitucional no controle de constitucionalidade. Para tanto, optou-se em ver os possíveis critérios não como requisitos objetivos e taxativos, mas como elos que permitem a ligação entre o doméstico e o externo de maneira racional.

Considerando-se que a palavra critério poderia soar como algo mais rígido, que não permitisse muitas variações e combinações, isto é, como uma regra que permita, ou não, a utilização de precedentes estrangeiros de forma direta sem abarcar todas as nuances que podem surgir por meio da interlocução constitucional, optou-se por usar outra nomenclatura para se referir aos parâmetros para utilização de julgados alienígenas pela jurisdição constitucional.

Assim, em vez da palavra critério, será adotado o termo "elementos de conexão", ou seja, os elementos que, quando presentes, possibilitam a interlocução constitucional, tornando-a plausível, útil e compatível com os tradicionais métodos de interpretação constitucional.

Note-se que o termo aqui usado, "elementos de conexão", embora possa, eventualmente, ter alguma similaridade com o mesmo termo usado no campo do direito internacional privado, com ele não se confunde. Este último conceito trata de situações em que há conflito de leis no espaço e tenta, para a solução do mesmo, estabelecer 
regras para se descobrir qual a legislação aplicável ${ }^{173}$. Diferentemente, os elementos de conexão para fins de uso de precedentes estrangeiros não são regras estanques, mas situações que quando constadas e demonstradas permitem as mais diversas formas de interação. Também não há conflito, mas apenas interação, seja ela positiva ou negativa. Por fim, a regra ou princípio oriundo de precedente estrangeiro jamais poderá ser aplicada na seara doméstica diretamente, como ocorre na área do direito internacional privado, sendo, como já repetido inúmeras vezes, apenas um instrumento auxiliar e útil para se alcançar decisões melhores no âmbito interno.

Importante também ressaltar que não é possível estabelecer estes elementos de conexão a priori, como se fossem critérios gerais e abstratos aplicáveis a todos os casos (ideia ou finalidade do direito internacional privado). Pelo contrário, os elementos de conexão são múltiplos, cumuláveis e somente identificáveis frente a um caso concreto ${ }^{174}$, dentro de determinado contexto doméstico. É justamente a partir do cotejo entre o caso em discussão, o ordenamento doméstico e os mais diversos precedentes estrangeiros que surgem os elementos de conexão. Isto não quer dizer que não se possa descrevê-los e sistematizá-los, como adiante será feito, mas que a sua aplicabilidade ao caso concreto dependerá de variáveis apenas identificáveis em cada hipótese.

Também é preciso esclarecer que o elemento de conexão não necessariamente surge apenas quando há identificação ou semelhança entre o texto constitucional escrito e a constituição estrangeira. Em outras palavras, a coincidência ou similaridade de textos constitucionais não é condição sine qua non para se utilizar o precedente estrangeiro, pois tal premissa desconsidera a importância do contexto, tanto o jurídico, como o social e político. Isto porque, em primeiro lugar, a norma descontextualizada em nada colabora com a comparação, pois seu significado advém sempre de um contexto; em segundo lugar, comparar apenas semanticamente dois textos, muitas vezes oriundos de línguas distintas, seria uma tarefa nada ou quase nada produtiva; por fim, analisar um único

\footnotetext{
${ }^{173}$ DOLINGER, Jacob. Direito Internacional Privado - Parte Geral. 55 ${ }^{\mathrm{a}}$ Ed. Rio de Janeiro: Renovar, 1997, p. 260.

174 Neste sentido: DE VERGOTTINI, Giuseppe. Más allá del diálogo entre tribunales - Comparación y relación entre jurisdicciones. $1^{\text {a }}$ Ed. Pamplona, Espanha: Thompson Reuters, 2010 p. 210.
} 
dispositivo em cotejo com outro estrangeiro desconsideraria suas relações com os respectivos ordenamentos jurídicos que lhes deram origem.

Portanto, partir simples e unicamente do texto constitucional e dizer que só é possível a comparação nos casos em que haja semelhança não é, ao ver deste trabalho, uma objeção válida, pois além de se desconsiderar o papel do contexto no significado da norma, comparações entre institutos jurídicos inteiros restariam impedidas de serem realizadas, sem considerar que, inúmeras vezes, os textos constitucionais em comparação são bastante diferentes, mas a situação em julgamento é a mesma. Logo, da mesma forma que texto e norma são consideradas coisas diferentes, os textos constitucionais, embora possam ser divergentes na sua literalidade, podem apresentar conflitos de normas idênticos ou similares.

Pois bem, postas estas considerações e com base no que foi estudado até agora, constatou-se que os elementos mais comuns de conexão são: a relação histórica entre países, a influência estrangeira na elaboração da constituição e a importação de legislação, questões empíricas, o compartilhamento de valores comuns, similaridades ou diferenças sociais e culturais entre as nações.

\subsubsection{A relação histórica entre países}

No tocante ao primeiro elemento, qual seja a relação histórica entre países ${ }^{175}$, ele se desdobra em três possibilidades: uma primeira, que pode se denominar de relação histórica direta, que ocorre entre ex-colônia e a antiga metrópole, como na relação entre Estados-Unidos e Inglaterra; uma segunda, que seria indireta, quando duas nações possuem um ex-colonizador comum, como no caso da relação entre Colômbia e Argentina em referência à Espanha; em terceiro lugar, uma genérica, quando o contexto histórico seja mais amplo, envolvendo questões históricas comuns ou semelhantes, como ocorre na América

\footnotetext{
${ }^{175}$ De acordo com Sujit Choudry, este modo de utilização de precedentes estrangeiros é aplicável a constituições que, por motivos históricos, apresentam complexas relações genealógicas, as quais oferecem justificação suficiente para a importação de abrangentes teorias e doutrinas constitucionais. Estas constituições são fortemente ligadas como se fossem pais e filho ou como irmãos por terem emergido de um mesmo tronco familiar. (In Globalization in seach ..., p. 838). No presente tópico, além das possibilidades apresentadas por este autor, incluir-se-á as comparações entre países que, embora possam não ter relação direta de parentesco, tem histórico similares.
} 
Latina, que apresenta um processo de colonização e dominação similar em todo o continente, ainda que existam peculiaridades na história de cada nação.

A presença dessas relações de "parentesco" entre os estados, embora não possa ser considerada, por si só, suficiente para permitir, diretamente, a utilização de precedentes estrangeiros, é um elemento que muito facilita o trabalho de justificação do magistrado, pois as raízes históricas comuns podem trazer uma série de vantagens ou facilidades, como por exemplo, o compartilhamento de uma mesma língua ou a familiaridade com o sistema jurídico e político do estado "parente". Isto é frequente principalmente no que tange as duas primeiras possibilidades, a relação histórica direta e a indireta.

Poderia se questionar aqui, ainda, se o pertencimento a uma das grandes famílias do direito ocidental, a romano-germânica ou a anglo-saxônica, seria um elemento de conexão suficiente para a utilização de precedentes estrangeiros. Ao que parece não. Embora possa ser visto um como um elemento indiciário que propiciasse a interlocução constitucional, o mero pertencimento a determinada família do direito ocidental é insuficiente, por si só, para estabelecer uma comparação produtiva.

Primeiramente porque a divisão entre "civil law" e "common law" é muito genérica e o nível de abstração para essa classificação é tão alto que não há como se fazer referência a elementos concretos de conexão. Em segundo lugar, a principal diferença entre os dois sistemas reside na forma como se dá a produção de normas jurídicas (legislação versus jurisprudência), o que não influencia, ao menos diretamente, a jurisdição constitucional, que lida com questões mais relacionadas à contenção do poder do Estado e conflito entre direitos fundamentais. Em terceiro lugar e por último, a distinção entre os dois grupos está cada vez menos clara, ante as influências recíprocas entre os países, havendo uma aproximação dos sistemas. Assim, a mera filiação a determinada família jurídica é elemento bastante fraco, inapto a gerar diálogo que se paute por uma argumentação coerente e consistente.

Observe, ainda, que este elemento de conexão, denominado de "histórico" não se consubstancia em uma "via de mão única", mas, ao contrário, numa "via de mão dupla”, isto é, não apenas os países outrora colonizados podem aprender com a ex- 
metrópole, como esta também pode enriquecer suas discussões com as ideias de suas excolônias $^{176}$.

Um exemplo sobre o uso do elemento histórico como forma de justificar a utilização de precedente estrangeiro ocorreu no caso $R$. v. Van der Peet ${ }^{177}$, julgado pela Suprema Corte Canadense, no qual a questão posta era se os peixes caçados pelos índios canadenses podiam ser vendidos comercialmente. No caso concreto, um indígena foi multado e proibido de vender os dez salmões que havia sido pescado.

A celeuma constitucional em discussão era a amplitude dos direitos indígenas dos povos nativos canadenses. $\mathrm{O}$ assunto era tratado de forma genérica e aberta pela constituição canadense, que apenas previa, em sua seção 35, a existência de direitos dos indígenas, mas não apresentava qualquer outro dispositivo que os elencasse ou os conceituasse. Não havia, portanto, dispositivo normativo-constitucional para se identificar e definir quais e como eram estes direitos. Enfim, a Corte tinha de decidir se a lei que impedia a venda comercial de peixes pelos indígenas violava seus direitos constitucionais.

Entre vários argumentos, a Corte Canadense recorreu ao elemento histórico para se utilizar da jurisprudência americana e australiana. Esclareceu que estes países eram todos ex-colônias britânicas e que seus territórios eram habitados por aborígenes antes da chegada do colonizador europeu, situação esta que deu origem, no império britânico, ao desenvolvimento dos direitos indígenas. Repare que, nesta oportunidade, o Tribunal aproveitou-se tanto da relação de irmandade entre Canadá, Estados Unidos e Austrália, como da ligação ancestral comum referente ao Império Britânico.

\footnotetext{
${ }^{176}$ Sobre este assunto vale transcrever parte do voto do juiz e professor de direito Guido Calabresi, no julgamento do caso United States v. Then (n. 1359, Docket 94-1485, June 05, 1995 - US 2nd Circuit): "Anteriormente, os Estados Unidos tinham o monopólio sobre o controle de constitucionalidade e se uma doutrina ou abordagem não tivesse sido feita aqui na América, não havia outro lugar para procurar respostas. Essa situação não se sustenta mais. Desde a Segunda Guerra Mundial, muitos países adotaram formas de controle de constitucionalidade que, embora diferentes do nosso em muitos aspectos, inequivocamente tem sua origem e inspiração na teoria e na prática constitucional americana. (...). Estes países são nossas crias constitucionais e a maneira como eles têm lidado com problemas análogos aos nossos pode nos ser muito útil quando enfrentamos casos constitucionais difíceis. Pais sábios não hesitam em aprender com seus filhos" (grifou-se).
}

177 1996, 2 S.C.R. 507 
Foram feitas análises detidas de duas decisões do Chief Justice Marshall, da Suprema Corte Americana ${ }^{178}$, quais sejam, Johnson v. M'Intosh ${ }^{179}$ e Worcester v. Georgia $^{180}$, e também do precedente australiano ${ }^{181}$ Mabo v. Queensland ${ }^{182}$.

A partir destes julgados a Corte Canadense fez uma longa explanação e justificou seu recurso aos precedentes estrangeiros, concluindo que os direitos dos aborígenes eram costumeiros, anteriores à ocupação britânica e á própria constituição canadense, bem como regulavam as relações entre sociedades políticas distintas.

Ao final, com base nas conclusões acima mencionadas e com fundamento em outros argumentos desenvolvidos na justificação da decisão, o tribunal canadense determinou que o direito de comercializar peixes não constituía um direito constitucional indígena, pois esta não era uma prática comum aos indígenas antes da chegada dos colonizadores.

Neste caso, a relação histórica acarretou a adoção do precedente estrangeiro. Porém, nem sempre isso é o que acontece, pois ela pode justamente servir para fins de contraste (uso negativo), ou seja, para evidenciar as premissas do próprio ordenamento por meio do confronto com outro que possui as mesmas raízes históricas, o que é muito comum quando há uma ruptura com o antigo regime e se busca afastar práticas consideradas

\footnotetext{
178 “A perspectiva dos direitos indígenas baseada na ocupação anterior da América do Norte por distintas sociedades indígenas encontra apoio nas decisões iniciais do Chief Justice Marshall da Suprema Corte Americana. Embora a estrutura constitucional dos Estados Unidos seja diferente da do Canadá e sua lei indígena tenha se desenvolvido de forma singular, eu concordo com o professor Slattery tanto quando ele descreve as decisões de Marshall como fontes capazes de dotar de 'estrutura e coerência um corpo desarrumado e difuso do direito consuetudinário baseado na prática oficial', como quando ele afirma que essas decisões são 'tão relevantes para o Canadá como para os Estados Unidos' (...) Gostaria de acrescentar aos comentários do Professor Slattery apenas a observação de que o fato de a lei indígena nos Estados Unidos ser consideravelmente diferente da lei indígena canadense significa que a relevância destes casos surge a partir da articulação de princípios gerais, em vez de suas específicas disposições legais" (p. 35-36).

${ }^{179} 21$ U.S. $543-182$

18031 U.S. $515-182$

181 “A Alta Corte da Austrália também já analisou a questão básica aqui posta e a natureza básica dos direitos dos aborígenes. Como o direito norte-americano, o direito aborígene australiano difere em aspectos significantes do direito canadense. Em particular, na Austrália, os tribunais ainda não decidiram se o direito de pescar dos aborígenes existe, embora tais direitos sejam reconhecidos por lei (referências omitidas). Apesar destas relevâncias diferenças a análise da discussão de fundo do precedente Mabo v. Queensland é persuasivo no contexto canadense" (p. 44).
}

182 [No. 2] (1992), 175 C.L.R. 1 
nocivas. Nestas hipóteses percebe-se que os elementos de conexão históricos são utilizados tanto positiva como negativamente, bem como podem se misturar com outros elementos.

Imagine-se, por exemplo, que a Suprema Corte Norte-Americana estivesse a julgar um caso sobre os poderes do Congresso americano frente ao controle de constitucionalidade. Neste exemplo, talvez, uma comparação com a Inglaterra poderia vir a ser interessante, uma vez que os dois países estão historicamente ligados, compartilham valores comuns, mas apresentam estruturas institucionais bastante divergentes. A comparação com o Reino Unido poderia ser proveitosa conforme permitisse aos norte-americanos relembrar os motivos pelos quais se declararam independentes e criaram um Poder Judiciário tão forte, com um Parlamento mais enfraquecido, se comparado ao britânico. Está análise poderia, de alguma maneira, afastar as críticas às decisões contramajoritárias ao rememorar os americanos que umas de suas principais queixas era que, como colônia, eram uma minoria que não tinham seus anseios atendidos pelo Parlamento Britânico ${ }^{183}$.

\subsubsection{As influências estrangeiras na feitura e reforma da constituição e a importação de} legislação

Outro elemento de conexão que pode ser bastante explorado ocorre quando o documento constitucional doméstico ou parte dele foi inspirado ${ }^{184}$ ou teve como base uma constituição estrangeira, bem como quando o legislador ordinário procede à importação de regras e institutos jurídicos.

Embora a inspiração e a importação não sejam novidade, elas se intensificaram fortemente no último século. No que se refere especificamente à seara constitucional, após o fim da Segunda Guerra Mundial inúmeros países adotaram novas constituições e se inspiraram em modelos constitucionais tradicionais, como o americano. Também após a queda do muro do Berlin, com colapso do comunismo, inúmeros países

\footnotetext{
183 DIMOULIS, Dimitri; MARTINS, Leonardo. Teoria Geral dos Direitos Fundamentais. $2^{\mathrm{a}}$ ed. São Paulo: Revista dos Tribunais, 2009, pp. 25-26.

${ }^{184}$ DE VERGOTTINI, Giuseppe. Más allá del diálogo entre tribunale... p. 196.
} 
elaboraram novas constituições, as quais também se basearam, ao menos, parcialmente em outras constituições ${ }^{185}$.

Sem dúvida, tanto na intepretação da própria constituição como na análise do controle de constitucionalidade da legislação ordinária, o recurso à jurisprudência estrangeira sobre o tema inspirador ou importado por se bastante útil e também de fácil justificação.

Assim, quando determinado instituto constitucional tiver inspiração em um documento constitucional estrangeiro ou quando uma reforma constitucional inspirar-se em um paradigma alienígena, a jurisdição constitucional doméstica pode, para interpretar a própria constituição, realizar um estudo acerca de como a corte estrangeira lidou com o mesmo assunto nas suas decisões. Este elo de ligação é de fácil demonstração, o que não significa que o julgado estrangeiro será adotado.

No que concerne a constitucionalidade de legislação importada, esta pode vir a ser questionada em uma série de aspectos, sendo que um estudo sobre como o país exportador lidou com estes problemas pode ser de grande utilidade.

Obviamente não se desconsidera aqui que, muitas vezes, estas importações são feitas de forma acrítica, sem se considerar aspectos relevantes do ordenamento receptor, que podem alterar significativamente a legislação importada. Porém, mesmo quando a assimilação não é feita de maneira cautelosa pelo Poder Legislativo, o conhecimento da fonte inspiradora, bem como a forma como o órgão judicial lidou com ela no ordenamento de origem, podem ser úteis para resolver as questões difíceis sobre a constitucionalidade da legislação importada.

Assim, por exemplo, o Supremo Tribunal Federal, ao analisar a constitucionalidade da Lei $\mathrm{n}^{\circ}$ 11.340/2006 (Lei Maria da Penha) no que se refere a seus artigos 12,16 e $41^{186}$, os quais impunham que os crimes nela previstos apenas fossem processados

\footnotetext{
185 Acerca da influência internacional e estrangeira sobre a elaboração das constituições modernas e sobre a internacionalização do poder constituinte vide: CONI, Luis Cláudio. A internacionalização do Poder Constituinte...

186 “Art. 12. Em todos os casos de violência doméstica e familiar contra a mulher, feito o registro da ocorrência, deverá a autoridade policial adotar, de imediato, os seguintes procedimentos, sem prejuízo daqueles previstos no Código de Processo Penal:
} 
mediante ação penal pública condicionada à representação, poderia ${ }^{187}$ ter analisado a legislação americana sobre a "restraining order", que serviu de inspiração à legislação brasileira $^{188}$. A análise do cenário americano sobre o assunto talvez pudesse jogar luz sobre a difícil questão acerca dos limites da intervenção do Estado sobre a vontade da vítima no que se refere ao seu consentimento para o início da ação penal e da concessão das medidas protetivas de urgência ("restraining orders"). O recurso ao direito e aos precedentes americanos poderia ser útil na medida em que possibilitasse à Corte Brasileira melhor compreender se o consentimento da vítima, no caso a mulher, depende de sua situação econômica e cultural, podendo variar de país para país, ou se é ínsita à condição feminina.

\subsubsection{Questões empíricas}

Uma outra forma de se utilizar precedentes estrangeiros é aquela relativa às questões empíricas, ou seja, analisar quais as consequências de uma decisão que confirma ou afasta a constitucionalidade de uma determinada legislação. Assim, em muitos temas complexos, a experiência de outros países pode ter uma grande relevância.

No já aludido caso Miranda v. Arizona ${ }^{189}$, por exemplo, a Suprema Corte Norte-Americana fez uso do elemento pragmático para justificar a utilização de material estrangeiro.

I- ouvir a ofendida, lavrar o boletim de ocorrência e tomar a representação a termo, se apresentada;

(...)

Art. 16. Nas ações penais públicas condicionadas à representação da ofendida de que trata esta Lei, só será admitida a renúncia à representação perante o juiz, em audiência especialmente designada com tal finalidade, antes do recebimento da denúncia e ouvido o Ministério Público.

(...)

Art. 41. Aos crimes praticados com violência doméstica e familiar contra a mulher, independentemente da pena prevista, não se aplica a Lei n $^{\circ} 9.099$, de 26 de setembro de 1995."

${ }^{187}$ O Supremo Tribunal Federal julgou procedente a aludida ação direta de inconstitucionalidade. Porém, o voto vencedor ainda não foi publicado.

${ }^{188}$ PINHO, Rodrigo Bossi de. A aplicação analógica da Lei Maria da Penha. In Revista da EMERJ, v. 12, n 46, 2009, $\quad$ p. $308 . \quad$ Disponível em: http://www.emerj.rj.gov.br/revistaemerj_online/edicoes/revista46/Revista46_305.pdf.

${ }^{189} 384$ U.S. 436 - 1966 
Como explanado anteriormente discutia-se se a confissão de um crime feito por meio de um interrogatório policial sem se comprovar que o investigado foi informado de que tinha direito a um advogado e podia permanecer em silêncio tinha validade no processo criminal posterior à investigação. Um dos argumentos levantados era de que o reconhecimento desses direitos aos acusados acarretaria menor eficácia da lei criminal, ou seja, dificultaria sua aplicação.

No voto majoritário, elaborado pelo Chief Justice Warren, restou afastado argumento do perigo à aplicação da lei penal nos seguintes termos:

A experiência de outros países também sugere que o perigo à aplicação da lei penal em virtude de restrições ao procedimento do interrogatório policial é superestimado. O procedimento inglês, desde 1912, previsto no "Judges' Rules" (estatuto que regulamenta validade das declarações e confissões feitas na fase da investigação policial) é significativo. Como recentemente reforçado, tais regras exigem que a autoridade policial informe o acusado de seu direito de não se incriminar (direito ao silêncio) e de ter a assistência de um advogado.

As salvaguardas previstas na lei escocesa são ainda mais amplas do que aqueles previstas na Inglaterra. As decisões judiciais escocesas vetam o uso da maioria das confissões obtidas por meio de interrogatório policial. Na Índia, confissões feitas à polícia sem a presença de um magistrado têm sido excluídas por uma regra de 1872, oriunda do tempo que ainda era colônia britânica. Dispositivo idêntico aparece na Ordenação de Evidências do Ceilão, promulgada em 1895. Similarmente, em nosso país, o Código Uniforme da Justiça Militar tem, há tempos, estabelecido que nenhum suspeito poderá ser interrogado sem antes ser advertido de seu direito de não se incriminar. A recusa ao direito de consultar um advogado durante o interrogatório também tem sido rechaçada pelos tribunais militares.

Não parece haver qualquer efeito negativo sobre a aplicação da lei criminal nestas jurisdições em decorrências das regras para a realização do interrogatório. As condições para a aplicação da lei em nosso país são suficientemente similares para permitir a referência a 
estas experiências, as quais nos possibilitam inferir que advertir o indivíduo seus direitos relativos ao interrogatório ou assegurar que ele os exerça não resultará em dificuldade na aplicação da lei penal. Ademais, é consistente com nosso sistema legal que protejamos estes direitos tanto quanto nas jurisdições acima aludidas. Em nosso país a discussão sobre estes direitos se dá com base na décima-quinta emenda da constituição enquanto que as outras jurisdições mencionadas alcançaram suas conclusões com base em princípios de justiça não tão especificamente definidos ${ }^{190}$.

Como se infere do voto majoritário, o estudo de direito e precedentes estrangeiros teve papel importante na fundamentação do voto ao provar, no que tange aos argumentos pragmáticos, que a adoção de determinada legislação não afeta a aplicação da lei penal.

Em outros casos em que aspecto consequencilista também esteja em jogo, o elemento de conexão pragmático pode ser facilmente justificado e utilizado. Assim, no caso concreto do aborto, por exemplo, poderia se discutir se sua liberação resultaria na diminuição do número de mortes de gestantes que o realizam na clandestinidade ou, ainda, prever se sua legalização não geraria um aumento significativo no número de interrupções de gravidez. No caso das ações afirmativas, poderia se aferir se elas realmente alcançaram o fim a que se propunham, ou seja, criar uma sociedade mais igualitária, em que os grupos sociais menos favorecidos alcançassem posições de destaque e melhoras nas condições de vida ou se, por algum motivo, a política de cotas foi insuficiente ou incapaz de promover uma efetiva diminuição nas desigualdades sociais. Os mesmos questionamentos poderiam ser feitos no tocante à liberalização das drogas e suas vantagens e desvantagens sociais.

\subsubsection{Valores Comuns}

Outra circunstância que permite o uso de julgados estrangeiros é o compartilhamento de valores comuns. Ressalte-se que não se cuida de procurar

\footnotetext{
${ }^{190}$ Foram omitidas as inúmeras e completas referências feitas pelo Chief Justice Warren para comprovar suas assertivas referentes ao direito estrangeiro.
} 
convergência de valores com outros sistemas jurídicos, mas de se analisar precedentes de outros ordenamentos que dividem com a jurisdição doméstica valores e aspirações comuns.

Ao que parece, este foi o intuito da Suprema Corte NorteAmericana ao recorrer a precedentes estrangeiros nos polêmicos casos Atkins v. Florida, Lawrence v. Texas e, especialmente em Ropper v. Simmons, ainda que a comparação possa ter sido feita de maneira inadequada e insuficiente.

No último caso, em que se travava uma discussão sobre a possibilidade de aplicar a pena de morte a menores de idade, o voto vencedor fez uma extensiva análise da legislação e jurisprudência de inúmeros países, bem como das tratativas internacionais sobre o assunto ${ }^{191}$. Mencionou inclusive países que condenavam menores à pena capital. É claro, da argumentação exposta no voto, que o intuito era demonstrar que os americanos têm valores em comum com outros povos e que este compartilhamento de valores era justamente o que permitia o uso de material alienígena.

\subsubsection{O uso negativo}

Por fim, é preciso salientar, mais uma vez, que a presença de todos estes elementos de conexão não implica, necessariamente, na adoção do precedente estrangeiro, podendo, ao contrário, resultar na refuta do mesmo. A própria finalidade de recusa de adoção de um precedente estrangeiro pode ser um elemento de conexão, pois tem por fim deixar evidente que uma outra opção não seria adequada ou ideal.

Este foi exatamente o propósito da Corte Constitucional da República Sul-Africana no caso State v. Makwanyane ${ }^{192}$, ao fazer uma longa análise da jurisprudência norte-americana sobre a pena de morte, justamente para, ao final, declará-la inconstitucional no ordenamento sul-africano ${ }^{193}$.

\footnotetext{
191 Não se ignora que os tratados e documentos internacionais mencionados no voto majoritário não foram aprovados ou o foram com reservas pelo Congresso dos Estados Unidos, o que, sem dúvidas, é uma situação problemática no julgado. No entanto, a decisão é acertada no que se refere à tentativa de justificar o uso de material estrangeiro com base em valores comuns que os Estados Unidos compartilham outros Estados.

${ }^{192}$ Case No. CCT/3/94

${ }^{193}$ Vale mencionar que não foi apenas a jurisprudência americana que foi analisada. Recorreu-se também a material indiano, canadense, alemão e da Corte Europeia de Direitos Humanos, entre outros.
} 
Chief Justice Chaskalson, por exemplo, em seu voto, fez uma abordagem histórica e jurisprudencial do direito americano sobre a pena de morte cotejando esta análise com o direito e a realidade sul-africana. Cuidadosamente apontou uma série de fatores que distanciavam os dois países: a diferença nos processos criminais; a discrepante facilidade/dificuldade de acesso à defesa adequada; a situação de pobreza dos negros, os objetivos da nascente nação sul-africana. Também mencionou que a constituição americana, apesar de conter dispositivo vedando a imposição de penas cruéis e incomuns, não consagra o valor da dignidade humana. Com base, neste e em outros argumentos, decretou a inconstitucionalidade da pena de morte na África do Sul, no que foi seguido pela maioria do Tribunal.

Outro exemplo de uso negativo ocorreu no caso canadense Regina v. Keegstra ${ }^{194}$, no qual se discutia a constitucionalidade de dispositivo do Código Penal que criminalizava o discurso do ódio, sob a alegação de que ocorreria ofensa ao princípio da liberdade de expressão.

No voto majoritário foi feita uma cuidadosa análise da jurisprudência americana sobre o assunto por considera-la útil e por respeito ao seu histórico. Porém, ao final, após o devido cotejo, o tribunal canadense rejeitou a posição americana, por entender que sociedade canadense busca promover valores em jogo de maneira diferente da forma realizada pelos Estados Unidos ${ }^{195}$.

\footnotetext{
${ }^{194}$ [1990] 3 S.C.R. 697

195 “A questão referente a este recurso não é, logicamente, como é ou deveria ser o direito dos Estados Unidos. Mas é importante explicitar as razões pelas quais a experiência americana pode ou não ser útil (....). Nos Estados Unidos uma lista de direitos fundamentais tem sido protegida por mais de duzentos anos. O resultado prático e teórico da experiência americana é imenso e não deve ser desconsiderado pelas cortes canadenses. Por outro lado, nós devemos examinar o direito constitucional americano com olhos críticos (...).
}

(...)

Canadá e Estados Unidos não são parecidos em muitos aspectos e seus documentos constitucionais não estabelecem direitos humanos que surgiram em contextos idênticos. Basta o senso comum para reconhecer que, da mesma forma que as similaridades justificam os empréstimos tomados da experiência americana, as diferenças podem demandar que a visão constitucional do Canadá aparte-se daquela adotada nos Estados Unidos" (p. 4748). 


\subsubsection{Critérios: síntese conclusiva}

A título de conclusão, portanto, pode-se dizer que as balizas que devem servir de parâmetros para o uso de precedentes estrangeiros são:

a) a desnecessidade de autorização constitucional expressa;

b) o precedente estrangeiro jamais pode ser utilizado para contrariar o texto constitucional quando este for claro e evidente e pode ser usado quando o texto constitucional for vago e indeterminado;

c) o consenso mundial sobre determinado assunto não autoriza, por si só, o uso de precedentes estrangeiros, sendo mero indicativo a ser, eventualmente observado, servindo, neste caso, de reforço lógico; e, no caso, de rejeição, de elemento capaz de jogar sobre a corte o ônus argumentativo pelo afastamento;

d) os precedentes estrangeiros podem ser utilizados tanto em questões pragmáticas, como em assuntos jurídico-morais;

e) os elementos de conexão que permitem o manejo de precedentes estrangeiros são variados, apenas aferíveis no caso concreto e podem ser cumuláveis;

f) os elementos de conexão mais comuns são: a relação histórica entre países, as influências estrangeiras na feitura da constituição e a importação de legislação, questões empíricas, o compartilhamento de valores comuns, e as similaridades ou diferenças entre as nações

Duas últimas observações precisam ser feitas.

Os elementos de conexão aqui descritos não são exaustivos, o que significa dizer que outros podem ser detectados. Simplesmente, estes foram os elementos encontrados com mais constância e que emergiram do estudo feito até o momento, 
Outrossim, também deve restar claro que a presença de um ou vários elementos de conexão não implica na obrigação de realizar a comparação, nem na utilização positiva de precedentes estrangeiros. Como já asseverado, a utilização de julgados alienígenas é algo facultativo, uma ferramenta útil a ser considerada.

\subsection{AS FORMAS DE UTILIZAÇÃO DOS PRECEDENTES ESTRANGEIROS}

O principal problema relativo ao uso de precedentes estrangeiros é justamente o modo como ele é efetivado. Como se verá no capítulo seguinte, o uso de precedentes pelo Supremo Tribunal Federal é, em geral, feito de maneira injustificada e assistemática, sem quaisquer esclarecimentos. Desta maneira, a forma como devem ser manejados os precedentes estrangeiros é ponto nodal de uma metódica que fundamente e justifique o uso de precedentes alienígenas. Isto porque é justamente a demonstração dos elementos de conexão (transparência), a contextualização do precedente (significado) e a pertinência (comparação) de seu uso que irão legitimar o diálogo constitucional como mais uma ferramenta na tarefa de interpretar uma constituição.

Inicialmente é importante reiterar que o presente trabalho tem como premissa a utilização de precedentes estrangeiros com base no modelo dialógico, sendo que o recurso ao material alienígena de maneira isolada na atividade de interpretação da constituição é inaceitável, até porque, se se parte de um ponto de vista comparativo, o olhar para "si" e para o "outro" é algo imprescindível na tarefa de comparar, que engloba tantos as semelhanças como as diferenças (aquilo que torna algo único e comum ao mesmo tempo ${ }^{196}$ ).

Desta forma, o uso de precedentes estrangeiros que, de alguma forma, implique nos modos de submissão, repulsa, universal ou decorativo deve ser, de plano, afastado, pois a finalidade ou resultado destes modos de utilização de material alienígena é,

\footnotetext{
${ }^{196}$ Em artigo extremamente interessante, intitulado "Comparative Law as Comparative Jurisprudence - The Comparability of Legal Systems" (Disponível em: <http://ssrn.com/abstract=385861> ou $<$ http://dx.doi.org/10.2139/ssrn.385861), Catherine Valcke aponta que a ideia de comparabilidade pressupõe unidade e pluralidade. Para ela "a comparação apenas é possível entre objetos que são, simultaneamente, mas sem contradição, unidade e plural. Ao contrário a um antigo ditado, laranja e maçãs são comparáveis, ao menos em alguns aspectos" (p. 07). É justamente a antinomia unidade/pluralidade que permite a comparação. Desta feita o sistema legal apenas é comparável quando for simultaneamente único e plural, ou seja, ao mesmo tempo "self" e "outro".
} 
respectivamente, ignorar as diferenças; desconsiderar as similaridades; sobrepor, de maneira indevida, as semelhanças em prejuízo das diferenças e, por último, não realizar comparação alguma.

Postas essas considerações e vislumbrando algum ou alguns elementos de conexão que permitam a interlocução constitucional é preciso implementá-la de forma a legitimá-la. É necessário, em outras palavras, evidenciar os elementos de conexão e demonstrar qual a finalidade de interagir com uma ou com várias cortes estrangeiras.

Desta feita, uma forma transparente, ordenada e coerente de se utilizar o material estrangeiro deve ter ao menos as seguintes fases: a explicitação do(s) elemento(s) de conexão que possibilitam a interlocução constitucional; a contextualização e a pertinência. Cada uma delas será analisada a seguir.

\subsubsection{A demonstração do(s) elemento $(s)$ de conexão}

Antes de mais nada, o juiz ou a corte constitucional, ao entenderem que o uso de precedentes estrangeiros pode ser de grande valia, devem apontar as razões que o levaram a olhar para fora do próprio ordenamento. É nesta oportunidade em que se deve apresentar o elo entre os dois ordenamentos em comparação, deixando claro aquilo que permite uma interlocução constitucional produtiva, ou seja, o porquê de se recorrer a experiência estrangeira.

Como já dito, a seletividade em si não é um empecilho e não há nada de problemático em o julgador optar por engajar-se numa conversa constitucional com um país cujo ordenamento jurídico lhe seja familiar. Não há como se negar a própria contingência do conhecimento do julgador, de sua formação, ou das oportunidades de interação com outras cortes que o juiz teve anteriormente ${ }^{197}$.

\footnotetext{
197 Giuseppe de Vergottini reconhece que o "argumento comparativo tem sua utilização condicionada por específicos fatores culturais (relações entre os operadores das áreas culturais afetadas, difusão intercultural da literatura jurídica, disponibilidade dos operadores para acolher instâncias que tendem a dar uniformidade aos direitos) e sócios-organizativos (grau de desenvolvimento dos Estados a cujos ordenamentos se referem, tradições jurídicas, políticas do Direito dos quais os documentos normativos são expressões" (Más allá del diálogo entre tribunales - Comparación y relación entre jurisdicciones..., p. 282-283)
} 
Contudo, o problema surge quando se decide simplesmente citar um precedente estrangeiro de maneira ornamental, não evidenciando as razões que levaram àquela citação, seja para um uso positivo ou negativo, ou quando meramente se faz a citação por ter familiaridade com o ordenamento fornecedor do precedente, mas sem qualquer efeito prático sobre o resultado do julgamento.

Desta feita, a demonstração do elemento de ligação tem justamente por fim evitar citações de precedente estrangeiro destituídas de qualquer finalidade argumentativa, bem como explicitar como os precedentes estrangeiros citados, quando influenciaram a decisão, relacionavam-se com a celeuma constitucional em julgamento.

\subsubsection{A contextualização}

Num segundo momento, deve ser exposto pelo tribunal um resumo do caso julgado pela corte estrangeira, demonstrando-se, ainda que sucintamente, os aspectos normativos e fáticos que envolveram o precedente citado.

Em seguida, deve o julgador proceder à contextualização, isto é, apontar eventuais fatos e elementos jurídicos e extrajurídicos que possam ter influenciado a decisão estrangeira.

Esta fase é de extrema importância, pois conforme ensina José Afonso da Silva, com base em Jorge Miranda, a contextualização, que é por ele denominada de "necessidade de localização", é pressuposto da comparabilidade e consubstancia-se na "necessidade de raciocinar dentro dos quadros conceituais e técnicos do direito constitucional donde se isolam os institutos objecto da comparação, e necessidade de contemplar as condições de aplicação das normas no ambiente e no estágio social em causa" 198 .

Com efeito, a tarefa de contextualização do julgado é extremamente importante justamente porque tem por finalidade constatar o que Mark

${ }^{198}$ MIRANDA, Jorge. Notas para uma introdução ao direito constitucional comparado. Lisboa, 1970, p. 42. APUD SILVA, José Afonso da. Direito Constitucional Comparado e Processo de Reforma do Estado. Disponível em: http://biblio.juridicas.unam.mx/libros/4/1793/14.pdf, p. 273. 
Tushnet ${ }^{199}$ e Vlad Perju ${ }^{200}$ denominam de "modularidade", ou seja, aferir o fundamento e o significado do precedente estrangeiro dentro do ordenamento jurídico de origem, pois para estes autores, é imprescindível, para se efetuar uma comparação adequada, sempre considerar a contingência do significado de determinada norma ou instituição por uma estrutura maior que lhe dá efetivo significado.

Esta fase de contextualização é de suma importância para se compreender o julgado estrangeiro e evitar a armadilha de se subestimar a relação entre a decisão e o contexto, fazendo-se o mau uso do precedente estrangeiro.

Os dois autores estrangeiros já mencionados citam exemplos em que há grande distância entre o discurso e a prática constitucional, como ocorre, de forma mais evidente, na África, onde é comum encontrar "constituições sem constitucionalismo”, ou seja, textos e decisões constitucionais que não têm substrato político e cultural. Precedentes oriundos de cenários como este não são inutilizáveis, mas sua análise demanda uma cautela maior.

Portanto, a fase de contextualização tem a função de permitir ao julgador doméstico entender, ainda que dentro de suas limitações intelectuais, de maneira mais isenta possível, o significado de determinada decisão constitucional em sua jurisdição de origem, permitindo-se desta forma que se compreenda o precedente estrangeiro não meramente em sua dimensão normativa, mas também nos aspectos políticos, sociais, econômicos e culturais.

Para a realização de uma contextualização efetiva e racional é preciso, conforme leciona José Afonso da Silva, conhecer e compreender ${ }^{201}$ o material estrangeiro que se pretende usar.

Numa primeira etapa, a de conhecimento, deve se observar as seguintes regras ${ }^{202}$ :

\footnotetext{
${ }^{199}$ Returning with Interest: Observations on Some Putative Benefits of Studying Comparative Constitutional Law. 1 University of Pennsylvania Journal of Constitutional Law 325, 330, 1998.

${ }^{200}$ Constitutional Transplants...

${ }^{201}$ Ibidem (SILVA), p. 275-276

${ }^{202}$ Ibidem.
} 
1) examinar o termo a comparar tal como ele é;

2) estudar o termo a comparar nas suas fontes originais e autênticas;

3) estudar o termo a comparar na complexidade e na totalidade das fontes jurídicas que, na ordem jurídica respectiva, concorrem para formular, precisar e aplicar a regra de direito constitucional, mas deve se buscar a prática real da regra constitucional;

4) respeitar a hierarquia das fontes jurídicas própria do ordenamento constitucional a comparar ou de que faz o elemento a comparar;

5) empregar o método de interpretação empregado no ordenamento constitucional a comparar.

Posteriormente, deve se passar à fase de compreensão, a qual é "tarefa mais delicada", pois "o comparatista constitucional precisa conhecer os elementos fundamentais do ordenamento constitucional e seus elementos determinantes, mas também certos elementos de natureza meta-jurídica que formam o meio político, econômico e social próximos $^{203}$.

Por fim, o magistrado que invocar material alienígena deve tomar cuidado ao fazê-lo, buscando evitar elucubrações próprias que contaminem a compreensão do significado do julgado, pois tal conduta, ademais de ser discutível, se afasta de um "método interpretativo rigoroso que deve estar baseado em um processo valorativo e volitivo explícito, e portanto, sujeito ao confronto, por parte do sujeito que lhe executa"204

\subsubsection{A pertinência: a possibilidade de adoção do precedente estrangeiro}

Compreendido o precedente estrangeiro, deve ser demonstrada pelo tribunal ou magistrado, a pertinência da comparação entre os julgados, isto é deve ser analisada o quão pertinente é o uso do material alienígena para a solução da controvérsia constitucional doméstica.

\footnotetext{
${ }^{203}$ Ibidem

${ }^{204}$ DE VERGOTTINI, Giuseppe. Más allá del diálogo entre ..., p. 249-250.
} 
A pertinência, na realidade, é a comparação em si, isto é, ela tem uma função relacional na medida em que, após aferido o significado do precedente estrangeiro em seu ambiente original (contextualização), deve este mesmo significado ser confrontado e cotejado com ordenamento jurídico doméstico.

A função da etapa de demonstração da pertinência é verificar se o julgado estrangeiro pode, ante o contexto doméstico e estrangeiro, ser usado pelo tribunal, evitando-se uma utilização acrítica que nada colabora com a efetividade da decisão.

Feita adequadamente, a pertinência poderá afastar decisões que se confrontam com o ordenamento doméstico, tanto do ponto de vista formal, como jurídicomoral, bem como evitar que se tomem decisões que não terão efetividade no ambiente doméstico em virtude de diferenças substanciais entre os países em comparação.

Como já asseverado, é muito comum ver países subdesenvolvidos importando doutrinas e decisões de países desenvolvidos, desconsiderando totalmente o substrato cultural que permitiu que aquela legislação alcançasse seus objetivos.

Certamente, se observados as etapas aqui descritas a chances de utilização equivocada ou de mau uso do direito estrangeiro (em especial nos modos de submissão e decorativo) serão bastante reduzidas.

Um exemplo em que houve uma adequada utilização de jurisprudência estrangeira foi no polêmico caso americano Lawrence v. Texas, no qual se discutia constitucionalidade da lei texana que criminalizava condutas homossexuais, quando a Suprema Corte decidiu superar a decisão Bowers v. Hardwick ${ }^{205}$, que declarara constitucional este tipo de legislação. A decisão da década de oitenta teve como fundamento, entre outros, o argumento de que a história e a tradição da civilização ocidental, da qual os Estados Unidos faziam parte, condenavam a conduta homossexual, sendo, portanto, constitucional que o Estado criminalizasse tal conduta. Na decisão mais recente, o voto majoritário fez uma narrativa sobre os valores da civilização ocidental e, em seguida, recorreu a julgados da Corte Europeia de Direitos Humanos que haviam condenando a Inglaterra e a Irlanda a revogarem suas legislações antissodomia, para demonstrar, justamente, o equívoco de Bowers. Foram, nesta oportunidade, evidenciados os valores compartilhados pelos EUA. com os demais países

205478 U. S. $186-1986$ 
ocidentais, especialmente os europeus, bem como detalhados os precedentes europeus citados. Ao final, restou clara a pertinência da comparação.

É inegável que a sistemática usada pela Suprema Corte Americana realizou cada um dos passos aqui aludidos e, por isso, o uso de precedentes estrangeiros foi legítimo.

Da leitura do acórdão percebe-se que o elemento de conexão foi o compartilhamento de valores comuns (em especial com os países europeus) que auxiliaram a Suprema Corte Norte-Americana a melhor compreender e articular os compromissos americanos com a liberdade e com a igualdade. A partir deste elemento de conexão foi analisada a jurisprudência antiga e atual da Corte Europeia de Direitos Humanos, para restar claro que a decisão anterior, proferida em Bowers era equivocada.

Obviamente a decisão não está exatamente estruturada da forma aqui sugerida e poderia ter se aproveitado mais dos precedentes estrangeiros invocados. No entanto, é de fácil aferição que voto que norteou a decisão procurou analisar cuidadosamente o precedente estrangeiro, demonstrar sua compatibilidade com o ordenamento doméstico e fazer um uso positivo do entendimento alienígena.

O mesmo ocorreu quando a Corte Sul-Africana julgou a constitucionalidade da pena de morte, no caso State. $v$ Makwanyane, onde, como já mencionado em item anterior, foi feita uma longa análise da jurisprudência norte-americana sobre o assunto, para ao final, depois de demonstradas que as premissas fundantes de cada um dos ordenamentos em comparação divergiam no tocante a esse ponto, declarar a inconstitucionalidade da pena capital no ordenamento sul-africano (utilização negativa de precedentes estrangeiros).

\subsection{Síntese das etapas para a utilização de precedentes estrangeiros}

Postas estas considerações, os passos aqui sugeridos para um uso legítimo racional de precedentes estrangeiros são:

a) demonstração do elemento de conexão entre o ordenamento doméstico e o estrangeiro; 
b) Contextualização (modularidade) do julgado alienígena para se aferir seu real significado;

c) demonstração da pertinência da comparação a ser levada a cabo;

d) sempre, ao se recorrer ao uso de precedentes estrangeiros, evitar os modos de submissão, repulsa, universal ou decorativo

Além desses passos, há algumas observações de caráter formal, as quais reforçam a aplicação dos fundamentos e critérios até aqui explanados, e que também devem ser seguidas:

a) evitar o uso indireto de precedentes estrangeiros, ou seja, citar um precedente com base na leitura de uma doutrina como se tivesse lido a decisão estrangeira;

b) conferir se o precedente citado não foi superado ou se ele não uma decisão isolada e casuística que não reflete o real posicionamento da corte estrangeira;

c) evitar o uso de voto vencido como se fosse um precedente.

d) evitar o uso de precedentes oriundo de corte cuja posição ainda não esteja consolidada (jurisprudência instável).

Espera-se que, observando-se todas estas etapas, que visam dar transparência ao uso de precedente estrangeiro e permitir que seja aferido qual seu impacto sobre a decisão alcançada, as jurisdições constitucionais possam fazer um uso legítimo e racional dos precedentes estrangeiros. 


\section{PRECEDENTES ESTRANGEIROS NA JURISDIÇÃO DO SUPREMO TRIBUNAL FEDERAL}

\subsection{HISTÓRICO E PANORAMA NORMATIVO E JURISPRUDENCIAL BRASILEIROS}

Historicamente, em virtude do fato do Brasil ser um país do novo mundo e ter sido colônia por mais de trezentos anos, o uso de direito estrangeiro em seu sentido mais amplo era comum. Na verdade, o direito português que pautava o direito na colônia foi, em seus primeiros dois séculos, um direito medieval, fortemente influenciado pelo Direito Canônico e Romano. Ainda no final do século XVIII, sob os auspícios do Marquês de Pombal, época influenciada fortemente pelo iluminismo e pelo jusnaturalismo, foi promulgada a Lei da Boa Razão ${ }^{206}$, de 18 de agosto de 1769, a qual teve por fim afastar o fundamento jurídico do direito consuetudinário, eliminar a relevância do direito canônico, restringir o domínio de aplicação do direito romano, impor que da boa razão advinha também "outras regras, que, de unânime consentimento, estabeleceu o direito das gentes, para direcão $\boldsymbol{e}$ governo de todas as nacões civilizadas" e por fim, estabelecer que, no caso de lacuna, sua resolução também "se estabelece(sse) nas leis políticas, econômicas, mercantis e marítimas, que as nacões cristãs têm promulgado".

Mesmo após a independência do Brasil em 1822, a Lei da Boa Razão ainda vigia em território nacional, pois a Lei de 20 de outubro de $1823^{207}$ dispunha que a legislação portuguesa, entre elas a mencionada lei iluminista, era plenamente aplicável na nova nação.

Posteriormente, após Declaração da República, em 1889, com o intuito de a nascente Justiça Federal Brasileira, foi promulgado o Decreto ${ }^{\circ}$ 848, de 11 de outubro de $1890^{208}$, em cujo art. 386 estava disposto que:

\footnotetext{
206 Disponível no site da Faculdade de Direito da Universidade de Lisboa: http://www.google.com.br/url?sa=t\&rct=j\&q=\&esrc=s\&source=web\&cd=1\&cad=rja\&ved=0CDAQFjAA\&url=h ttp\%3A\%2F\%2Fwww.fd.unl.pt\%2Fdocentes_docs\%2Fma\%2Facs_MA_5058.doc\&ei=KhDHUO_IJoo8ATh8oF4\&usg=AFQjCNE_UI2gTyAV-PeOBhhPU0PEf_3yTw.

${ }^{207}$ Disponível em: http://www.camara.gov.br/Internet/InfDoc/conteudo/colecoes/Legislacao/Legimp-F_80.pdf.

${ }^{208}$ Disponível em: http://www2.camara.leg.br/legin/fed/decret/1824-1899/decreto-848-11-outubro-1890-499488publicacaooriginal-1-pe.html.
} 
Art. 386. Constituirão legislação subsidiaria em casos omissos as antigas leis do processo criminal, civil e commercial, não sendo contrarias ás disposições e espirito do presente decreto.

Os estatutos dos povos cultos e especialmente os que regem as relações juridicas na Republica dos Estados Unidos da America do Norte, os casos de common law e equity, serão tambem subsidiarios da jurisprudencia e processo federal. (grifou-se)

Logo, desde a época da colônia, o direito estrangeiro era elencado como fonte de interpretação do direito doméstico e, no início da República, o direito dos povos cultos, em especial, o direito americano, foi, de alguma maneira, fonte formal do direito brasileiro ${ }^{209}$.

Vale frisar que as constituições brasileiras, inclusive aquelas contemporâneas às já aludidas leis, como a constituição imperial de 1824 e a constituição da República de 1891, foram silenciosas em relação ao uso de direito estrangeiro na interpretação do direito nacional. Em outras palavras, constitucionalmente nunca houve previsão expressa sobre o uso de direito ou precedentes estrangeiros no ordenamento jurídico brasileiro,

\footnotetext{
${ }^{209}$ Neste sentido aponta Carlos Bastide Horbach:

“(...) a jurisdição constitucional brasileira nasce sob o influxo marcante do direito estrangeiro, em especial do direito norte-americano. Ante o transplante abrupto de instituições republicanas e presidencialistas para um ambiente cultural orientado por anos e anos de práticas constitucionais monárquicas e parlamentaristas, natural que a doutrina e a jurisprudência de países experimentados nessas "novidades" fossem a fonte mais fácil e confiável na interpretação e na aplicação da ordem constitucional da República.
}

A partir de então acúmulo de referências estrangeiras é uma das características mais constantes dos votos de ministros do Supremo Tribunal Federal, seja nos primeiros anos da República, seja em suas fases de consolidação democrática, em seus momentos de crise institucional, seja nos dias de hoje.

A própria jurisdição constitucional evoluiu sob a égide das experiências estrangeiras, de modo que, gradualmente, essa evolução passa a ser refletida na origem dos autores e dos precedentes citados nos votos, os quais cada vez menos se referem a nomes americanos, trocando-os por autores e cortes da Europa (nota omitida)

Assim, é possível dizer que a jurisdição constitucional brasileira que nasce no final do século XIX e no início do século XX teve seu exercício marcado pelo direito estrangeiro, sendo o recurso a normas, autores e precedentes de outros países ainda um de seus traços marcantes no início do século XXI.” (In:.Referências estrangeiras são constante no STF. Disponível em: http://www.conjur.com.br/2012-nov-10/observatorio-constitucionalreferencias-estrangeiras-sao-constante-stf) 
existindo apenas dispositivos infraconstitucionais que, de alguma forma, incentivavam ou permitiam o uso de material alienígena ${ }^{210}$.

Apenas com a Constituição de 1988 o direito internacional e estrangeiro, este ainda que de maneira indireta, passaram a ser explicitamente mencionados e ligados aos direitos humanos.

Inegavelmente a Constituição Federal de 1988 impõe, de alguma forma, a obrigação ao Estado brasileiro de olhar à sua volta e não se isolar ao estabelecer que “a República Federativa do Brasil buscará a integração econômica, política, social e cultural dos povos da América Latina, visando à formação de uma comunidade latino-americana de nações" (art. $4^{\circ}$, parágrafo único), que "os direitos e garantias expressos na Constituição brasileira não excluem outros decorrentes do regime e dos princípios por ela adotados, ou dos tratados internacionais em que a República Federativa do Brasil seja parte" ( $\left(2^{\circ}\right.$, do art. $5^{\circ}$ ), que "os tratados e convenções internacionais sobre direitos humanos que forem aprovados, em cada Casa do Congresso Nacional, em dois turnos, por três quintos dos votos dos respectivos membros, serão equivalentes às emendas Constitucionais" $\left(\S 3^{\circ}\right.$, do art. $\left.5^{\circ}\right)$, ainda, que "o Brasil se submete à jurisdição do Tribunal Penal Internacional a cuja criação tenha manifestado adesão" ( $\left(4^{\circ}\right.$, do art. $\left.5^{\circ}\right)$ e, por fim, que "O Brasil propugnará pela formação de um tribunal penal internacional dos direitos humanos” (ADCT, art. $7^{\circ}$ ).

Ainda que os artigos constitucionais mencionados se refiram especificamente ao direito internacional e aos direitos humanos na órbita internacional e que pareçam buscar uma integração formal com as outras nações, em especial com as da América Latina, não há como se desconsiderar que, de certa forma, há um incentivo à colaboração mútua entre os países, e, no caso do Poder Judiciário, entre as Cortes Constitucionais ou Supremas Cortes.

Ademais, como já explicado anteriormente, a utilização de precedentes estrangeiros pelo Supremo Tribunal Federal não demanda autorização expressa da Constituição, uma vez que, ao ver deste trabalho, esta autorização, nos dias de hoje, resta

\footnotetext{
${ }^{210}$ Historicamente percebe-se que nestas épocas o direito estrangeiro e dos povos cultos era, de certa forma, visto como algo superior e seu uso era recomendado em virtude de um certo sentimento de inferioridade intelectual brasileiro.
} 
implícita, na medida em que negar esta possibilidade não resolveria o problema, apenas o "varreria para debaixo do tapete", continuando a existir. Em resumo, negar a realidade atual, na qual os atores jurídicos mundiais são mais próximos e no qual a formação jurídica é mais cosmopolita, seria ignorar problemas constitucionais que precisam ser enfrentados. Por fim, além destes motivos, tem-se também que o isolamento do resto do mundo empobrece as possibilidades do discurso jurídico, o que se confronta com o estipulado no Título I (artigos $1^{\circ}$ a $4^{\circ}$ ) da Lei Maior brasileira, que elenca entre os valores da República o pluralismo e a diversidade cultural, que, certamente, têm muito a ganhar com o uso de precedentes estrangeiros.

Demonstradas as premissas normativas que inserem o Brasil e seu ordenamento jurídico no diálogo constitucional é preciso analisar como o Supremo Tribunal Federal vem utilizando os precedentes estrangeiros no controle de constitucionalidade.

Embora o presente trabalho não tenha qualquer ambição estatística ou quantitativa, a apresentação de alguns dados é relevante para se ter uma real dimensão do fenômeno ora pesquisado em terras brasileiras.

Uma simples pesquisa ${ }^{211}$ no site da Corte Constitucional Brasileira evidencia o fenômeno do uso de precedentes estrangeiros. Restringindo-se a busca ao período referente apenas a este novo milênio, descobre-se que 23 acórdãos fizeram referência ${ }^{212}$ ao termo "Suprema Corte Americana" e outros 18 arestos apontaram alguma ligação com o termo "Suprema Corte dos Estados Unidos". A palavra "Bundesverfassungsgericht" (Tribunal Constitucional Alemão) e abreviação desta mesma palavra ("BVerfGE”) constaram, respectivamente, de 20 e 23 acórdãos prolatados nos últimos 11 anos. No tocante específico às Cortes Supranacionais, Corte Interamericana de Direitos Humanos e Corte Europeia de Direitos Humanos, 14 julgados fizeram menção expressa a elas. Vê-se, portanto, por meio desta simples pesquisa ilustrativa, que o Supremo Tribunal Federal

\footnotetext{
${ }^{211}$ Esta pesquisa foi elaborada em maio de 2011. Houve uma tentativa de atualizá-la, mas o site do Supremo Tribunal Federal indica que os termos "Suprema Corte Americana" e "Suprema Corte dos Estados Unidos" são argumentos inválidos.

${ }^{212} \mathrm{O}$ termo referência, nesta frase, tem sentido amplo e pode ser entendido como indicação direta ou indireta de uma fonte de direito externa ao ordenamento jurídico brasileiro, que pode ser invocada como obter dictum, razão de decidir ou apenas como mera menção.
} 
vem, com certa frequência, invocando fontes externas ao ordenamento jurídico brasileiro, para fundamentar e justificar suas decisões.

Guilherme Amorim Campos da Silva, que se dedicou à pesquisa deste tema de maneira mais ampla, não se restringindo apenas aos precedentes estrangeiros, mas também aos internacionais, encontrou ${ }^{213}$, até 2010 , quarenta e cinco acórdãos ${ }^{214}$ em que o Supremo Tribunal Federal usa precedentes estrangeiros em sentido amplo como razão de decidir ou argumento de convencimento. Em seu trabalho de doutorado, o mencionado pesquisador notou um aumento progressivo no uso de precedentes estrangeiros pelos ministros do Supremo Tribunal Federal, em especial nos últimos cinco anos ${ }^{215}$.

Sua pesquisa também identificou que o uso de precedentes estrangeiro e internacionais ocorre tanto no controle de constitucionalidade abstrato como no concentrado. Além disso, constatou que os ministros que mais recorrem aos precedentes alienígenas são Celso de Mello e Gilmar Mendes, e que as Cortes mais citadas são a Suprema Corte Americana e o Tribunal Constitucional Alemão.

Também por meio de uma pesquisa junto ao site "Observatório

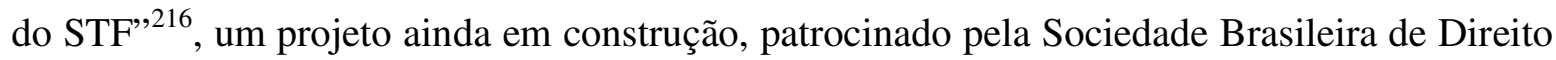

\footnotetext{
213 Tanto em controle constitucionalidade abstrato, como no concreto. Importante frisar que este pesquisador ressalva que sua pesquisa não foi exaustiva.

${ }^{214}$ Os julgados estudados foram os seguintes (que tratam tanto de precedentes estrangeiros, como internacionais): HC 79589 (direito de permanecer em silêncio - 2000); HC 79812 (direito de permanecer em silêncio - 2000), HC 82424 (Caso Ellwanger - 2003); MC ADI 2551 (Vedação ao Confisco - 2003); HC 84203 (uso de prova ilícita - 2004); ADI 3105 (Tributação dos Inativos - 2004); RE 442683 (Possibilidade de efeito "ex nunc" no controle de constitucionalidade - 2005); RE 390840 (direitos do contribuinte - 2005); RE 346084 (direitos do contribuinte - 2005); MC MS 25647 (decoro parlamentar - 2005); MC MS 25579 (decoro parlamentar - 2005); HC 82788 (prova ilícita - 2005); RE 413782 (Poder de Intervenção do Estado e obrigações acessórias à obrigação tributária - 2005); ADI 2797 (Verticalização de Efeitos no Poder Judiciário - 2005); HC 87654 (crime contra a ordem econômica - 2006); HC 82959 (Individualização e Progressão da Pena - 2006); HC 90376 (prova ilícita - 2007); RE 370682 (crédito presumido - direito tributário - 2007); ADI 3112 (Estatuto das Armas 2007); AgRRE 587604 (PIS/COFINS - sociedade de advogados - isenção - 2008); RE 349703 (Prisão Depositário Infiel / Supralegalidade do Tratados - 2008); MS 23441 (Princípio do Contraditório e Ampla Defesa - 2008); HC 94016 (Devido processo legal - 2008); HC 93050 (utilização de prova ilícita - 2008) ADI 3999 (Direitos Políticos - Perda de cargo Eletivo - decisão do TRE - 2008); ADI 3937 (Comercialização de Amianto - 2008); ED-RE 592.148 (Direito Tributário/Direito dos Contribuintes - 2009); Reclamação 6568 (Direito de Greve de Servidor Público - 2009); Petição 3388 (Petição Raposa Serra do Sol - 2009); HC 91676 (privação de liberdade/trânsito em julgado - 2009); RE 466343 (Depositário Infiel - 2008); ADI 1194 (Vinculo Empregatício do Advogado - 2009); ADPF 130 (Lei de Imprensa - 2009); ADPF 153 (Lei de Anistia - 2010).

${ }^{215}$ Idem, ibidem, pp.. 97-99.

${ }^{216}$ www.observatoriodostf.org.br/acoes
} 
Público, é possível constatar o uso de precedentes estrangeiros pelo Supremo Tribunal Federal.

Este site permite fazer uma pesquisa que abarca 267 acórdãos da Corte Constitucional brasileira, proferidos em julgamento definitivo de ações de controle concentrado de constitucionalidade de normas (ações diretas de inconstitucionalidade, ações diretas de constitucionalidade e argüições de descumprimento de preceito fundamental), referentes ao período compreendido entre 21.06.2006 e 10.01.2010.

Ao se marcar o filtro "direito comparado", a pesquisa aponta que 8 acórdão recorreram a material estrangeiro em seus fundamentos ${ }^{217}$. Outras pesquisas no site também confirmam as constatações feitas por Guilherme Amorim Campos da Silva de que os ministros que mais citam precedentes estrangeiros são Gilmar Mendes e Celso de Mello e que os países cujo direito é mais invocado são Alemanha e Estados Unidos.

Como o presente trabalho se propôs a fazer uma análise do fenômeno da utilização de precedentes estrangeiros pelo Supremo Tribunal Federal, considerando que há uma miríade de decisões em que houve citação de precedentes estrangeiros e que seria de impossível análise em um único trabalho, optou-se em restringir a análise a cinco decisões recentes (posteriores ao ano 2000) e que ilustram bem as críticas e os critérios aqui expostos.

Desta forma, procedeu-se à leitura de dez decisões: HC 82.424/Caso Ellwanger (2003), ADPF 54/Caso do Aborto de Feto Anencéfalo (2005), ADI 2797/Improbidade Administrativa (2005), ADI 3937/ Comercialização de Amianto (2008), ADPF 130/Lei de Imprensa (2009), RE 511.961/Diploma de Jornalista (2009), ADPF 153/Lei de Anistia (2010), ADPF 132/União Homoafetiva (2011), ADI 4.578/ Lei da Ficha Limpa (2012), ADPF 186/Ações Afirmativas (2012). Essa primeira seleção ocorreu em função de dois critérios: ciência de que elas mencionavam precedentes ou assuntos recentes e polêmicos propícios à citação de precedentes estrangeiros.

Efetuada a leitura de todas estas decisões optou-se por analisar cinco delas neste trabalho: HC 82.424/Caso Ellwanger, ADPF 54/Caso do Aborto de Feto

\footnotetext{
${ }^{217}$ ADI 2240, ADI 3089, ADI 3112 ADI 3510, ADI 3999, ADI por omissao 3682, ADPF 130 e ADPF 144.
} 
Anencéfalo, ADPF 130/Lei de Imprensa (2009), ADI 4.578/ Lei da Ficha Limpa (2012), ADPF 186/Ações Afirmativas (2012). Em todos eles há uma enorme profusão de menções a precedentes estrangeiros e os dois últimos são bastante polêmicos e recentes.

$\mathrm{Na}$ maioria das vezes, o uso de precedentes estrangeiros nestes julgados foi feito de maneira assistemática e sem maiores justificativas. Nota-se também que os mesmos ministros que ora faziam um uso adequado, em outro julgado procediam a um uso sem qualquer justificativa.

Na realidade, das leituras efetuadas, apenas em dois julgados foi externada alguma preocupação acerca da utilização de precedentes estrangeiros por parte dos julgadores. No HC 84.424/Caso Ellwanger, que será adiante detalhado, o Ministro Moreira Alves asseverou:

Prosseguindo, Sr. Presidente, quero fazer algumas considerações sobre os preceitos colhidos no direito comparado, tendo eu reservas quanto á interpretação do direito nacional com base no direito estrangeiro, porquanto as tradições jurídicas, o raciocínio jurídico, o sistema jurídico e o ordenamento jurídico estão estreitamente vinculados com os aspectos culturais de um povo ${ }^{218}$.

Por sua vez, o Ministro Sepúlveda Pertence aduziu na ADI 2797/Improbidade Administrativa:

Sei bem do perigo da importação de doutrinas jurídicas e exemplos estrangeiros para o e no debate sobre o direito brasileiro. Tenho insistido em que não existe o direito, apenas os direitos. E o nosso direito é muito nosso, próprio a nossa cultura. A ponto de afirmarmos a necessidade de antropofagia jurídica à moda de Oswald de Andrade.

Estas foram as duas únicas objeções encontradas nos julgados lidos.

Feitas estas observações, será feita nos tópicos subsequentes a análise das cinco mencionadas decisões tendo em mente os modos e os critérios para utilização de precedentes estrangeiros explanados até aqui, prestando-se especial atenção se

\footnotetext{
${ }^{218}$ Página 15 da Confirmação de Voto.
} 
houve a demonstração de um algum elemento de conexão, se houve a contextualização da decisão, se foi feita uma justificativa para seu uso (finalidade/pertinência), se eventual consenso houve alguma influência, e, por fim, se a utilização incorreu em algum tipo de uso indesejado como os de submissão, repulsa, universal ou decorativo.

\subsection{O CASO ELLWANGER (HC 82.424)}

Trata-se de habeas corpus substitutivo de relatoria do Ministro Moreira Alves, impetrado por terceiros em favor de Siegfried Ellwanger, condenado por crime de racismo contra os judeus por publicar livro antissemita. A discussão posta girava em torno de três argumentos: a imprescritibilidade do crime de racismo, se os judeus eram ou não considerados uma raça e a amplitude da liberdade de expressão.

Seis ministros citaram precedentes estrangeiros ${ }^{219}$ em suas manifestações: Maurício Correia ${ }^{220}$, Moreira Alves $^{221}$, Gilmar Mendes ${ }^{222}$, Marco Aurélio ${ }^{223}$ e

\footnotetext{
219 O presente acórdão é extremamente longo (488 páginas) e vários precedentes estrangeiros são citados repetidamente pelos ministros. Assim, para evitar que a leitura ficasse cansativa e repetitiva, optou-se por uma análise e crítica global do julgado, apontando, quando necessário, algum ministro que tenha saído, de algum forma, do padrão constatado.

${ }^{220}$ Citou e descreveu sucintamente três casos: dois americanos - United States v. Lemrick Nelson e Shaare Tefila Congregation v. Cobb (481 U.S. 615 - 1987) - e um inglês - Mandla and another versus Dowell Lee and another. E concluiu: "Mostra-se, assim, que no direito comparado o problema da segregação racial é enfrentado atribuindo-se ao termo raça uma conotação mais complexa, sempre com o objetivo de assegurar o efetivo respeito aos postulados universais da igualdade e dignidade da pessoa humana"

${ }^{221}$ Primeiramente mencionou e explicou o caso Shaare Tefila Congregation v. Cobb (481 U.S. 615 - 1987). Em seguida, citou e explicou brevemente a decisão americana oriunda do caso RVA v. City of Saint Paul (05 U.S. 377 - 1992). Por fim, menciona outro caso, sem especificá-lo.

${ }^{222}$ Este ministro cita e sinteticamente analisa, em momentos distintos, os seguintes julgados estrangeiros: Shaare Tefila Congregation versus Cobb e Schenck v. United States, da Suprema Corte Americana; Mandla e outro versus Dowell Lee e outro, da Câmara dos Lordes Inglesa; Lehideux e Isorni v. França, Jersild v. Dinamarca e Roger Garaudy, todos da Corte Europeia de Direitos Humanos; e, ainda, o Caso Lebach, da Corte Constitucional Alemã. Ao final também mencionou decisões do Tribunal Constitucional Espanhol, de maneira indireta, por meio de doutrina. Citou a decisão STC 176/1995 a sentença 214/1991.

${ }^{223}$ O ministro Marco Aurélio cita inúmeros precedentes estrangeiros. Dos Estados Unidos: Miller v. California, Falwell v. Hustler Magazine Inc, New York Times v. Sullivan, Caso Terminello v. Chicago, Caso R.A.V v. City of St. Paul, Caso Texas v. Johnson. Da Alemanha: Caso Lüth (1958), Caso "Livro sobre a Guerra" (1994), Caso dos Soldados Assassinos (1995), Caso do "Romance Pornográfico” (1990). Da Espanha: Sentencia 176/1995.
} 
Celso de $\mathrm{Mello}^{224}$. Este acórdão é bastante farto no que concerne à citação de precedentes estrangeiros, pois uma infinidade deles é mencionada.

Em que pese o número de menções a precedentes estrangeiros variar de ministro para ministro e a estrutura diferente de cada voto, é perceptível que os julgados em sua maioria esmagadora foram utilizados no modelo decorativo e sem maiores preocupações em demonstrar qualquer elemento de ligação que justificasse o recurso ao precedente estrangeiro.

Observa-se também que, embora na grande maioria das vezes haja uma explicação sucinta sobre os precedentes citados, não há, por parte dos ministros, uma análise mais detida dos julgados alienígenas, o que significa dizer que as fases de contextualização e de análise de pertinência sugeridas por este trabalho não foram observadas.

Não se entende, por exemplo, porque os ministros Moreira Alves e Marco Aurélio recorreram à jurisprudência estrangeira, pois os julgados citados em nada interferiram com o resultado de suas opiniões.

O primeiro citou julgado afirmando que os judeus eram uma raça, mas entendeu, em sua conclusão, que o habeas corpus devia ser concedido justamente porque, no Brasil, os judeus não poderiam ser considerados uma raça, o que implicava na inocorrência do crime.

Já o segundo apresentou inúmeros precedentes que privilegiavam a liberdade de expressão e parecia indicar que a negação do holocausto era mera obra revisionista, o que implicaria na atipicidade do crime. Todavia, no final de seu voto, o ministro concedeu o habeas corpus, não por entender que o princípio da liberdade de expressão devesse prevalecer, mas por considerar prescrita a pretensão punitiva do Estado. Em outras palavras, além dos precedentes estrangeiros não serem contextualizados e devidamente comparados, eles sequer contribuíram para a conclusão do voto.

Também chama a atenção o excesso de menção a precedentes estrangeiros, em especial pelos ministros Gilmar Mendes e Marco Aurélio. Obviamente não há

\footnotetext{
${ }^{224}$ Recorre ao voto vencedor voto vencedor de Juiz Oliver Wendell Holmes Jr no caso norte-americano Schenck v. United States
} 
um número ideal que deve ser citado, mas é certo que o exagero apenas reforça a conclusão de que as citações são meramente ornamentais.

O mais curioso é que no meio desta profusão de citações, são mencionados precedentes que se contrariam e não há qualquer justificativa para isso. Sem contar que o excesso impede o leitor de aferir se e em que medida o material estrangeiro afetou a decisão de cada ministro.

Deve ser ainda que o ministro Gilmar Mendes, ao se referir à jurisprudência do Tribunal Constitucional Espanhol, o fez por meio de citação indireta (doutrina), o que deve ser evitado.

Por fim, deve se elogiar uma das citações de precedente estrangeiro realizada pelo ministro Celso de Mello. No final da confirmação de seu voto, o ministro cita o caso Virgínia v. Black et al., quando a Suprema Corte Americana decidiu que a liberdade de expressão, prevista na primeira emenda americana, não invalidava a lei penal que pune o delito tipificado como queimar uma cruz com a intenção de intimidar e agredir, pois queimá-la com este desiderato representa simbolicamente o ódio, sentimento este que deve ser repudiado pelo ordenamento.

O que resta claro nesta passagem é que Celso de Mello pretendeu demonstrar que mesmo a Corte Americana, conhecida por sua posição de apoio quase incondicional à liberdade de expressão, também permite a restrição a este valor, sendo lícito ao Estado punir algumas condutas que tenham finalidade criminosa.

O uso realizado por Celso de Mello foi bastante simples e sem maiores problemas. O recurso à decisão alienígena foi para demonstrar que mesmo países de cunho mais liberal, como os Estados Unidos, no qual a liberdade de expressão é quase um dogma, permitem a restrição à liberdade de expressão. Provavelmente, a menção aos Estados Unidos foi para rebater o temor que há no Brasil quanto a qualquer restrição a este princípio, ante o histórico ditatorial do país.

Feita esta análise, pode se asseverar que, exceto por uma citação feita pelo ministro Celso de Mello, que não ocorreu verdadeiro uso de precedentes estrangeiros neste julgado, uma vez que não houve a explicitação de qualquer elemento de conexão, bem como nenhuma preocupação em realizar a contextualização e a análise de 
pertinência. Em muitas passagens sequer é possível aferir qual a posição do ministro perante o julgado citado e também qual a influência do julgado estrangeiro sobre a decisão. Resta, de certa forma, a impressão de que as citações tinham por fim demonstrar erudição intelectual e não contribuir efetivamente para o julgado.

Por outro lado, além de se realizar o uso inadequado de precedentes estrangeiros, o Tribunal perdeu uma grande chance de estabelecer um intercâmbio mais produtivo com os julgados citados, pois muitos deles provavelmente tinham grande potencial para uma verdadeira interlocução constitucional.

\subsection{O CASO DO ABORTO DE FETO COM ANENCEFALIA (ADPF 54) - O VOTO DO MINISTRO GILMAR MENDES}

Também no julgamento da ADPF 54, que tratava da possibilidade da interrupção de gravidez em caso de feto anencéfalo (inconstitucionalidade de dispositivo do código penal que vedava o aborto nesta hipótese), houve, por parte do Ministro Gilmar Mendes, recurso ao uso de precedentes estrangeiros.

Em narrativa demasiada longa e desnecessária à conclusão de seu voto ele recorreu à utilização de precedentes estrangeiros para argumentar sobre a possibilidade de a jurisdição constitucional apreciar a constitucionalidade de leis préconstitucionais (no caso, o Código Penal). Neste ponto procedeu a uma explicação sobre como as Cortes Austríaca, Alemã, Italiana, Portuguesa e Espanhola lidavam com o assunto. Em nenhum momento foi realizada uma contextualização mais detalhada, resumindo-se o ministro a passar as conclusões normativas dos julgados.

Vale mencionar ainda que foram citados inúmeros julgados da Corte Constitucional de Viena apenas pelo seu número de registro, sem quaisquer esclarecimentos, e, ao citar a jurisprudência do Tribunal Constitucional Alemão, inacreditavelmente, foram repetidos os mesmos números. No tocante à Corte Italiana, invocou, indiretamente (via doutrina) um julgado de 1956. 
Ao final, apenas "analisando" a jurisprudência de 5 Cortes Constitucionais, conclui que todos os modernos tribunais constitucionais, exceto o da Áustria, buscam "assegurar sua competência para aferir a constitucionalidade das leis préconstitucionais em face da Constituição vigente".

Finalmente, após proceder ao estudo da jurisprudência do próprio Supremo Tribunal Federal, concluiu pela admissibilidade da arguição de preceito fundamental, pois a norma atacada havia passado a ser incompatível com a Constituição vigente.

Da leitura do voto do ministro Gilmar Mendes afere-se que (i) os precedentes invocados não foram contextualizados; (ii) que a partir da análise superficial (senão inexistente) da jurisprudência de 5 Cortes, chegou-se à conclusão de que os Tribunais Constitucionais modernos (todos) sempre realizam o controle de constitucionalidade de atos normativos pré-constitucionais, (iii) era possível alcançar a conclusão de que o ordenamento jurídico brasileiro permite o controle de constitucionalidade de atos anteriores à Carta da República sem a menção aos precedentes estrangeiros da maneira como foi feita.

Em outras palavras, o uso de precedentes estrangeiros neste caso foi meramente decorativo e sem qualquer justificativa ou interação. A leitura também indica que o ministro buscava um uso baseado em suposto consenso, ao asseverar que todos os modernos tribunais constitucionais, exceto o da Áustria, buscam "assegurar sua competência para aferir a constitucionalidade das leis pré-constitucionais em face da Constituição vigente". Todavia, o consenso não restou demonstrado.

\subsection{O CASO DA LEI DE IMPRENSA (ADPF 130)}

Cuida-se de discussão sobre a recepção constitucional da lei de imprensa, documento legislativo elaborado à época da ditadura cujo âmbito de aplicação era voltado para a regulação dos meios de comunicação. Analisou-se a constitucionalidade de seus instrumentos legais, como o direito de resposta e a responsabilização de veículos de imprensa. 
Buscava-se saber se os instrumentos previstos nesta lei ofendiam o disposto no art. $5^{\circ}$, incisos IV, V, IX, X e XIV, bem como os arts. 220 a 223, todos da Constituição Federal de 1988.

Dois foram os ministros que se utilizaram de precedentes estrangeiros: Gilmar Mendes e Celso de Mello.

\subsubsection{O voto de Gilmar Mendes}

Ao analisar a amplitude da liberdade de imprensa aduz o ministro:

A história de progressiva efetivação do valor da liberdade de imprensa se confunde com a própria história de definição jurisprudencial de seus limites pelas Cortes Constitucionais. O significado da liberdade de imprensa no Estado Democrático de Direito encontra-se na jurisprudência constitucional a respeito da definição dos limites à própria à própria liberdade de imprensa ${ }^{225}$. (p. 210)

Aponta o ministro que a "jurisprudência das cortes" produziu duas concepções sobre seu alcance.

Recorre, então, à $1^{\mathrm{a}}$ Emenda Americana, que positivou a liberdade de imprensa na constituição americana e aduz que duas vertentes emergiram de sua interpretação. A primeira, de viés liberal, foca na concepção de livre mercado de ideias e é baseada nos votos dissidentes de Oliver Wendell Holmes, no famoso caso Abrams. A segunda, de viés mais republicano, baseia-se na importância da imprensa como ambiente de deliberação pública e democrática é bem explicitada no voto de Louis D. Brandeis, no casos Whitney v. California e New York Co. v Sullivan. A citação, nesta passagem, é indireta, com informe da fonte (SUNSTEIN, Cass R., One case at a time. Judicial Minimalism on the Supreme Court. Cambridge: Harvard University, 1999, p. 176). Embora haja referência a duas vertentes, o ministro não esclarece o conteúdo dos julgados mencionados.

\footnotetext{
${ }^{225}$ Página 06 do voto.
} 
Em seguida, remete o leitor ao Tribunal Constitucional Alemão e sua jurisprudência, em especial ao famoso caso Lüth, que "construiu o conceito de dupla dimensão, duplo caráter ou dupla face dos direitos fundamentais, enfatizando, por um lado, o aspecto subjetivo ou individual, e, por outro, a noção objetiva ou caráter institucional das liberdades de expressão e de imprensa". Não houve, aqui, qualquer contextualização ou demonstração de pertinência. Não se sabe ao certo o motivo, mas talvez seja porque o ministro tomou o precedente alemão como familiar ao público brasileiro.

Ressalte-se que nenhum dos precedentes relacionados até o momento foi contextualizado ou detalhado. Não se sabe sequer qual o contexto fático do qual emergiram as questões constitucionais em discussão pelos Tribunais Americano e Alemão. Também se afere que as referências são indiretas, não havendo a leitura dos precedentes citados.

Passa, após citar julgados americanos e alemães, a analisar as duas tradições sobre a liberdade de expressão.

Primeiro frisa que a tradição americana, apenas na segunda década do século XX, passou a debater sobre as possíveis limitações à liberdade de imprensa. O ministro ressalta os históricos pronunciamentos de Oliver W. Holmes nos casos Schenck $v$. United States (249 US 47, 1919) e Abrams v. US (250 US 616, 1919). Cita, nesta oportunidade, um trecho do voto divergente de Holmes no caso Abrams sobre a noção de mercado de ideias. Todas as referências são indiretas, baseadas em livro de Cass Sunstein.

Sunstein chama essa "a primeira vertente sobre a concepção da liberdade de imprensa", que foi, inicialmente, posição vencida na Suprema Corte Americana em reiterados casos: Pierce v. United States (1920), Gitlow v. New York (1925), Whitney v. California (1927), sempre com votos dissidentes de Holmes, dpor uma ampla liberdade de imprensa, sem maiores restrições.

O ministro diz, então, que o mercado de ideias e sua capacidade de sempre fazer prevalecer a verdade são, talvez, a maior importância da liberdade de imprensa. O precedente é elemento indireto aqui.

Passa, então, a falar de uma virada jurisprudencial nos E.U.A., com uma breve explicação sobre ela. Citou primeiramente o caso New York Co v. Sullivan. 
Nesta oportunidade a Suprema Corte Americana afirmou que a verdadeira liberdade de imprensa apenas seria garantida se dos comunicadores não fosse exigida a necessidade de provar a verdade das notícias críticas sobre os funcionários públicos. Pensamento contrário impediria a liberdade de informação, tão cara à democracia. Este entendimento foi posteriormente aplicado em outros casos, como Curtis Publising Co. v. Butts e Associated Press v. Nalker (figuras públicas que não estavam desempenhando função pública) e, ainda, em Rosenbloom v. Metromedia (ausência de figura pública mas em assuntos de transcendência pública).

Conclui o ministro asseverando que a liberdade de expressão é vista como elemento fundamental do sistema de deliberação pública e democrática nos Estados Unidos. Tal perspectiva impede ou é contrária a maiores intervenções estatais neste campo.

Ao final, o ministro aduz que o art. 220 da CF/88 "contém cláusula proibitiva de qualquer restrição às liberdades de expressão e de imprensa. Ao mesmo tempo em que prescrevem a não restrição dessas liberdades, esses textos não apenas permitem, como obrigam a intervenção legislativa no sentido de sua promoção efetividade ${ }^{, 226}$. Ele aduz, ainda, que as duas vertentes são um aparente paradoxo que circunda a liberdade de expressão, os quais são conciliados pelas Cortes Constitucionais que entendem que "as restrições legislativas são permitidas e até exigidas constitucionalmente quando tem dever de proteger, garantir e efetivar tais liberdades".

No tocante ao Tribunal Constitucional Alemão, este chegou à mesma conclusão ao analisar o art. $5^{\circ}$ da Grundgezetz, enxergando na liberdade de imprensa uma dupla dimensão (subjetiva e objetiva), qual seja, um direito subjetivo fundamental e uma garantia institucional.

Recorre, então, ao caso Lüth e cita passagens desta decisão. Depois menciona o caso Spiegel (BVerfGE 20, 62, 1966), transcrevendo passagens do julgado.

\footnotetext{
${ }^{226}$ Página 13 do voto.
} 
Vale observar que em nenhum momento é explicado ao leitor a história do caso, o que estava realmente em jogo (contextualização).

O que resta nítido, de qualquer forma, é que o ministro utilizouse de precedentes estrangeiros para demonstrar o duplo aspecto da liberdade de expressão. Para isso, recorreu à Suprema Corte Norte-Americana e ao Tribunal Constitucional Alemão. No entanto, o excesso de citações torna difícil de se compreender as relações entre os julgados estrangeiros e o caso doméstico.

Posteriormente, passa a analisar o panorama normativo brasileiro e frisa que não há expressa previsão de limitação legal à liberdade de imprensa. Mas conclui que

o texto constitucional não exclui a possibilidade de que se introduzam limitações à liberdade de expressão e de comunicação, estabelecendo expressamente, que o exercício dessas liberdades há de se fazer com observância do disposto na constituição. Não poderia ser outra a orientação do constituinte, pois, do contrário, outros valores, igualmente relevantes, quedariam esvaziados diante de um direito avassalador, absoluto e insuscetível de restriçãa ${ }^{227}$.

E Continua:

tem-se, pois, aqui, autorização expressa a reserva legal qualificada que autoriza o estabelecimento de restrição à liberdade de imprensa com vistas a preservar outros direitos individuais, não menos significativos, como direitos da personalidade em geral ${ }^{228}$.

Cita o caso do Romance Mephisto, de Klaus Mann, que se iniciou na Corte Estadual de Hamburgo e foi parar no Tribunal Constitucional Alemão. Explicou as premissas fáticas e transcreveu o acórdão. Tratava-se de um caso em que uma editora alemã publicara um livro poético-artístico, com supostas imputações injuriosas a um falecido teatrólogo. Seu filho, inconformado, recorreu à Justiça. Haveria um embate entre direito da personalidade e a liberdade artística. Ao final, o Tribunal Constitucional Alemão

\footnotetext{
${ }^{227}$ Página 23 do voto.

${ }^{228}$ Página 24 do voto.
} 
entendeu que, neste caso, deve prevalecer a dignidade da pessoa humana e não a liberdade artística.

Arrematando, o ministro aponta que o texto constitucional brasileiro, como o alemão, no caso da liberdade de imprensa, não apresenta restrição, mas isto não significa que ela não possa existir, mas que ela é imanente.

Note-se que o uso do precedente estrangeiro neste ponto foi feito de maneira adequada, pois houve uma apresentação do caso estrangeiro, uma descrição do litígio, uma contextualização, para, ao final, o ministro apontar a semelhança entre os ordenamentos brasileiro e alemão. Buscava o ministro demonstrar que outro Estado, também em situação similar, também era possível extrair eventuais limitações à liberdade de expressão decorrentes do próprio texto constitucional.

Após, o ministro voltou-se para o caso alemão Lebach (BverfGE 35, 2002) o qual foi adequadamente descrito. Mais um conflito entre a liberdade de expressão e imprensa com direitos da personalidade. Transcreve, nesta oportunidade, a síntese do acórdão, concluindo:

Faço essas análises, buscando lições do direito comparado, para concluir que a ordem constitucional de 1988 abre espaço para uma lei de imprensa instituída para proteger outros princípios constitucionais, especialmente os direitos à honra e à privacidade, enfim, à dignidade da pessoa humana, assim como para a proteção da própria atividade jornalística e de comunicação geral.

Ressalto neste ponto, que é extremamente falacioso o argumento, não raras vezes utilizado, de que, em países de democracia desenvolvida, não há leis de imprensa ou de regulação da atividade da imprensa.

Fiz uma breve pesquisa sobre o assunto no direito comparado e apresento a seguir, de forma sucinta o resultado da pesquisa sobre a presença das leis de imprensa nos diversos ordenamentos jurídicos ${ }^{229}$.

São, então, apresentadas as legislações de Espanha, Portugal, México, Reino Unido, França, Chile, Peru, Uruguai e Alemanha. Ao final ele conclui:

\footnotetext{
${ }^{229}$ Página 31 do voto.
} 
Como se vê nesse breve relato de imprensa ou as lei reguladoras dos meios de comunicação de maneira alguma são incompatíveis com a democracia ou com o Estado Democrático de Direito. Nossa ordem constitucional, instituída em 1988, permite, sim, a regulação da imprensa, e isso vem da interpretação do próprio art. 220 da Constituição ${ }^{230}$.

Ao final vota pela recepção parcial referente ao direito de resposta, adequados aos valores constitucionais vigentes.

Embora a última parte do voto se refira à legislação estrangeira e não a precedentes estrangeiros propriamente ditos, sua análise tem valor para o presente estudo. Ademais de se considerar que se elas estão em pleno vigor e não foram declaradas constitucionais, significa que o Tribunal Constitucional de cada ordenamento estudado concorda com seu conteúdo.

A argumentação desenvolvida pelo ministro Gilmar Mendes nesta parte do volto foi simplesmente exemplar. Ele procedeu a um estudo detalhado da legislação de cada país sobre a regulação da liberdade de imprensa, não se restringiu apenas a países considerados de primeiro mundo, mas, também, a países latinos, com histórico ditatorial como o brasileiro e, ao final, deixou claro seu desiderato, que era mostrar que a regulação à imprensa não ofende, necessariamente, a democracia.

Indubitavelmente, ele contextualizou o tema, recorreu a países que servem de modelo para o Brasil, bem como a países com histórico similar ao brasileiro, demonstrando a finalidade de se recorrer ao precedente estrangeiro. $\mathrm{O}$ uso, aqui, foi, de certa forma, dialógico e pragmático. Dialógico na medida em que foi possível melhor compreender o sistema jurídico brasileiro com o uso de elemento do direito estrangeiro. Pragmático porque buscava demonstrar que uma regulação adequada da liberdade de imprensa não acarretaria danos ao princípio da liberdade de expressão.

Por fim, uma única observação deve ser feita em relação ao uso dos precedentes americanos. Mais adiante, no aditamento de voto do Ministro Carlos Britto, este indaga o ministro Gilmar Mendes se ele havia lido os julgados citados. Mendes negar ter

\footnotetext{
${ }^{230}$ Página 45 do voto.
} 
lido os julgados, aduzindo que as citações foram indiretas. Como já apontado, o uso de precedentes estrangeiros de maneira indireta deve ser evitado, como forma de se prevenir eventuais distorções do teor da decisão analisada.

\subsubsection{O voto de Celso de Mello}

O ministro Celso de Mello defende a não recepção da lei de imprensa. Para fundamentar seu voto, cita, entre outros argumentos, a jurisprudência estrangeira:

Não foi por outra razão que o Tribunal Constitucional espanhol, ao proferir as sentenças $n^{\circ}$ 6/1981 (Rel. Juiz Francisco Rubio Llorente), $\mathrm{n}^{\circ}$ 12/1982 (Relator Luis Díez-Picazo), $\mathrm{n}^{\circ}$ 104/1986 (Rel. Juiz |Francisco Tomás y Valente) e n 171/1990 (Rel. Juiz Bravo-Ferrer), pôs em destaque a necessidade essencial de preservar-se a prática da liberdade de informação, inclusive o direito de crítica que dela emana, como um dos suportes axiológicos que informam e que conferem legitimação material à própria concepção de regime democrático.

É relevante observar, aqui, que o Tribunal Europeu de Direitos Humanos (TEDH), em mais de uma ocasião, também advertiu que a limitação do direito a informação e do direito (dever) de informar, mediante (inadmissível) redução de sua prática 'ao relato puro, objetivo e asséptico de fatos, não se mostra constitucionalmente aceitável nem compatível com o pluralismo, a tolerância (...), sem os quais não há sociedade democrática (...) (Caso Handyside, Sentença do TEDH, de 07/12/1976).

Essa mesma Corte Europeia de Direitos Humanos, quando do julgamento do Caso Lingens (Sentença de 08/07/1986), após assinalar que a 'divergência subjetiva de opiniões compõe a estrutura mesma do aspecto institucional do direito à informação', acentua que 'a imprensa tem a incumbência, por ser essa a sua missão, de publicar informações e ideias sobre as questões que se discutem no terreno político e em outros setores de interesse público (...)', vindo a concluir em tal 
decisão, não ser aceitável a visão daqueles que pretendem negar, à imprensa, o direito de interpretar as informações e de expender as críticas pertinentes ${ }^{231}$.

Posteriormente, o ministro, ao explanar acerca da importância da liberdade de expressão para a democracia, faz uma citação indireta de precedente estrangeiro:

Vale registrar, por relevante, fragmento expressivo da obra do ilustre magistrado federal SÉRGIO FERNANDO MORO ('Jurisdição Constitucional como Democracia, p. 48, item n ${ }^{\circ}$ 1.1.5.5, 2004, RT), no qual põe em destaque um 'landmark ruling' da Suprema Corte norteamericana, proferida no caso New York Times v. Sullivan (1964), a propósito do tratamento que esse Alto Tribunal dispensa à garantia constitucional da liberdade de expressão:

'A Corte entendeu que a liberdade de expressão em assuntos públicos deveria de todo modo ser preservada. Estabeleceu que a conduta do jornal estava protegida pela liberdade de expressão, salvo se provado que a matéria falsa tinha sido publicada maliciosamente ou com desconsideração negligente em relação à verdade. Diz o voto do condutor do Juiz William Brennan:

(...) o debate de assuntos públicos deve ser sem inibições, robusto, amplo, e pode incluir ataques veementes, cáusticos e, algumas vezes desagradáveis ao governo e às autoridades governamentais, ${ }^{232}$.

Em outra passagem, ao aduzir que, embora fundamental para a democracia e constitucionalmente garantida, a liberdade de imprensa pode ser regulada em função de outros valores também constitucionais, o ministro realiza nova citação de precedente estrangeiro:

Daí a advertência do juiz Oliver Wendell Holmes Júnior, proferida em voto memorável, em 1919, no julgamento do caso Schenck v. United States (249 U.S. 47, 52), quando, ao pronunciar-se sobre o caráter relativo da liberdade de expressão tal como protegida pela Primeira

\footnotetext{
${ }^{231}$ Página 08 do voto.

${ }^{232}$ Página 13 do voto.
} 
Emenda à Constituição dos Estados Unidos da América, acentuou que 'A mais rígida proteção à liberdade de palavra não protegeria um homem que falsamente gritasse fogo num teatro e assim, causasse pânico', concluindo, com absoluta exatidão, em lição inteiramente aplicável ao caso que, a 'questão em cada caso é saber se as palavras foram usadas em tais circunstâncias e são de tal natureza que envolvem perigo evidente e atual (clear and presente danger) de se produzirem os males gravíssimos que o Congresso tem o direito de prevenir. É uma questão de proximidade e grau'.

É curioso notar que a passagem acima transcrita é cópia de um parágrafo inserido no voto do mesmo ministro no Caso Ellwanger, analisado no item 4.2., indício de que a citação foi meramente retórica, ou melhor, decorativa.

Com efeito, as decisões mencionadas, ademais das referências indiretas, não foram contextualizadas ou descritas. Não se depreende exatamente qual a relação delas com o caso sob análise, ou seja, não se sabe até que ponto os dispositivos da lei de imprensa eram comparáveis com os litígios que deram origem aos precedentes estrangeiros citados.

Não bastasse isso, não houve qualquer justificativa para o fato de se recorrer à jurisprudência dos Estados Unidos, país com forte tradição liberal, onde a liberdade de expressão é bastante protegida.

\subsection{A LEI DA FICHA LIMPA (ADI 4.578)}

Tratava-se de ação direta de constitucionalidade que questionava a constitucionalidade da Lei Complementar $n^{\circ} 135 / 10$, que previa uma série de causas de inelegibilidade baseadas em condenação por órgão colegiado, sem, no entanto, o trânsito em julgado da condenação. Em suma, haveria um suposto confronto entre os direitos políticos e o princípio da presunção de inocência.

Três ministros recorreram a material estrangeiro: Dias Toffoli, Rosa Weber e Gilmar Mendes 


\subsubsection{O voto de Dias Toffoli}

Em seu voto o ministro aponta que inelegibilidade decorrente de mera condenação por órgão colegiado não tem o condão de impedir a candidatura do cidadão, pois tal entendimento ofenderia o princípio da presunção de inocência (art. $5^{\circ}$, LVII, CF/88).

Para ele, a presunção de inocência não vale apenas na seara penal, mas é aplicável a todos as outras áreas do direito. Para reforçar sua posição, recorre a precedentes espanhóis:

Em termos de Direito Comparado, note-se que o Tribunal Constitucional da Espanha desenvolveu fortemente sua jurisprudência no sentido de que o conteúdo essencial do direito fundamental à presunção de inocência radica-se na situação jurídica de um indivíduo até o momento em que uma sentença, pronunciada por um tribunal legal e independente no âmbito de um processo no qual se conservam todas as garantias constitucionais, condena o processado em relação a um ou vários delitos concretos. (PÉREZ-PEDRERO, Enrique Belda. La presunción de inocencia. Parlamento y Constitución. Anuario, $\mathrm{n}^{\circ} 5$, 2001, p. 180). (p. 84)

\section{(...)}

Nesse aspecto, como teve a oportunidade de decidir o Tribunal Constitucional da Espanha, a sanção proveniente dos órgãos públicos, seja de caráter judicial, seja de caráter administrativo, aplicada em decorrência de sentença ou ato administrativo equivalente, '(...) não pode suscitar nenhuma dúvida de que a presunção de inocência rege, sem exceções, o ordenamento sancionador e já de ser respeitada na imposição de quaisquer sanções, sejam penais, sejam administrativas (...)' ( $8^{\mathrm{a}}$ Sala do Tribunal Constitucional 76/90, caso Ley General Tributaria). (p.85)

Curioso notar, primeiramente, que a citação foi indireta, ou seja, não houve a análise do precedente estrangeiro citado. 
Em segundo lugar, não houve qualquer explicação acerca dos casos citados, dos elementos que poderiam conectar o ordenamento brasileiro com o espanhol ou mesmo da finalidade da citação. Ao que parece, foi uma utilização ornamental.

Por fim, o que salta aos olhos, neste caso, é a utilização de precedentes espanhóis de maneira seletiva e desconsiderando a posição do Tribunal Constitucional Espanhol sobre o princípio de presunção da inocência. O ministro sequer se deu ao trabalho de fazer uma análise mais detida do direito espanhol sobre o princípio em apreço e acabou por apresentar entendimento equivocado do Tribunal Espanhol sobre o assunto em comento.

Diferentemente do aduzido, na Espanha, o princípio da presunção de inocência não tem a amplitude sugerida pelo ministro. Pelo contrário, na Espanha, qualquer pessoa condenada em primeira instância pode começar a cumprir a pena provisoriamente. Nesse país, o princípio da presunção de inocência é alcançado quando são observados os princípios do contraditório e da ampla defesa ${ }^{233}$.

O equívoco, aqui, é gravíssimo, pois além de proceder a uma analise inadequada, o ministro faz afirmações não consentâneas com o ordenamento jurídico da Espanha, para afastar a constitucionalidade de uma lei aprovada democraticamente. Muito provavelmente a falha se deu por não proceder à devida contextualização da comparação, o que neste caso significaria verificar não apenas um julgado espanhol, mas sim vários e assim poder aferir a posição espanhola sobre o assunto.

\footnotetext{
${ }^{233}$ Explicam Luiza Cristina Fonseca FRISCHEISEN, Mônica Nicida GARCIA e Fábio GUSMAN em artigo denominado "Execução Provisória da Pena - Panorama nos ordenamentos nacional e estrangeiro" (disponível em http://2ccr.pgr.mpf.gov.br/coordenacao/eventos/execucao-da-

pena/3_execucao_provisoria_da_pena_versao_final_corrigido2.pdf.): “A presunção da inocência está expressa na Constituição Espanhola de 1978 no n. 2 do art. 24, no título de direitos e deveres fundamentais. A Espanha é outro dos países em que, muito embora seja a presunção de inocência um direito constitucionalmente garantido, vigora o princípio da efetividade das decisões condenatórias. Seguindo este princípio, se o acusado foi condenado em processo em que lhe foi oferecido contraditório e ampla defesa, em que foram cotejadas todas as provas, observado está o princípio da presunção da inocência. A sentença condenatória é, deste modo, plenamente executável, mesmo que outros recursos estejam em trâmite. Assim já se pronunciou o Tribunal Constitucional espanhol: "sin merma del equivocado enfoque en que se mueve el recurrente -constreñido a la presunción de inocencia-, la efectividad de las sanciones, no entra en colisión con la presunción de inocencia; la propia legitimidad de la potestad sancionatoria, y la sujeción a un procedimiento contradictorio, abierto al juego de la prueba según las pertinentes reglas al respecto, excluye toda idea en confrontación con la presunción de inocencia." Ressalte-se, ainda que o artigo 983, do Código de Processo Penal Espanhol admite até mesmo a possibilidade da continuação da prisão daquele que foi absolvido em instância inferior e contra o qual tramita recurso com efeito suspensivo em instância superior" (pp.. 23-24).
} 


\subsubsection{O voto de Rosa Weber}

Ao abordar a importância moralizante da lei da ficha limpa e apontar que o Supremo Tribunal Federal é uma corte contramajoritária, mas que, ao mesmo tempo, deve ouvir a voz da população, Rosa Weber acentua que a Corte deve estar aberta para todas as interpretações para alcançar a melhor delas. Então aduz:

É sempre oportuno lembrar que 'nós não damos a última palavra porque somos infalíveis, mas nós somos infalíveis somente porque damos a última palavra. (Brown v. Allen, 344 US, 443, 540 - 1953).

Embora cite um precedente estrangeiro, a passagem acima transcrita não pode ser considerada utilização de precedente estrangeiro, pois visava apenas ilustrar o peso e a importância do controle de constitucionalidade.

No tocante ao princípio da presunção de inocência, Rosa Weber apresenta seu histórico e, para isso, recorre aos artigos de Barbara J Shapiro, que escreveu "Beyond reasonable doubt and problable cause: Historical perspectives on de AngloAmerican Law of Evidence" e de James Whitman, com seu trabalho chamado "The origins of reasonable doubt: Theological roots of the criminal trial". Por meio destes estudos cita, indiretamente, uma série de decisões estrangeiras que mencionaram o princípio em tela:

Já em julgamentos do final do século dezoito, tal standard probatório pode ser encontrado em julgamentos na Inglaterra e nas então colônias norte-americanas. Nos julgamentos do Massacre de Boston de 1770, a Acusação invocou a fórmula. Em 1777, o standard teria sido utilizado pela Defesa em julgamento no Tribunal de Old Bailey, em Londres. Em julgamentos havidos entre 1783 a 1786 no mundo anglo-saxão, podem ser encontradas nas instruções dirigidas aos jurados diversas referências ao standard, assim como no julgamento de Weedom (1795), de Glennan (1796), no julgamento de 1798 de Matthew Lyon por sedição no Circuito do Distrito de Vermont e ainda no julgamento dos 'Insurgentes de Northampton' perante a Corte do Circuito Federal, em 1799 a 1800, e assim cada vez mais frequentemente. (p. 157)

O intuito aqui não foi adotar ou recusar os precedentes estrangeiros, mas apenas ilustrar o panorama histórico da aplicação do princípio. 
Narra ela que o princípio da presunção de inocência tem forte ligação com a questão probatória, o que, na realidade, significa que ele é um princípio que veda restrições desnecessárias aos direitos do acusado até o julgamento final.

Para a ministra, a presunção de inocência é extensível a outros campos do direito que não só o criminal. Contudo, não tem a mesma força. Ele deixa de ser quase absoluto ao sair da esfera penal. Ela aduz, ainda, que, se no próprio direito penal há exceção ao princípio, com as prisões provisórias ou cautelares, não parece absurdo que a presunção de inocência tenha outras restrições nas demais áreas do direito. Em outras palavras, mesmo na seara penal é possível a prisão antes do trânsito em julgado.

Então, a ministra recorre ao direito comparado, buscando referências no direito americano e francês. Justifica sua seleção aduzindo que ambos são países ocidentais, berços do princípio em apreço, mas com tradições jurídicas distintas. E começa afirmando que em ambos os países a presunção de inocência não significa a impossibilidade de prisão após o primeiro julgamento.

Esclarece a ministra que nos Estados Unidos, após o julgamento e na fase recursal, a regra é a prisão e não a liberdade (Seção 3.143, "b”, do Título 18 do Código Penal Federal dos Estados Unidos).

Na França, por sua vez,

...a condenação pela Cour d' Assises, competente para julgar crimes em primeira instância, importa na manutenção do condenado na prisão ou em sua colocação na prisão mesmo durante a fase de apelação, salvo exceções específicas, conforme previsão do artigo 367 do Code de Procédure Pénale francês, com a redação da Lei 2000-516, de 15.06.2000

Cita doutrina francesa e, por fim, decisão da Corte Francesa de Cassação que considerou a legislação mencionada compatível com o princípio da presunção de inocência:

E afastando qualquer dúvida sobre o sistema francês, a Corte de Cassação da França já teve oportunidade de decidir pela compatibilidade do referido artigo 367 com o princípio da presunção 
de inocência: 'Cour d' Assises - Prisão preventiva - Ordem de prisão - Execução - Artigo 367, alínea 2, do Código de Processo Penal com a redação da Lei de 15 de junho de 2000. Não é contrário ao princípio da presunção de inocência que, como prevê o artigo 367, alínea 2, do Código de Processo Penal, com a redação da Lei de 15 de junho de 2000, a ordem de prisão seja colocada em execução ou que continue a produzir os seus efeitos até que a duração da detenção seja aquela da pena cominada enquanto o aresto não é definitivo e, ante o caso, durante a instância de apelo.' (Cour de Cassation, Chambre criminelle, du 20 juin 2001, 01-82.926, Bulletin criminel 2001 n. ${ }^{\circ} 154$ p. 483) (...) Em síntese, antes do julgamento, os sistemas norte-americano e francês são semelhantes ao nosso, respondendo o processado, em regra, em liberdade, mas, após o julgamento, mesmo de primeira instância, a prisão é imediata como regra e a manutenção do condenado em liberdade, na fase de apelo, é a exceção ${ }^{234}$.

Ao final, ela conclui:

Peço escusas por essas digressões sobre o princípio da presunção de inocência, mas são elas necessárias para estabelecer as premissas que igualmente norteiam o meu voto no presente caso: i) o princípio da presunção de inocência está relacionado com a questão probatória, ii) o princípio da presunção de inocência também impede a imposição de restrições aos direitos do processado antes de um julgamento, mas não tem nessa vertente caráter absoluto, sendo elas admitidas desde que necessárias, iii) o princípio da presunção de inocência não é universalmente compreendido como perdurando até o trânsito em julgado, antes, na tradição de países que constituem o seu próprio berço histórico, perde força após um primeiro julgamento, ainda que não definitivo e iv) o princípio da presunção de inocência é pertinente ao Processo Penal.

Apresentadas tais premissas, repiso minha compreensão de que o princípio constitucional em apreço irradia seus efeitos para outros

\footnotetext{
${ }^{234}$ Páginas $18-19$ do voto.
} 
ramos do Direito, como amplamente reconhecido por esta Corte no julgamento da ADPF n. 144 (Rel. Min. Celso Mello - por maioria - j. 06.8.2008 - Dje 35, de 26.02.2010), dentre os quais o Eleitoral, comportando, porém, restrições ${ }^{235}$. (pp.. 163-164)

O uso realizado pela ministra Rosa Weber pode, certamente, ser considerado adequado. Embora a pesquisa pudesse ter se voltado para a situação em discussão no caso brasileiro (impossibilidade de se candidatar a cargo eletivo por condenação em órgão colegiado sem trânsito em julgado), ela justificou a escolha do direito/precedente estrangeiro, apontando que seu objetivo era simplesmente demonstrar que o princípio da presunção de inocência não era, nem nos países que o inventaram, tão absoluto, sequer na esfera penal.

Ela se propôs e conseguiu demonstrar, por meio de utilização de direito estrangeiro, quão razoável era que pessoas condenadas por órgãos colegiados não pudessem se candidatar a cargos públicos. E isto foi feito mostrando que democracias liberais e consolidadas tinham uma visão muito menos ampla do princípio da presunção de inocência na própria esfera criminal do que o Brasil.

\subsubsection{O voto de Gilmar Mendes}

No tópico intitulado "II - Violação ao princípio da presunção de não culpabilidade”, o ministro faz um histórico sobre o aludido princípio e afirma que este direito, embora já existente e de origem iluminista, foi consagrado na Declaração de Direitos do Bom Povo da Virgínia.

Afirma ele que o princípio da presunção de inocência é a antítese do totalitarismo e da autocracia, uma conquista democrática inestimável. Para ele, o princípio constitucional em comento é inafastável até o trânsito em julgado da sentença condenatória. Assevera, ainda, que o princípio da presunção de inocência "não se esvazia progressivamente à medida em se sucedem os graus de jurisdição" ${ }^{236}$ (p. 275). Também assevera que ele não tem aplicação apenas na esfera penal.

\footnotetext{
${ }^{235}$ Páginas 19-20 do voto.

${ }^{236}$ Página 15 do voto.
} 
Posteriormente, passa o ministro a atacar a posição externada no voto do Relator Luiz Fux, sobre a assertiva de que o fato da lei complementar contestada ser oriunda de iniciativa popular deveria ser olhado com cuidado pelo Supremo Tribunal Federal. Para Mendes, a iniciativa popular de maneira algum diminuiria o papel contramajoritário do Tribunal Constitucional. Com base no trabalho de Eugene Rosto, apresentado na conferência ocorrida no The Club, em New Haven y The Yale Law School Alumni Association of Boston (1953), passa, então a apontar a importância do papel contramajoritário da Suprema Corte.

Com base neste trabalho, passa a citar, indiretamente, decisões não especificadas da Suprema Corte Americana, que estariam pautando a conduta da polícia. Divaga sobre a importância das decisões contramajoritárias, sem, no entanto, enfrentar algum precedente específico ou demonstrar como eles lidaram com o princípio em comento.

Curioso notar que o ministro Gilmar Mendes, um dos que mais recorre à citação de precedentes estrangeiros em seus votos, não menciona como qualquer país lida com o assunto, seja na esfera penal, seja nas demais áreas do direito. A maioria dos países europeus, bem como os próprio Estados Unidos, entendem que o princípio da presunção de inocência, mesmo na esfera penal, tem um alcance menor do que aquele defendido pelo Supremo Tribunal Federal.

Ademais, também não deixa de chamar atenção o fato de ele citar a Declaração de Direitos do Bom Povo da Virgínia e não se preocupar em analisar como os Estados Unidos, país de origem do aludido documento, encaram o princípio em comento.

No caso deste voto específico, a pergunta que surge é justamente o porquê do silêncio em relação a alguns países tão citados pelo ministro, como Alemanha e Estados Unidos. Tem-se, aqui, uma situação curiosa, aquela em que alguns precedentes estrangeiros poderiam ser analisados, ainda que para serem refutados, mas que o julgador, por motivo desconhecido, optou por ignorá-los. 
4.6 O CASO DAS COTAS (RESERVAS DE VAGAS) PARA AS UNIVERSIDADES PÚBLICAS $(A D P F 186)^{237}$ - O VOTO DO RELATOR MINISTRO RICARDO LEWANDOWSKI

Cuida-se de arguição de descumprimento de preceito fundamental, de relatoria do ministro Ricardo Lewandowski, na qual se discutiu a constitucionalidade da reserva de vagas nas universidades públicas federais com base no critério étnico-racial frente ao princípio constitucional da igualdade. Na elaboração dos fundamentos da decisão unânime do órgão pleno do Supremo Tribunal Federal, o relator recorreu a jurisprudência estrangeira em parte para segui-la e em parte para refutá-la.

Em seu voto, o relator inicialmente reconhece que o sistema de cotas não tem origem norte-americana, mas, sim, indiana. Nesta oportunidade, faz um relato histórico sobre o surgimento das cotas na sociedade indiana. Inclusive chega a mencionar que na constituição indiana há dispositivo explícito autorizando a utilização da política de cotas em várias esferas da vida pública indiana, inclusive no Poder Legislativo.

Todavia, embora faça uma análise histórica do sistema de cotas no ordenamento jurídico indiano, o relator não faz qualquer menção à jurisprudência daquele país, que apresenta uma grande desigualdade social e uma constituição extensa e programática como a brasileira. Ante tais características uma interlocução com a jurisprudência indiana poderia ser bastante proveitosa.

Veja-se, por exemplo, a teoria do "creamy layer" ("camada cremosa") desenvolvida pela Suprema Corte Indiana no tocante ao tema das ações afirmativas. De acordo com o entendimento do Tribunal Indiano ${ }^{238}$, aqueles que fazem parte da "creamy layer" não podem se beneficiar das políticas de cotas, isto é, aqueles pertencentes a determinadas castas beneficiadas pelas políticas de cotas, mas que são, por exemplo, filhos de médicos, empresários, altos funcionários públicos, ou têm origem em famílias com alta renda, não podem se utilizar das cotas. Tal teoria foi desenvolvida justamente para evitar que o

\footnotetext{
${ }^{237}$ Até a presente data o acórdão e os fundamentos deste caso não foram publicados. A presente análise foi feita com base no rascunho do voto do relator, que foi unanimemente acompanhado pelo órgão pleno do Supremo Tribunal Federal e disponibilizado pelo próprio site do tribunal.

${ }^{238}$ Vide, por exemplo, os casos Sawhney \& Ors v. Union of India (1993 SCC 477) e Unni Krishnan, J.P. \& Ors. Vs. State of Andhra Pradesh \& Ors (1993 SCC 645).
} 
sistema de cotas indiano se desvirtuasse e atendesse as necessidades daqueles que justamente não precisam das vantagens propiciada pelo sistema de cotas.

Do ponto de vista deste trabalho, o julgado brasileiro perdeu uma grande oportunidade de aprender com a experiência indiana sobre o assunto, especialmente porque o próprio relator reconheceu em seu voto a origem indiana do instituto das cotas raciais e, principalmente, pelo fato de tanto o Brasil, como Índia, em que pese às diferenças culturais, sejam democracias jovens que tentam, de alguma maneira, transformar em realidade as promessas constitucionais de igualdade social.

Continuando seu voto, após uma longa digressão sobre a ordem constitucional brasileira, o relator recorre a três casos da Suprema Corte Norte-Americana: Bakke v. Regents of the University of California (1978), Gratz v. Bollinger (2003) e Grutter v. Bollinger (2003), abrindo, inclusive, um tópico para abordar a jurisprudência americana. Nesta oportunidade chega a mencionar o teste "narrowly taylored", criado pela Corte Americana, mas não explica o que seja.

Faz uma descrição detalhada do caso Grutter v. Bollinger e afirma que o julgado manteve a decisão do caso Bakke no qual restou decidido que a raça poderia ser considerada um elemento na política de admissão para as instituições do ensino superior. As universidades foram, assim, autorizadas a usar o critério raça para suas seleções.

De acordo com o ministro, posteriormente, Barbara Grutter ajuizou uma ação contra a Universidade de Michigan afirmando que haveria sofrido discriminação por ser branca, pois mesmo com notas relativamente altas não conseguiu vaga na universidade. O juiz de primeira instância considerou a seleção da Universidade inconstitucional. O tribunal de apelação reformou, citando o caso Bakke para autorizar o uso do critério racial.

Barbara Grutter recorreu, então, à Suprema Corte Americana e, desta forma, pela terceira vez, um caso envolvendo a constitucionalidade das ações afirmativas chegou à mais alta corte americana, a qual, mais uma vez, confirmou a constitucionalidade das ações afirmativas. Nesta oportunidade o relator transcreve parte do voto vencedor:

Como parte de seus objetivos de 'reunir uma turma que seja ao mesmo tempo excepcionalmente qualificada, do ponto de vista acadêmico, e 
amplamente diversificada' a Escola de Direito procura 'matricular uma massa crítica de estudantes que provém de minorias'.

(...). O interesse da Escola de Direito não é simplesmente 'assegurar que seu corpo discente seja integrado por um determinado porcentual de membros de um grupo específico meramente em razão de sua raça ou etnia (...). Ao revés, o conceito de 'massa crítica' da Escola de Direito é definido em face dos benefícios educacionais que a diversidade pode produzir'.

Esses benefícios são substanciais. Como o juiz da Corte Distrital enfatizou, a política de admissão da Escola de Direito promove 'compreensão [interracial]', ajuda a romper com os estereótipos raciais e 'permite que os estudantes aceitem melhor as pessoas de raças diferentes. (...)'. Esses benefícios são importantes e louváveis, porquanto 'a discussão em sala de aula é tanto mais viva, inspirada, esclarecida e interessante' quanto 'mais diversificados forem os seus estudantes'.

Universidades (...) representam o local de treinamento de um grande número de nossos líderes (...). A fim de conferir legitimidade a nossos líderes aos olhos da comunidade, é necessário que o caminho para a liderança seja visivelmente aberto a indivíduos qualificados e talentosos de todas as raças e etnias. Todos os membros de nossa sociedade heterogênea devem ter confiança na abertura e integridade das instituições de ensino que fornecem esse treinamento (...). O acesso (...) à educação (...) deve estar aberto a indivíduos talentosos e qualificados de todas as raças e etnias, de modo a que todos os membros de nossa sociedade heterogênea possam ingressar nas instituições de ensino que fornecem o treinamento e a educação necessária ao êxito na América

(...)

(...) a Equal Protection Clause não proíbe que a Escola de Direito utilize a ideia de raça nas decisões de admissão dos estudantes, desde que especificamente concebida para alcançar os benefícios educacionais que [advêm] de um corpo discente plural. 
Note-se que a decisão americana fundou-se na noção de diversidade cultural ou étnica dentro da universidade e não diretamente na ideia de igualdade material que permeou o voto do relator. Talvez por causa disso, o relator diferencie os julgados norte-americanos do caso brasileiro, negando-se a segui-los:

A Constituição brasileira - é importante notar - permite que se faça uma abordagem das políticas afirmativas muito mais abrangente daquela feita pela Suprema Corte dos Estados Unidos. Nos três principais precedentes daquele Tribunal - Bakke v. Regents of the University of California, Gratz v. Bollinger e Grutter v. Bollinger entendeu-se que o uso de critérios étnico-raciais seria constitucional desde que (i) não configurasse reserva de vagas ou o estabelecimento de cotas; e (ii) fossem empregados em conjunto com outros fatores de aferição do mérito.

No Brasil, entretanto, diferentemente do debate que se travou na Suprema Corte daquele país, não há dúvidas, a meu sentir, quanto à constitucionalidade da política de reserva de vagas ou do estabelecimento de cotas nas universidades públicas, visto que a medida encontra amparo no próprio Texto Magno, conforme salientado anteriormente.

Não há como negar que a utilização de precedentes estrangeiros realizada pelo relator foi um tanto quanto contraditória. De início, indicava ele que a jurisprudência americana estava sendo usada como reforço, como demonstração de que a política de cotas era aceita nos Estados Unidos, país com histórico escravocrata, como o Brasil. Posteriormente, ele discorda da conclusão alcançada pela Suprema Corte Americana de que não poderia haver reserva de vagas, mas apenas concessão de pontuação mais vantajosa ao grupo racial eleito como beneficiário da ação afirmativa; e que as ações afirmativas deveriam ser usadas em conjunto com outros critérios de seleção.

Considerando que a jurisprudência americana funda-se na importância da diversidade cultural dentro das universidades americanas, não se baseando diretamente no princípio da igualdade material, como o caso brasileiro, e que os precedentes americanos são muitos mais estritos quanto ao uso de ações afirmativas, refutando inclusive o 
sistema de cotas, pergunta-se qual foi o intento do relator ao recorrer aos casos dos Estados Unidos?

Certamente o caso não buscava um uso positivo do precedente estrangeiro e, ao final, ficou claro que o uso era, na realidade, negativo, ou seja, a posição brasileira afastou-se da perspectiva americana, pois na constituição brasileira haveria dispositivo que permitiria a utilização de cotas para os concursos públicos (art. 37, VII, $\mathrm{CF} / 88$ ), o qual seria, analogamente, aplicável às cotas raciais para entradas nas universidades públicas federais.

Contudo, caso se considere este argumento válido e procedente (da aplicação análoga do dispositivo constitucional), ter-se ia que seria inútil recorrer à jurisprudência americana, pois se estaria diante de textos constitucionais substancialmente diferentes que, neste caso, impediriam a comparação. Em outras palavras, para quê analisar a jurisprudência americana se, de antemão, sabe-se que o texto constitucional brasileiro regulamenta a questão de maneira diversa? Como já dito anteriormente, o texto constitucional é a linha de partida e disso não se pode fugir.

Mesmo que se entenda que o uso foi meramente para ilustrar contrastes, ainda assim, o contraste já seria evidente apenas com base nas diferentes normas constitucionais que regulam o assunto em cada país.

Por fim, caso se considere que os textos constitucionais em comparação são abertos sobre o assunto, não havendo previsão específica sobre o caso das cotas para as universidades públicas e que o assunto demandaria um estudo amplo das premissas de cada ordenamento jurídico em comparação para se ter um uso negativo que permitisse um melhor uma autocompreensão do ordenamento brasileiro, o trabalho do relator deveria ter sido mais detalhado e evidenciado em que circunstâncias o histórico e os valores brasileiros se distanciam dos americanos.

Em outras palavras, quais os fatores que impedem uma conciliação entre as ações afirmativas, a igualdade e a meritocracia no caso brasileiro. Pois não há como negar que entre os três países mencionados neste tópico, Brasil, Índia e Estados Unidos, o Brasil foi aquele em que as ações afirmativas foram adotadas de forma mais intensa e desregulamentada. 
Com efeito, não houve qualquer preocupação em se afastar aqueles que, embora possam pertencer a etnias desfavorecidas, não se enquadram, individualmente, na concepção de pessoas socialmente desfavorecidas, como foi feito na Índia, bem como não houve qualquer preocupação em conjugar as ações afirmativas com a meritocracia (outro aspecto da igualdade), como observado nos Estados Unidos.

Sendo o Brasil um país menos igualitário do que os Estados Unidos e mais igualitário do que a Índia, não se compreende, ao menos, da argumentação do relator, qual foi a real função da menção a experiências estrangeiras para a conclusão do acórdão.

Portanto, exceto pela análise detida dos precedentes americanos mencionados pelo relator, o uso de precedentes estrangeiros neste caso deixou a desejar, pois, em primeiro lugar, deixou de realizar uma salutar interlocução com a experiência indiana e, em segundo lugar, apenas citou a jurisprudência americana de maneira decorativa, não havendo qualquer interlocução, apenas para se dizer que ela é inaplicável, mas não o porquê de ela ser inaplicável ao caso brasileiro. 


\section{CONCLUSÃO}

Neste tópico conclusivo não se buscará apresentar uma lista de conclusões alcançadas no decorrer do trabalho. Assim se objetiva evitar uma repetição e simplificação dos assuntos discutidos nestas páginas. Entende-se que seja mais proveitoso partir das premissas já construídas nos capítulos 1 e 2 , referentes às possibilidades e formas de uso de precedentes estrangeiros, focando-se um pouco mais nos critérios elencados e no método sugerido e, em especial, nas decisões do Supremo Tribunal Federal ora analisadas.

No que concerne aos critérios, ou elementos de conexão, estes integram, sem dúvida, doutrina ainda em construção, com um longo caminho a ser trilhado. Certamente este trabalho apenas lança as primeiras sementes que podem um dia germinar e acabar numa verdadeira metodologia para o uso de precedentes estrangeiros pela jurisdição constitucional.

Com efeito, não há como negar que os critérios apresentados nesta dissertação são sugestões a serem aperfeiçoadas em futuros estudos e por demais estudiosos do tema. Além disso, os critérios apresentados não têm a pretensão de se consubstanciarem em uma lista exaustiva, pelo que a descoberta e o desenvolvimento de outros elementos de conexão são bem-vindos na medida em que permitirão capturar outras formas de interlocução constitucional.

No entanto, a discussão acerca dos critérios e sobre o método para o uso de precedentes estrangeiros, por si só, ainda que inicial, tem o grande mérito de chamar atenção para o uso voluntarioso, ilegítimo e injustificado de precedentes estrangeiros pela jurisdição constitucional.

De fato, a metodologia aqui sugerida, com suas três de etapas (demonstração do elemento de conexão, contextualização e pertinência) visa, por um lado, justamente, acabar com ou, ao menos, minimizar a má-utilização de precedentes estrangeiros (uso equivocado, submisso, ornamental e aleatório) pela jurisdição constitucional e, por outro lado, potencializar o uso no modo dialógico, que, indubitavelmente, pode trazer inúmeros benefícios para a solução de controvérsias constitucionais. 
Para tanto, as fases estabelecidas para alcançar um uso adequado de jurisprudência estrangeira foram fundadas no valor da transparência e na obrigação imposta ao Poder Judiciário de fundamentar todas as suas decisões.

Desta forma, as sugestões aqui desenvolvidas para o uso de precedentes estrangeiros tem uma certeza: todas elas têm que ser implementadas em função da transparência, ou seja, somente o uso transparente de precedentes estrangeiros, no qual esteja claro o contexto e a pertinência da utilização, pode alcançar os requisitos mínimos para a aceitação da ferramenta interpretativa sugerida neste trabalho. Não haverá critério e método que se sustentem sem a dita transparência.

É preciso frisar também que a questão sobre o uso de precedentes estrangeiros e a busca de sua racionalização é uma discussão recente, embora seja uma prática antiga. Esta é uma das grandes polêmicas jurídicas que se tem nos Estados Unidos atualmente e que está começando a surgir, de maneira moderada e mais elaborada, no Canadá e na África do Sul.

No caso brasileiro especificamente, a realidade é ainda mais grave, pois o recurso, pelo Supremo Tribunal Federal, a precedentes estrangeiros tem aumentado progressivamente e não há nem por parte da Corte, nem por parte da doutrina, qualquer preocupação em sistematizar e racionalizar a utilização de precedentes estrangeiros.

Dos acórdãos analisados pode se inferir que, embora haja algumas exceções, o uso é feito majoritariamente de forma aleatória e inconsciente, na maioria das vezes no modo ornamental, sem qualquer preocupação em se apresentar o julgado citado, seu histórico e significado no país de origem. Ademais, desconsideram-se, inúmeras vezes, as circunstâncias fáticas que permearam a decisão constitucional estrangeira invocada. Também, em regra, não há maiores preocupações em se realizar uma verdadeira interlocução constitucional, uma comparação mais refinada. Localizou-se, inclusive, um julgado que faz a utilização equivocada de jurisprudência estrangeira. É uma situação preocupante e que também demonstra certo deslumbramento desmedido com o que vem de fora.

Talvez este deslumbramento explique porque alguns votos apresentam uma profusão julgados estrangeiros que, ao invés de facilitarem a compreensão da decisão, complicam-na. Chama atenção, também, o grande número de citações indiretas, feitas 
por meio de doutrina, sem a consulta da fonte primária. Não há qualquer problema em se recorrer à doutrina estrangeira que analisa julgados de outras jurisdições constitucionais. Mas para utilizar um julgado estrangeiro como um dos fundamentos de uma decisão constitucional doméstica é preciso conhece-lo diretamente para evitar que ele esteja contaminado pela visão de doutrinadores.

Estes dois problemas talvez possam ser resolvidos facilmente, bastando que os ministros optem por citarem menos acórdãos em cada julgado e fazer uma análise mais detidas daqueles que forem selecionados para auxiliar sua argumentação.

Além destes problemas, é altamente perceptível que os precedentes vêm, na sua grande maioria, dos Estados Unidos e da Alemanha. Esta constatação em si não é problemática, pois, certamente, estes países têm muito a oferecer no campo jurídico. Ocorre, todavia, que este uso também pode se dar em decorrência simplesmente da tradição destes sistemas e do deslumbramento que eles causam, gerando, desta feita, comparações inadequadas, isto é, que desconsideram a realidade social e cultural do Brasil.

Por outro lado e, sintomaticamente, há uma grande pobreza de comparações com países vizinhos ou que estejam em mesmo estágio de desenvolvimento que o Brasil. Em que pese a ordem constitucional para que o Brasil se integre à comunidade latinoamericana de nações, a jurisdição constitucional brasileira pouco tem feito, naquilo que lhe é pertinente, para dar efetividade a este comando constitucional, haja vista que rarissimamente são citados precedentes de países latino-americanos. Principalmente no campo das normas programáticas, a comparação com países em desenvolvimento pode vir a ser muito útil.

Outrossim, parece não haver o uso do elemento de conexão genealógico na sua modalidade direta. A interlocução constitucional entre Brasil e Portugal parece ser bastante tímida, podendo se falar em ausência de intercâmbio jurisprudencial justamente em um ambiente onde a língua, a história, os costumes e as tradições podem ser amplamente explorados.

O que também se afere das decisões lidas é que poucas vezes se procede a um uso pragmático de decisões estrangeiras. Não se sabe exatamente a causa desta constatação. Talvez seja porque o Tribunal não tenha tido a oportunidade, talvez seja porque o direito constitucional brasileiro esteja impregnado de interpretações valorativas que impedem 
uma análise mais empírica que pudesse ser realizada com a ajuda das ciências sociais. De qualquer forma, independentemente do motivo, o Supremo Tribunal Federal está perdendo a oportunidade de se utilizar de uma ferramenta extremamente útil em alguns casos difíceis.

Portanto, a conclusão a que se chega é que é preciso, em terras brasileiras, chamar atenção para o uso de precedentes estrangeiros pela jurisdição constitucional de maneira inconsistente e ilegítima, provocando um intenso debate sobre os possíveis critérios e métodos que podem nortear uma utilização salutar de material alienígena pelos juízes constitucionais no controle de constitucionalidade. Eis o que este trabalho pretende ter alcançado. 


\section{BIBLIOGRAFIA}

ACKERMAN, Bruce. The Rise of World Constitutionalism. In: Faculty Scholarship Series Yale Law School Legal Scholarship Repository, Paper 129, 1997, pp.. 771-797.

ADLER, Matthew D. Can Constitutional Borrowing be Justified? A Comment on Tushnet. In: University of Pennsylvania Journal of Constitutional Law, 1998, pp.. 350-357.

ALEXY, Robert. Teoria da Argumentação Jurídica - A Teoria do Discurso Racional como Teoria da Fundamentação Jurídica. $3^{\text {a }}$ Ed. Rio de Janeiro: Forense, 2011.

ALFORD, Roger P. Four Mistakes in the Debate on 'Outsourcing Authority'. In: Albany Law Review, vol. 69, n. 3, 2006, p. 653.

. In search for a Theory for Constitutional Comparativism. In: UCLA Law Review, vol. 52, n. 3, February 2005, pp.. 639-714.^

. Misusing International Sources to Interpret the Constitution. In: American Journal of International Law, vol. 98, n. 57, 2004, pp.. 57-69.

ALLAN, James. Jeremy Waldron and the Philosopher's Stone. In: University of Queensland TC Beirne School of Law Research Paper n. 08-03; San Diego Law Review, Forthcoming. Disponível em SSRN: <http://ssrn.com/abstract=1095532>. Acesso em 06 fev. 2012

ANDERSON, Kenneth. Foreign Law and the U.S. Constitution. In: Policy Review, n. 131, June-July 2005, pp.. 33-50.

ANNUS, Taavi. Comparative Constitutional Reasoning: The Law and Strategy of Selecting the Right Arguments. In: 14 Duke Journal of Comparative \& International Law, 2004, pp.. 301-350.

ÁVILA, Humberto. Neoconstitucionalismo: entre a "Ciência do Direito" e o "Direito da Ciência". In: Revista Brasileira de Direito Público - RBDP: Belo Horizonte, ano 7, n. 23, out. 2008.

$<$ http://www.editoraforum.com.br/bid/bidConteudoShow.aspx?idConteudo=62753>. Acesso em 15 abr. 2010. 
Teoria dos Princípios: da definição à aplicação dos princípios jurídicos. $10^{\mathrm{a}}$ ed. São Paulo: Malheiros, 2009.

BAKER JR., John S. Citing Foreign and international law to interpret the constitution: what's the point?. In: Albany Law Review, vol. 69, n. 3, June 2006.

BARAK, Aharon. Response to The Judge as Comparatist: Comparison in Public Law. In: Faculty Scholarship Series. Paper 369, 2005, pp.. 195-202.

BASNET, Gyan. A Critical Approach to the Study of Constitutional Migration. In: Cambridge Student Law Review, vol. 4, n. 1, 2008, pp.. 40-53.

BASTOS JR, Luiz Magno Pinto. Utilización del derecho constitucional comparado en la interpretación constitucional: nuevos retos a la teoría constitucional. In: Revista Peruana de Derecho Publico, v. 8, 2007, pp.. 79-108.

BAUDENBACHER, Carl. Judicial Globalization: New Development or Old Wine in New Bottles?. In Texas International Law Journal 2003, p. 505. Disponível em: $<$ http://www.tilj.org/content/journal/38/num3/Baudenbacher505.pdf $>$. Acesso em 28 mai. 2011.

BOBBIO, Norberto. A Era dos direitos. Trad. Carlos Nelson Coutinho. Rio de Janeiro: Campus, 1992.

. Direito e Poder. São Paulo: Editora UNESP, 2008.

. O positivismo jurídico: lições de filosofia do direito. São Paulo: Ícone, 2006.

BODANSKY, Daniel M. The Use of International Sources in Constitutional Opinion. Scholarly Works. Paper 207, 2004. Georgia Law Digital Commons. Disponível em <http://digitalcommons.law.uga.edu/fac_artchop/207>. Acesso em 19 mar. 2011.

BÖHMER, Martin. Borrowings and Acquisitions: The Use of Foreign Law as a Strategy to build Constitutional and Democratic Authority. In: Seminario en Latinoamérica de Teoría Constitucional y Política, Panel 3, Hybrid Legal Cultures: Borrowings and Impositions Papers (14/06/2007), San Juan, Porto Rico, Yale Law School, 2007. Disponível em: $<$ http://www.law.yale.edu/documents/pdf/sela/MartinBohmer_English_pdf $>$. Acesso em 18 maio 2011. 
BOMHOFF, Jacco. Balancing, the Global and the Local: Judicial Balancing as a Problematic Topic in Comparative (Constitutional) Law. In: Hastings International and Comparative Law Review, vol. 31, n. 2, 2008.

BORK, Robert H. A Country I Do Not Recognize: The Legal Assault On American Values. Stanford: Hoover Institution Press, 2005.

BOTHA, Henk. Comparative law and constitutional adjudication: A South African perspective. In: Jahrbuch des öffentlichen Rechts der Gegenwart, Band 5, 2007, pp.. 569-598.

BUYS, Cindy G. Burying Our Constitution in the Sand?: Evaluating the Ostrich Response to the Use of International and Foreign Law in U.S. Constitutional Interpretation. In: Bepress Legal Series, Paper 1094, 2006.

CALABRESI, Steven and ZIMDAHL Stephanie Dotson. The Supreme Court and Foreign Sources of Law: Two Hundred Years of Practice and The Juvenile Death Penalty Decision. In 47 William \& Mary Law Review (Wm. \& Mary L. Rev.), 2005, p. 743.

CANOTILHO, J. J. Gomes. Direito constitucional e Teoria da Constituição. Coimbra: Almedina, 2000.

CARDOSO, Gustavo Vitorino. O Direito Comparado na Jurisdição Constitucional. In: Revista Direito GV São Paulo, 6(2), Jul/Dez 2010, pp.. 469-492.

CAROLAN, Bruce. The Search for Coherence in the Use of Foreign Court Judgements by the Supreme Court of Ireland. In: Tulsa Journal of Comparative \& International Law, vol 12-1, 2004, pp.. 123-148.

CAROZZA, Paolo G. 'My Friend is a Stranger': The Death Penalty and the Global Ius Commune of Human Rights. In: Texas Law Review, vol. 81, 2003, p. 1031.

CEIA, Eleonora Mesquita. Tratados Internacionais e constituições nacionais na jurisprudência constitucional do Brasil e da Europa. In: Direito e Relações Internacionais. Seminário da Conferência Internacional da ILSA - Brasil 2008, realizado de 13 a 16 de agosto de 2008, em Belo Horizonte, Brasil. Disponível em: <http://gedi.objectis.net/eventos1/ilsabrasil2008/artigos/deri/mesquitaceia.pdf.> Acesso em 16 ago. 2009. 
CHOUDHRY, Sujit. Globalization in Search of Justification: Toward a Theory of Comparative Constitutional Interpretation. In: Indiana Law Journal, vol. 74, n. 3, 1999, pp.. 819-892.

Migration as a New Metaphor in Comparative Constitutional Law. In: The Migration of Constitutional Ideas. Cambridge: Cambridge University Press, 2006.

. The Lochner Era and Comparative Constitutionalism. In University of Toronto, Public Law Research Paper n. 02-22. Disponível em: <http://ssrn.com/abstract=363220> or $<$ http://dx.doi.org/10.2139/ssrn.363220>. Acesso em 15 jan. 2011.

CLÈVE, Clemerson Merlin. Direito Constitucional, Novos Paradigmas, Constituição Global e Processos de Integração. In: Revista Trimestral de Direito Civil, vol. 39, 2002, pp.. 23-32.

CONI, Luis Cláudio. A internacionalização do Poder Constituinte. Porto Alegre: Sergio Antonio Fabris Editor, 2006.

Diplomacia Judicial. Disponível em: $<$ http://www2.stf.jus.br/portalStfInternacional/cms/destaquesNewsletter.php?sigla=newsletter PortalInternacionalFoco\&idConteudo=217832>. Acesso em 20 nov. 2012.

CORTE INTERAMERICANA DE DIREITOS HUMANOS (CIDH), Opinión Consultiva OC18/03 de 17 de septiembre de 2003, solicitada por los Estados Unidos Mexicanos, sobre la condición jurídica y derechos de los migrantes indocumentados.

DAMMANN, Jens. The Role of Comparative Law in Statutory and Constitutional Interpretation. In: St. Thomas Law Review, vol. 14, 2002, p. 513.

DELMAS-MARTY, Mireille. Les forces imaginantes $d u$ droit: Le Relatif et Le Universel. Paris: Seuil, 2004. . Le forces imaginante du droit (II): Le pluralisme ordonné. Paris: Seuil, 2006.

DE VERGOTTINI, Giuseppe. Más allá del diálogo entre tribunales - Comparación y relación entre jurisdicciones. $1^{\text {a }}$ Ed. Pamplona, Espanha: Thompson Reuters, 2010.

DIMOULIS, Dimitri; MARTINS, Leonardo. Teoria Geral dos Direitos Fundamentais. $2^{\mathrm{a}}$ ed. São Paulo: Revista dos Tribunais, 2009. 
DIXON, Rosalind and GINSBURG, Tom. Introduction. In: Comparative Constitucional Law. Edward Elgar Publishing, 2011; University of Chicago, Public Law Working Paper n. 362.

DIXON, Rosalind and POSNER, Eric A. The Limits of Constitutional Convergence September 15, 2010. University of Chicago, Public Law Working Paper n. 329. Disponível em: <http://ssrn.com/abstract=1677634> or $<$ http://dx.doi.org/10.2139/ssrn.1677634>. Acesso em 15 jun. 2012.

DOLINGER, Jacob. Direito Internacional Privado - Parte Geral. 55 ${ }^{\text {a }}$ Ed. Rio de Janeiro: Renovar, 1997.

DWORKIN, Ronald. Levando os direitos a sério. São Paulo: Martins Fontes, 2002.

EPSTEIN, Lee and KNIGHT, Jack. Constitutional Borrowing and nonborrowing. In I-CON: International Journal of Constitutional Law 1, 2003, pp.. 196-223.

EWALD, William B. Comparative Jurisprudence (II): The Logic of Legal Transplants. In: American Journal of Comparative Law, vol. 43, 1995, pp.. 489-510.

FERRAZ JÚNIOR, Tércio Sampaio. Introdução ao Estudo do Direito. $4^{\mathrm{a}}$ ed., São Paulo: Atlas, 2003.

. Limites da Interpretação Jurídica. In: Revista Brasileira de Filosofia, vol. 232, jan/jun 2009.

FERRAZ JÚNIOR, Tércio Sampaio e MARANHÃO. Função Pragmática da Justiça na Hermenêutica Jurídica: lógica do ou no Direito? Disponível em: $<$ http://www.sampaioferraz.com.br/images/Funcao_Pragmatica.pdf. $>$ Acesso em 15 jul. 2011. FIGUEIREDO, Marcelo. Notas a respeito da utilização de jurisprudência estrangeira pelo Supremo Tribunal Federal no Brasil. In: Biblioteca Digital Revista Brasileira de Estudos Constitucionais, Belo Horizonte, n. 12, ano 3, Outubro 2009.

FINE, Toni M. O judiciário americano e o direito internacional: o novo debate. In: Biblioteca Digital Revista Brasileira de Estudos Constitucionais, Belo Horizonte, n. 12, ano 3, Outubro 2009. Disponível em: <http://www.bidforum.com.br/bid/PDI0006.aspx?pdiCntd=65600>. Acesso em 30 mai. 2011. 
FONTANA, David. Refined Comparativism in Constitutional Law. In: UCLA Law Review, vol. 49, 2001, p. 539.

. The Next Generation of Transnational/Domestic Constitutional Law Scholarship: A Reply to Professor Tushnet. In: Loyola of Los Angeles Law Review, vol. XX, 2005, pp.. 110139.

. The Rise and Fall of Comparative Constitutional Law in the Postwar Era. In: Yale Journal of International Law, vol. 36, 2011, p. 1.

FRANKENBERG, Günter. Constitutional Transfer: The IKEA Theory Revisited. In International Journal of Constitutional Law, vol 8, n. 3, 2010, pp.. 563-579.

FRISCHEISEN, Luiza Cristina Fonseca; GARCIA, Monica Nicida e GUSMAN, Fábio. Execução Provisória da Pena - Panorama nos ordenamentos nacional e estrangeiro. Disponível em: $\quad$ http://2ccr.pgr.mpf.gov.br/coordenacao/eventos/execucao-dapena/3_execucao_provisoria_da_pena_versao_final_corrigido2.pdf. Acesso em 13 out. 2012.

GELTER, Martin and SIEMS, Mathias M. Language, Legal Origins, and Culture before the Courts: Cross-Citations between Supreme Courts in Europe. November 21, 2010. In: Supreme Court Economic Review, vol. 21, 2013. Disponível em: <http://ssrn.com/abstract=1719183 $>$. Acesso em 12 nov. 2012. and Networks, Dialogue or One-Way Traffic? An Empirical Analysis of Cross-Citations between Ten of Europe's Highest Courts. March 22, 2011. In: Maastricht European Private Law Institute (M-EPLI) Working Paper n. 2011/03. Disponível em: $<$ http://ssrn.com/abstract=1722721 >. Acesso em 12 nov. 2012.

GINSBURG. Ruth Bader. A decent Respect to the Opinions of [Human]kind: The Value of a Comparative Perspective in Constitutional Adjudication. In: Cambridge Law Journal, 64(3), November 2005, pp.. 575-592.

GLENDON, Mary Ann. Judicial Tourism: What's wrong with the U.S. Supreme Court citing foreign law. Disponível em: <http://www.law.harvard.edu/news/2005/09/16_glendon.html>. Acesso em 15 ago. 2012.

GLENSY, Rex D. Which Countries Count? Lawrence v. Texas and the Selection of Foreign Persuasive Authority. In: Virginia Journal of International Law, vol. 45, 2005, pp.. 357-449. 
GOLDSWORTHY, Jeffrey. Questioning the migration of constitutional ideas: rights, constitutionalism and the limits of convergence. In: CHOUDHRY, Sujit (coord.). The Migration of Constitutional Ideas. Cambridge University Press, 2007. Cambridge Books Online.

GRAY, David C. Why Justice Scalia should be a Constitutional Comparativist sometimes. In: Stanford Law Review, vol. 59, Issue 5, 2007, pp.. 1249-1289.

GRAZIADEI, Michele. Legal Transplants and the frontiers of Legal Knowledge. In: Theoretical Inquiries in Law, vol. 10, Issue 2, June 2009, pp.. 723-743, ISSN (Online) 15653404, DOI: 10.2202/1565-3404.1231.

GUIMARÃES, Ariane Costa; SILVA, Christine Oliveira Peter da. A utilização do método comparativo pelo Supremo Tribunal Federal. Direito Público (Porto Alegre), v. 30, 2009, pp.. 198-211.

HÄBERLE, Peter. Estado Constitucional Cooperativo. Trad. de Marcos Augusto Malisca e Elisete Antoniuk. Rio de Janeiro: Renovar, 2007.

HALMAI, Gábor. The use of foreign law in constitutional interpretation. In: ROSENFELD, Michel and SAJÓ, András. The Oxford Handbook of Comparative Constitutional Law. Oxford: Oxford Handbooks in Law, 2012.

HARDING, Sarah K. Comparative Reasoning and Judicial Review. In: Yale Journal of International Law, n. 28, 2003, pp.. 409-464.

HIRSCHL, Ran. Comparative Constitutional Law: Thoughts on Substance and Method. In: Indian Journal of Constitutional Law 2, 2008, pp.. 11-37.

. On the blurred methodological matrix of comparative law. In: CHOUDHRY, Sujit (coord). The Migration of Constitutional Ideas. Cambridge: Cambridge University Press, 2007. Cambridge Books Online.

The Question of Case Selection in Comparative Constitutional Law. In: American Journal of Comparative Law, vol. 53, n. 1, pp.. 125-155, Winter 2005; University of Toronto, Legal Studies Research Paper n. 901700. 
HORBACH, Carlos Bastide. A Roupa Nova do Direito Constitucional: neoconstitucionalismo, pós-positivismo e outros modismos. In: Revista dos Tribunais (São Paulo), v. 859, p. 81-91, 2007.

Referências estrangeiras são constante no STF. Disponível em: http://www.conjur.com.br/2012-nov-10/observatorio-constitucional-referencias-estrangeirassao-constante-stf. Acesso em 10 nov. 2012

JACKSON, Vicki C. Constitutions as "Living Trees"? Comparative Constitutional Law and Interpretive Metaphors. In: Fordham Law Review, n. 75, 2006, pp.. 921-960.

. Constitutional Comparisons: Convergence, Resistance, Engagement. In: Harvard Law Review, vol. 119, n. 1, Nov., 2005 pp.. 109-128.

. Methodological Challenges in Comparative Constitutional Law. In: Georgetown Public Law and Legal Theory Research, Paper n. 11-11, 2010, pp.. 319-326.

JACOBSON, Gary Jeffrey. The Permeability of Constitution Borders. In: Texas Law Review, vol. 182, 2004, pp.. 1762-1818.

KAHN, Paul W. Comparative Constitutionalism in a New Key. In: Michigan Law Review (Yale Law School Legal Scholarship Repository), vol. 101, 2004, pp.. 2677-2705.

KAHN-FREUND, Otto. On Uses and Misuses of Comparative Law. In: The Modern Law Review, 37(1), 1974, pp.. 1-27.

KELSEN, Hans. Teoria Geral do Direito e do Estado. São Paulo: Martins Fontes, 1998. . Teoria pura do direito. São Paulo: Martins Fontes, 2000.

KERSCH, Ken I. The New Legal Transnationalism, the Globalized Judiciary, and the Rule of Law, In: Washington University Global Studies Law Review 4, 2005, pp.. 345-387.

KLUG, Heinz. Model and Anti-Model: The United States Constitution and the "Rise of World Constitutionalism". In: Wisconsin Law Review, 2000, p. 597.

$\mathrm{KOH}$, Harold Hongju. International Law as Part of Our Law. Faculty Scholarship Series. Paper 1782, 2004. Disponível em: <http://digitalcommons.law.yale.edu/fss_papers/1782> Acesso em 10 mar. 2010. 
International Law as Part of Our Law. In: Yale Law School Legal Scholarship Repository - Faculty Scholarship Series, Paper 1782, 2004, pp.. 44-57.

. The Globalization of Freedom. In: 26 Yale Journal of International Law, 2001, pp.. 305-312.

KONTOROVICH, Eugene. Disrespecting the 'Opinions of Mankind: International Law in Constitutional Interpretation. In: Public Law and Legal Theory Working Papers (University of Chicago), vol. 8, 2005, pp.. 261-268.

KREIMER, Seth F. Invidious Comparisons: Some Cautionary Remarks on the Process of Constitutional Borrowing. In: 1 University of Pennsylvania Journal of Constitutional Law, 1999, pp.. 640-650.

KUHNER, Timothy K. The Foreign Source Doctrine: Explaining the Role of Foreign and International Law in Interpreting the Constitution. In: University of Cincinnati Law Review, vol. 75, 2007, pp.. 1389-1450.

LAFER, Celso. Declaração Universal dos Direitos Humanos (1948). In: MAGNOLI, Demétrio. A história da paz. São Paulo: Contexto, 2008, pp.. 297-330.

LARSEN, Joan L. Importing Constitutional Norms from a "Wider Civilization": Lawrence and the Rehnquist Court's Use of Foreign and International Law in Domestic Constitutional Interpretation. In: Ohio Law State Journal, vol. 65, 2004, pp.. 1282-1327.

LEAL, Roger Stiefelmann. A convergência dos sistemas de controle de constitucionalidade: aspectos processuais e institucionais. In: Revista de Direito Constitucional e Internacional, vol. 57, 2006, pp.. 62-81.

LEAL, Saul Tourinho. As Consequências de um novo Supremo. In: Observatório da Jurisdição Constitucional, Ano 2, Outubro 2008. Disponível em: $<$ <ttp://ojs.idp.edu.br/index.php/observatorio/article/view/8/7>. Acesso em 13 set. 2009.

LEGRAND, Pierre. The impossibility of Legal Transplants. In: 4 Maastricht Journal of European \& Comparative Law, p. 111, 1997.

The same and the different. In: ; MUNDAY, Roderick (orgs.). Comparative Legal Studies: Traditions and Transitions. pp.. 240-311. Cambridge: Cambridge University 
Press, 2003. Cambridge Books Online. Disponível em: <http://dx.doi.org/10.1017/CBO9780511522260.009>. Acesso em 10 set. 2012.

LEVINSON, Sanford V. Looking Abroad When Interpreting the U.S. Constitution: Some Reflections [Symposium: Globalization and the Judiciary]. In: 39 Texas International Law Journal, 2004, p. 353.

LOLLINI, Andrea. Legal Argumentation Based on Foreign Law: An Example from Case Law of the South African Constitutional Court. In: Utrecht Law Review, vol. 3, n. 1, June 2007pp.. 60-74.

MAGALHÃES, José Carlos de. O Supremo Tribunal Federal e o direito internacional: uma análise crítica. Porto Alegre: Livraria do Advogado, 2000.

MARKESINIS, Basil. National Selfsufficiency or Intellectual Arrogance? The current attitude of American Courts towards foreign law. In: The Cambridge Law Journal, 65, 2006.

MARKESINIS, Basil and FEDTKE, Jörg. The Judge as Comparatist. In: 80 Tulane Law Review, November 2005, p. 11.

MARKOVITS, Richard S. Learning from the Foreigners: A Response to Justice Scalia's and Professor Levinson's Professional Moral Parochialism [Symposium: Globalization and the Judiciary]. In: 39 Texas International Law Journal, 2004, p. 367.

MARTINICO, Giuseppe. Judging in the Multilevel Legal Order: Exploring the Techniques of 'Hidden Dialogue'. In: King's Law Journal, n. 21.2, 2010, pp.. 257-281.

MCCRUDDEN, Christopher. Judicial Comparativism and Human Rights. In: Oxford Legal Studies Research Paper Series, n. 29/2007, pp.. 371-398.

MCGINNIS, John O. Contemporary foreign and international law in constitutional construction. In: Albany Law Review, vol. 69, 2006, pp.. 801-808.

MENDES, Gilmar Ferreira. A justiça constitucional nos contextos supranacionais. In: Direito Público, Porto Alegre, vol. 2, n. 8, 2005, pp.. 54-91.

MENDES, Gilmar Ferreira; COELHO, Inocêncio Martires; e BRANCO, Paulo Gustavo Gonet. Curso de Direito Constitucional. $4^{\mathrm{a}}$ ed. São Paulo: Saraiva, 2009. 
MENDES, Gilmar Ferreira, e VALE, André Rufino. A influência do pensamento de Peter Häberle no STF. In: Observatório da Jurisdição Constitucional, IDP, Ano 2, 2008/2009, Brasília. Também disponível em: $<$ http://ojs.idp.edu.br/index.php/observatorio/article/viewFile/205/173>. Acesso em 16 ago. 2009.

MONTORO, Franco. Filosofia do Direito e Colonialismo Cultural. In: Revista de Informação Legislativa, Brasília: Senado Federal, Ano X, n. 37, jan/mar, 1973, pp.. 4-20.

MOON, Cody. Comparative Constitutional Analysis: Should the United States Supreme Court Join the Dialogue?. In: 12 Washington University Journal of Law \& Policy, 2003, p. 229.

MORALES, Cesar Mecchi. Originalismo e interpretação constitucional. Tese de Doutorado, FD/USP, 2011

NEVES, Marcelo. Transconstitucionalismo. São Paulo: Martins Fontes, 2009.

PAGLIARINI, Alexandre Coutinho. Constituição Supranacional: uma internacionalização do Direito Constitucional. In: Revista Direitos Fundamentais e Democracia, vol 5/2009. Disponível em: $<$ http://revistaeletronicardfd.unibrasil.com.br/index.php/rdfd/article/viewPDF>. Acesso em 7 jun. 2010.

PARRISH, Austen L. Storm in a Teacup: The U.S. Supreme Court's Use of Foreign Law. In: University of Illinois Law Review, vol. 2, 2007, pp.. 637-680.

PEGORARO, Lúcio. Derecho Constitucional y método comparativo. Disponível em: http://biblio.juridicas.unam.mx/libros/4/1793/6.pdf. Acesso em 12 abr. 2012.

PERJU, Vlad. Comparative Constitutionalism and the Making of A New World Order. In: Constellations 12, 2005, pp.. 464-486. Disponível em:

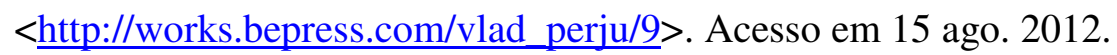

. Constitutional Transplants, Borrowing, and Migrations. In: Boston College Law School Faculty Papers. Paper 360, 2012.

Cosmopolitanism and Constitutional Self-Government. In: (I-CON), International Journal of Constitutional Law. Forthcoming; Boston College Law School Legal Studies 
Research Paper n. 201. Disponível em: <http://ssrn.com/abstract=1647069>. Acesso em 15 ago. 2012.

. Provocations: Law's Republics. Forthcoming, 125 Harvard Law Review Forum, June 2012; Boston College Law School Legal Studies Research Paper n. 270. Disponível em: $<$ http://ssrn.com/abstract=2083611 >. Acesso em 15 ago. 2012.

. The Puzzling Parameters of the Foreign Law Debate. In: Utah Law Review, 2007, pp.. $167-214$

PFERSMANN, Otto. Le droit comparé comme interprétation et comme théorie du droit. In: Revue internationale de droit compare, vol. 53 n. 2, Avril-Juin 2001. pp.. 275-288.

PINHO, Rodrigo Bossi de. A aplicação analógica da Lei Maria da Penha. In Revista da EMERJ, v. 12, $\mathrm{n}^{\circ}$ 46, 2009, p. 308. Disponível em: http://www.emerj.rj.gov.br/revistaemerj online/edicoes/revista46/Revista46 305.pdf. Acesso em 20 set. 2012

POSNER, Richard A. No Thanks, We Already Have Our Own Laws: The Court Should Never View a Foreign Legal Decision as a Precedent in Any Way. In: Legal Affairs, July/August 2004, p. 40.

RAALF, Matthew S. A Sheep in Wolf's Clothing: Why the Debate Surrounding Comparative Constitutional Law Is Spectacularly Ordinary. In: Fordham Law Review, vol. 73, Issue 3, Article 16, 2004, pp.. 1239-1288.

RAMOS, André de Carvalho. O Diálogo das Cortes: O Supremo Tribunal Federal e a Corte Interamericana de Direito. In: AMARAL JÚNIOR, Alberto; JUBILUT, Liliana Lyra (orgs.). $O$ STF e o Direito Internacional dos Direitos Humanos. São Paulo: Quartier Latin, 2009, pp.. 805-850.

. Processo Internacional dos Direitos Humanos. São Paulo: Renovar, 2002.

RAMOS, Elival da Silva. Ativismo Judicial: Parâmetros Dogmáticos. São Paulo: Saraiva, 2010. 
RAMSEY, Michael D. International Materials and Domestic Rights: Reflections on Atkins and Lawrence. In: The American Journal of International Law, vol. 98, n. 1, Jan. 2004, pp.. 69-82.

RODRIGUES JUNIOR, Otavio Luiz. Fonte estrangeira pode fundamentar decisão nacional?. Disponível em: http://www.conjur.com.br/2012-dez-12/direito-comparado-recursoestrangeiro-fundamentar-decisao-nacional. Acesso em 12 dez. 2012.

- Problemas na importação de conceitos jurídicos. Disponível em: http://www.conjur.com.br/2012-ago-08/direito-comparado-inadequada-importacao-institutosjuridicos-pais. Acesso em 8 ago. 2012.

ROSENFELD, Michel. Constitutional Migration and the bounds of comparative analysis. In: 58 New York University Annual Survey of American Law, pp.. 67-84, 2001.

. Principle or Ideology? A Comparativist Perspective on the U.S. Controversy Over Supreme Court Citations to Foreign Authorities. In: Cardozo Law School Legal Studies Research Paper n. 213, 2008. Disponível em <http://ssrn.com/abstract=1081854>. Acesso em 15 ago. 2012.

SALDANHA JR., César. Direito Constitucional, Direito Ordinário, Direito Judiciário. In: Cadernos de Pós-Graduação em Direito - PP.GDir/UFRGS, n. III, março 2005, pp.. 07-17.

SCHAUER, Frederick. Authority and Authorities. In: Virginia Law Review, Forthcoming, 2008. Disponível em: <http://ssrn.com/abstract=1143343>. Acesso em 21 fev. 2012.

Constitutional Invocations. In: Fordham Law Review: Vol. 65, Issue 4, 1997, pp. 1295-1312.

. On the Migration of Constitutional Ideas. In: 37 Connecticut Law Review, Summer 2005, pp.. 907-919.

SCHEPPELE, Kim Lane. The Migration of Anti-Constitutional Ideas: The Post-9/11 Globalization of Public Law and the International State of Emergency. In: CHOUDHRY, Sujit. The Migration of Constitucional Ideas. Cambridge: Cambridge University Press, 2006.

SCHNEIDERMAN, David. Exchanging Constitutions: Constitutional Bricolage in Canada. In: Osgoode Hall Law Journal, vol. 40, n. 3\&4, 2002, pp.. 401-424. 
SCHROTH, Ulrich. Hermenêutica Filosófica e Jurídica. In: KAUFMANN, Arthur; HASSEMER, Winfried (org.). Introdução à Filosofia do Direito e à Teoria do Direito Contemporâneas. Lisboa: Calouste Gulbenkian, 2002.

SILVA, Guilherme Amorim Campos da. O uso de precedente estrangeiro pela Justiça Constitucional: Uma Teoria de Unificação do Direito Constitucional Material. Tese de Doutorado, PUC/SP, 2010.

SILVA, José Afonso da. Curso de direito constitucional positivo. 22. a ed. São Paulo: Malheiros, 2003.

. Direito Constitucional Comparado e Processo de Reforma do Estado. Disponível em: http://biblio.juridicas.unam.mx/libros/4/1793/14.pdf. Acesso em 15 mai. 2012, pp. 265-292.

SILVA, Virgílio Afonso da. Direitos fundamentais e relações entre particulares. In: Revista de Direito GV, v.1, n. 1, maio 2005, pp.. 173-180.

. Integração e diálogo constitucional na América do Sul. In: PIOVESAN, Flavia; VON BOGDANDY, Armin; ANTONIAZZI, Mariela Morales. (Orgs.). Direitos humanos, democracia e integração jurídica na América do Sul. Rio de Janeiro: Lumen Juris, v. 1, 2010, pp.. 515-530.

. Interpretação constitucional e sincretismo metodológico. In: (Org.). Interpretação constitucional. São Paulo: Malheiros, 2005, pp.. 115-143.

O conteúdo essencial dos direitos humanos fundamentais e a eficácia das normas constitucionais. In: Revista de Direito do Estado, Ano 1, n. 4, out/dez 2006. Rio de Janeira: Renovar, 2006, pp.. 23-52.

SITARAMAN, Ganesh. The Use and Abuse of Foreign Law in Constitutional Interpretation. In: Harvard Law School Faculty Scholarship Series: Paper 23, 2008. Disponível em:

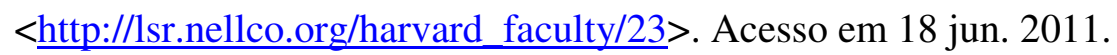

SLAUGHTER, Anne-Marie. A Global Community of Courts. In: Harvard International Law Journal, vol. 44, n. 1, Winter 2003, pp.. 191-219.

A Typology of Transjudicial Communication. In: 29 University of Richmond Law Review, Winter 1994, pp.. 99-137. 
Judicial Globalization. In: 40 Virginia Journal of International Law, 1999-2000, pp.. 1103-1124.

SLAUGHTER, Anne-Marie; BURKE-WHITE, William. An International Constitutional Moment. In: Harvard International Law Journal, vol. 43, n. 1, Winter 2002, pp.. 2-21.

SPECTOR, Horacio. Constitutional Transplants and the Mutation Effect. In: Chicago-Kent Law Review, vol. 83, n. 1, 2008, pp.. 129-145.

STONE, Adrienne. Comparativism in Constitutional Interpretation. In: New Zealand Law Review, pp.. 45-68, 2009; Univ. of Melbourne Legal Studies Research Paper n. 496. September 27, 2010.

SUNSTEIN, Cass R. A Constitution of many minds: Why the Founding Document's Doesn't Mean What It Meant Before. New Jersey: Princeton, 2009.

SUNSTEIN, Cass R. \& POSNER Eric. Response - On Learning From Others. In: 59 Stanford Law Review, 2007, pp.. 1309-1314. $\&$ The Law of Other States. In: 59 Stanford Law Review, 2006, p. 131.

TAVARES, Ana Lúcia de Lyra. Contribuição do Direito Comparado às fontes do Direito Brasileiro. Disponível em:

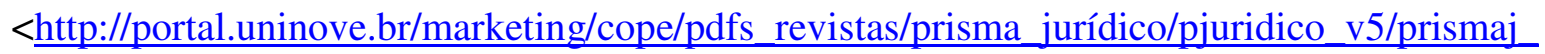
v5_3b19.pdf> Acesso em 15 out. 2009.

TAVARES, André Ramos. Modelos de uso da jurisprudência constitucional estrangeira pela justiça constitucional. In: Biblioteca Digital Revista Brasileira de Estudos Constitucionais. Belo Horizonte: n. 12, ano 3, Outubro 2009. Disponível em: $<$ http://www.bidforum.com.br/bid/PDI0006.aspx?pdiCntd=65598>. Acesso em: 24 maio 2011.

TEITEL, Ruti G. Comparative Constitutional Law in a Global Age. 117 Harvard Law Review, 2004, pp.. 2570-2596.

TEUBNER, Gunther. Legal Irritants: Good Faith in British Law or How Unifying Law Ends up in New Divergences. In: The Modern Law Review, vol. 61, n. 1, jan. 1998, pp.. 11-32. 
TUSHNET, Mark. Interpreting Constitutions Comparatively: Some Cautionary Notes, with Reference to Affirmative Action. In: Georgetown Law Faculty Publications and Other Works. Paper 229, 2004.

. Referring to Foreign Law in Constitutional Interpretation: An Episode in the Culture Wars. In: Baltimore Law Review, n. 35, 2006, pp.. 299-312.

. Returning with Interest: Observations on Some Putative Benefits of Studying Comparative Constitutional Law. In: University of Pennsylvania Journal of Constitutional Law, pp. 325 - 349, 1998.

Some reflections on method in comparative constitutional law. In: SUJIT, Choudhry (coord.). The Migration of Constitutional Ideas. Cambridge: Cambridge University Press, 2007. Cambridge Books Online.

. The Inevitable Globalization of Constitutional Law. In: Harvard Law School: Public Law \& Legal Theory Working Paper Series: n. 09-06, December 18, 2008.

. The Possibilities of Comparative Constitutional Law. In: 108 Yale Law Journal, 1999, p. 1225.

. Transnational/Domestic Constitutional Law. In: 37 Loyola of Los Angeles Law Review, pp. 239-270, 2003.

When Is Knowing Less Better than Knowing More? Unpacking the Controversy over Supreme Court Reference to Non-U.S. Law. In: Minnesota Law Review, n. 90, 2006, pp.. 1275-1306.

VALCKE, Catherine. Comparative Law as Comparative Jurisprudence - The Comparability of Legal Systems, March 2003. Disponível em: <http://ssrn.com/abstract=385861> ou $<$ http://dx.doi.org/10.2139/ssrn.385861>. Acesso em 15 ago. 2012.

VALE, André Rufino do. Aspectos do Neoconstitucionalismo. In: Revista Brasileira de Direito Constitucional - RBDC, n. 09. jan/jun. 2007, pp.. 67-77. Disponível em: <http://www.esdc.com.br/RBDC/RBDC-09/RBDC-09-067-Andre_Rufino_do_Vale.pdf.>. Acesso em 06 out. 2009. 
. Intercâmbio e cooperação internacional entre órgãos de Jurisdição Constitucional. In: Observatório da Jurisdição Constitucional, IDP. P. 01-06, Ano 2008/2009. Disponível em: $<$ http://www.portaldeperiodicos.idp.edu.br/index.php/observatorio/article/viewFile/176/147>. Acesso em 10 set. 2011.

VESPAZIANI, Alberto. Comparison, Translation and the Making of a Common European Constitutional Culture. 9 German Law Journal, 2008, pp.. 547-574. Disponível em: http://www.germanlawjournal.com/index.php?pageID=11\&artID=955. Acesso em 12 jul. 2011.

WALDRON, Jeremy. Foreign Law and the Modern 'Ius Gentium'. In: Harvard Law Review, vol. 119, n. 1, Nov. 2005, pp.. 129-147.

WATSON, Alan. Legal Transplants and European Private Law. In: 4.4 Eletronic Journal of Comparative Law. December 2000, <http://www.ejcl.org/ejcl/44/44-2.html>. Acesso em 10 jul. 2012.

WEINRIB, Lorraine. The postwar paradigm and American exceptionalism. In: CHOUDHRY, Sujit (coord.). The Migration of Constitutional Ideas. Cambridge: Cambridge University Press, 2007. Cambridge Books Online.

WEXLER, Stephen and RAMIREZ ESPINOSA, Naayeli. Is there an exit from the methodological labyrinth in the field of Comparative Constitutional Law? Workshop apresentado no VIII Congresso Mundial de Direito Constitucional de 2010 - México Disponível em: <http://www.juridicas.unam.mx/wccl/ponencias/17/311.pdf>. Acesso em 10 ago. 2012.

WHYTOCK, Christopher A. Foreign Law in Domestic Courts: Different Uses, Different Implications. In: JACKSON, Donald W.; TOLLEY, Michael C.; VOLCANSEK, Mary L. Globalizing Justice: Critical Perspectives on Transnational Law and Cross-Border Migration of Legal Norms. Albany: State University of New York Press, 2010, Chapter 3, pp.. 45-63.

YOUNG, Ernest A. Foreign Law and the Denominator Problem. In: 119 Harvard Law Review, 2005, pp.. 148-167.

. The Trouble With Global Constitutionalism. In: 38 Texas International Law Journal, 2003, pp.. 527-545. 
ZEHNDER, Jacob J. Constitutional Comparativism: The Emerging Risk of Comparative Law as a Constitutional Tiebreaker. In: Valparaiso University Law Review, vol. 41, n. 4, 2007, pp.. 1739-1788.

ZOETHOUT, Carla M. The Dilemma of Constitutional Comparativism or the Legitimacy of Reference to Foreign Law - VIII Congresso Mundial de Direito Constitucional de 2010 México. Disponível em: <https://www.juridicas.unam.mx/wccl/ponencias/15/345.pdf>. Acesso em 15 de ago. 2012. 